Victoria University of Wellington

New Zealand School of Music

\title{
Mythological Signification in Smetana's Tábor and Blaník and its Implications on Personal Compositional Output
}

\author{
Exegesis and Compositional Portfolio \\ Presented in Fulfillment of the Requirements for the course \\ NZSM 598 Composition \\ Partial Fulfillment of the Requirements for the degree \\ Master of Musical Arts \\ in Instrumental/Vocal Composition
}

James A. Skierka

VUW ID: C300326292

Under the Supervision of Michael Norris

April 1, 2016 



\section{Table of Contents}

I. Mythological Signification in Smetana's Tábor and Blaník

1. Introduction 1

2. Defining Literary Narrative and the Source Material 2

3. Representation of Literary Narrative in $19^{\text {th }}$ Century Compositions 4

4. Approach to the Analysis 5

4.1 Analysis of Tábor $\quad 6$

4.2 Analysis of Blanik 12

4.3 Conclusions to Draw from Tábor and Blaník 16

5. Application to my own Compositions 17

5.1 Analysis of Janus habet finem 17

5.2 Analysis of Crane and Otter 18

5.3 Analysis of Un trajet intérieur $\quad 20$

6. Final Conclusion 21

$\begin{array}{ll}\text { 7. Bibliography } & 23\end{array}$

II. Compositional Portfolio

1. Janus habet finem 27

2. Crane and Otter 35

3. Un trajet intérieur 49 



\section{Mythological Signification in Smetana's Tábor and Blaník and its Implications on Personal Compositional Output}

\section{Introduction}

From an early age, I was drawn to music as a means of expression, a storytelling mechanism that transcends limitations of language comprehension. A combination of music, and an active imagination, led me to create stories about the music I was playing, partly as a means to help with memorization, but also as a means to help with musical expression, to get absorbed into the musical realm, and just for the sheer enjoyment of creating something, seemingly out of nothing. It is only fitting then, that later on in life, I was drawn to mythological stories and their significance to the human experience, in particular, those stories that are universal and transferrable among various cultures, even though they are told through a specific language and associated with a specific cultural context. In a combination of these two interests, I decided to examine how mythology and music are interlinked, in particular, how literary narrative can be represented in instrumental music. In this exegesis, I take a close examination of two orchestral tone poems by Bedřich Smetana, Tábor and Blanik, using them as a means to discuss the concept of musical narrative, and how it may be reflected in the formal structure of a composition. The exegesis is accompanied by a portfolio of compositions that utilize mythology as their inspirational foundation, drawing lessons from Smetana's compositions. These two works were chosen because they are not tied to any dramatic, literary or operatic portrayal. I wanted to focus specifically on literary narrative being expressed solely in instrumental pieces, avoiding pieces of music that rely on actors or singers, to express their mythological stories, and to avoid the use of language as the expressive medium. I also chose Smetana's orchestral works as a way to avoid other, perhaps better-known, examples of mythologically-inspired pieces of music from the same era, such as those by Wagner, Liszt, and Grieg. What I hope to learn from this research overall, is an understanding of how literary narrative derived from mythological stories can influence the formal structure of a composition, how musical elements can express literary narrative, and to bring an awareness of these concepts to my own compositional output. 


\section{Defining Literary Narrative and the Source Material}

In my initial plans for the analysis of Tábor and Blanik, I wanted to compare the original source material that Smetana utilized for his compositional inspiration with the compositions themselves, to find parallels between the myths and the formal structure of the compositions. In essence, I wanted to apply the literary narrative of the source material to the musical narrative. However, there are some issues that inevitably arose with such an approach. The first concern is one about literary narrative in music itself. While I will avoid wading into the larger academic debate surrounding the issues of equating literary narrative with musical narrative, I would like to clarify why I am applying literary narrative to Tábor and Blanik. To begin with, I use the definition of "literary narrative" in its most simplistic and uncomplicated form, as the plot of the literary source that the composer is using. While this may be problematic for certain pieces of music that have no source material as their inspiration or foundation, Smetana makes it abundantly clear in his programme notes and writings that he intentionally composed Tábor and Blanik to invoke the myths of the Hussite warriors as a means of appealing to a Czech nationalistic identity. What we are examining in these two compositions, are the ways in which Smetana utilizes the various musical elements such as gestures, motives, orchestration and the formal structure, to imply a narrative, without the use of a lyrical or textual component directly in these pieces (such as a vocal component). The titles of these two pieces, also provide textual cues to suggest a narrative, as their names are taken from places significantly important to Czech history and mythology. While a nonCzech might not recognize the importance of Tábor and Blaník, a Czech listener will immediately recognize and call to mind the myths and stories associated with those places. Jean-Jacques Nattiez suggests that our inherent narrative listening strategies become activated from verbal cues, whether it be a suggestive or significant title, to programme notes. As he discusses in his article Can One Speak of Narrativity in Music?:

"...[N] arrative is not just written into the letter of the story. The text is still a narrative in another sense: it has been imagined by the writer or the storyteller; it is reconstructed by the reader. This is precisely the point at which there may be an analogy between literary narrative and music. Titles such as L'apprenti sorcier or Von der Wiege bis zum Grabe... indicate that there is an intention on the part of the composer to follow through a sequence of events and 
to put 'existents' forward. But only when the listener decides to link the succession of sound events according to a plot does he build up the musical work as a narrative."1

In the case of Tábor and Blanik, Smetana clearly has the intention of implying a narrative, but it is up to us as listeners to make the link between these textual cues and the narrative.

The other concern I wish to discuss, is the question regarding the source material itself. What was the source that Smetana was using as his compositional inspiration for Tábor and Blanik? We know he intended to invoke the Hussite myths, but was there a specific version of the myths (such as a romanticized version, or a poetic retelling of the Hussite myths), that he was using as inspiration? Unfortunately, it is unclear which source Smetana consulted for these pieces. The two most likely sources are the Manuscript of the Queen's Court and the History of the Czech Nation in Bohemia and Moravia by František Palacký. The Manuscript of the Queen's Court is a collection of ancient Bohemian poems and songs, "discovered" in the early 1800 s, although it was later determined to be fraudulent around the time Smetana began writing Tábor and Blaník (late 1878 and early 1879). This leaves it an unlikely candidate for a source. The writings of Palacký are more likely to be the source, as it is a highly detailed account of the history of the Czech nation, including accounts of the Hussite Wars which were first written by Palacký in 1836. The main concern I have for considering this the definitive source, is that, perhaps, it attempts to be too historically accurate, which would exclude any of the mythologized elements of the story. While it is certainly a thorough account of Czech history, I am unable to judge its historical accuracy. The other concern I have with Palackýs writing, is that he took inspiration from an earlier writer, Josef Dobrovský, who wrote a history of the Czech nation in 1792. It could also be possible that Palacký's version of the Hussite Wars is shaped by Dobrovský's accounts of the Hussite Wars, which, again, makes me wonder about the historical accuracy, given that Dobrovský was also one of the first writers to consider the Hussite Wars as something positive, as opposed to the long-held belief that the Wars were something heretical. There is however, one more aspect to consider. The writings of Palacký and Dobrovský might not be the only source materials Smetana drew upon for inspiration, if they were the source materials to begin with. While it is quite possible Smetana was familiar with the writings of

\footnotetext{
${ }^{1}$ Jean-Jacques Nattiez, “Can One Speak of Narrativity in Music?” Journal of the Royal Musical Association, Vol. 115, No. 2 (1990), 242.
} 
Palacký, there is also the possibility that accounts of the Hussite Wars have been passed down orally from generation to generation. It could be possible that Smetana knew of these myths, just from oral accounts, as opposed to any of the written accounts. Certainly, given the importance placed on these myths by the Czech people, it is quite possible that Smetana learned of these myths either in his youth, or over the course of his lifetime.

\section{Representation of Literary Narrative in 19th Century Compositions}

As Eero Tarasti mentions in Myth and Music, for 19th century composers of musical works inspired by mythology, there is a kind of dichotomy between the compositional approaches of two great composers: Richard Wagner and Franz Liszt. He maintains that “... Liszt's symphonic poem and Wagner's Gesamtkunstwerk [are] two important 'models' by which to gauge the interrelationship of myth and music in romantic culture."2 While the two composers both used mythological subject matter as their inspirational material, their approaches for portraying the literary narrative were somewhat different. Wagner favoured an approach that utilized leitmotifs, recurring themes in the music that represent various characters, ideas and locations. These motifs become associated with individual elements of the story, and the musical elements of these motifs can then be manipulated to represent changes of state for their associated narrative element. The literary narrative is portrayed through the manipulation of these motifs. In essence, ideas about the literary narrative are portrayed at the micro-level. The approach favoured by Liszt however, was to portray ideas of the literary narrative on a more macroscopic level. The literary narrative would be represented by the overarching moods and dynamics of the musical composition. Instead of emphasizing the minute details of the literary source, changes in the literary narrative would bring changes to an entire section of the composition, and subtle transformations of the thematic material are more indicative of the formal structure of a composition, as opposed to being manipulated for the sake of the narrative. In Tábor and Blanik, what we see is a preference for the latter approach, and we can clearly see the larger sectional divisions indicative of the literary narrative, while the thematic material remains largely unaltered and is a function of the formal structure, not the literary narrative.

\footnotetext{
${ }^{2}$ Eero Tarasti, Myth and Music, The Hague: Mouton Publishers, 1979, 131.
} 


\section{Approach to the Analysis}

To approach the analysis of compositions that are linked to a literary narrative, it is important to first look at what the composer's intention was for that piece of music. While some compositions will seem to be indicative of a literary narrative, and one might be able to apply a narrative to the piece, it is only the composer that knows for certain whether or not they were attempting to invoke a particular narrative. In the case of Tábor and Blanik, and the whole of Má vlast for that matter, Smetana makes it clear through his programme notes and, to some extent, the titles, which pieces invoke mythological stories ( ̌́arka, Tábor, Blaník), and which pieces reflect on the natural landscapes of his homeland (Vyšehrad, Vltava, Z českých luhư a hájů). ${ }^{3}$ While we know through his programme notes that Smetana was trying to invoke the mythological stories of the Hussite warriors, to determine the precise literary narrative for Tábor and Blanik, ideally we would look at the original source material and compare it to the compositions themselves. As mentioned previously however, we do not know for certain what his source material was. From further research into myths of the Hussite warriors and their place in Czech history, we do know the general outline of their story, and we can attempt to draw parallels between these stories and the two compositions by examining the various musical gestures, formal structures, and other musical elements present in Tábor and Blanik. However, this is very much where the most interpretation and speculation occurs.

In the writings of J. Peter Burkholder related to associative musical meaning, he discusses the concept of an "Associative Model", where "...the listener's sense of what the music means is created through a process of five steps:

\section{Recognizing familiar elements.}

2. Recalling other music or schema that make use of those elements.

3. Perceiving the associations that follow from the primary associations.

4. Noticing what is new and how familiar elements are changed.

5. Interpreting what all this means." 4

\footnotetext{
${ }^{3}$ Vyšehrad is a bit of an exception to this assertion. While the movement is largely meant to be a reflection on Vyšehrad castle, other scholars have suggested that Smetana does try to invoke the memory of the mythological bard Lubomír in this movement, represented by the harp motives, a common trope in $19^{\text {th }}$ century music to suggest a mythological character.

${ }^{4}$ J. Peter Burkholder, “A Simple Model for Associative Musical Meaning”, Approaches to Meaning in Music, Eds. Byron Almén and Edward Pearsall, Bloomington, IN: Indiana University Press, 2008, 79.
} 
This is to say, that while I am analysing Tábor and Blanik with the information I have about its construction and narrative, it is still my own interpretation of the musical material. Given the fact that I am someone who grew up in the Western musical tradition, familiar with certain elements and tropes present in the tradition, my recognition, perception, and interpretation of familiar musical elements may be different than someone who is first approaching Tábor and Blanik, who is only familiar with a different tradition. A certain musical element may convey a specific meaning in the Western musical tradition, but mean something completely different in a non-Western musical tradition. Admittedly, I am not an individual of Czech ethnicity, and am not familiar with all of the mythology and musical traditions specific to that nation first-hand. Any interpretation I give regarding the analysis of Tábor and Blanik, is specific to my associations with the musical elements and the way they are presented. To further our understanding of a piece of music, we could potentially expand the discussion and refer to the composer's other works to determine if there are any parallels between different pieces, reused gestures or musical elements that they favour to express certain narrative ideas, or even looking at other composers from whom the composer drew inspiration or ideas, however, at this point in time, I have only focussed on Tábor and Blanik, and have not compared them to his other symphonic works.

\subsection{Analysis of Tábor}

Tábor is based upon, and inspired by, accounts of the Hussite Wars of the early $15^{\text {th }}$ century, in which followers of Jan Hus ${ }^{5}$ took up arms against the armies of various Catholic nations who sought to stop the spread of the supposed heresy preached by Hus. In his programme notes for Tábor, Smetana briefly discusses the structure and inspiration behind the piece as being taken from the well-known Hussite chorale, Kdož jsú Boži bojovníci (Ye who are the warriors of God):

\footnotetext{
${ }^{5}$ Jan Hus was a priest who advocated for some reforms of the Catholic Church, and, after his death, his followers took up the cause of these reforms, igniting the Hussite Wars. The simplified version of events states that the radical Hussite followers were defeated by the Catholic nations and moderate followers of Hus. The ramifications of this loss, meant that the Czech people were then ruled by foreign powers, subjects to a monarchy and a faith that was not their own. Josef Dobrovský is perhaps the first writer who began to change the view that, instead of considering the Hussite warriors heretics, they were seen as fighters for a free Czech nation, free of subjugation to foreign powers and interests. This nationalistic perspective became increasingly popular in $19^{\text {th }}$-century Czech lands, with similar nationalistic movements occurring across various European nations.
} 
"The whole structure of the composition comes from this majestic song. In the main stronghold, in Tábor, this song surely rang out most mightily and most often. The work tells of strong will, victorious fights, constancy and endurance and stubborn refusal to yield, a note on which the composition ends. The contents of the work cannot be analysed in detail for it embraces the Hussite pride and glory and the unbreakable nature of the Hussites." 6

While it is apparent that Smetana had some sort of narrative idea behind Tábor, unfortunately his programme notes do not go into further detail on the matter. The last line is rather ironic given the circumstances, but how do these ideals and concepts espoused by Smetana manifest themselves in the music? How does he utilize the chorale in his composition, and what are its implications for the mythological narrative?

The chorale that Smetana is utilizing (Kdož jsú Boži bojovníci) originally dates back to the early $15^{\text {th }}$ century (to 1420 specifically, according to the Déjiny české hudby v prikladech, or History of Czech Music Examples) $)^{7}$, and in accounts of the Hussite wars, it was reported to have been sung by the Hussite warriors themselves before going into battle, with such tenacity and fearlessness that it struck fear into the hearts of those who heard them approaching. Just as the tales of the Hussite warriors became mythologized and embellished over the centuries, so too did Kdož jsú Boži bojovníci. The version of the chorale that Smetana utilizes for Tábor and Blanik is not the original 1420 version, but rather a version that comes from over a century later, in $1530 .{ }^{8}$ Whether this was intentional or not is unclear. Certainly Smetana's letters and correspondences do not indicate anything definitive about this particular choice, although it is quite possible that this later version was more common during the time when Smetana composed these two pieces (1878-9), and would probably have been more familiar to his audience.
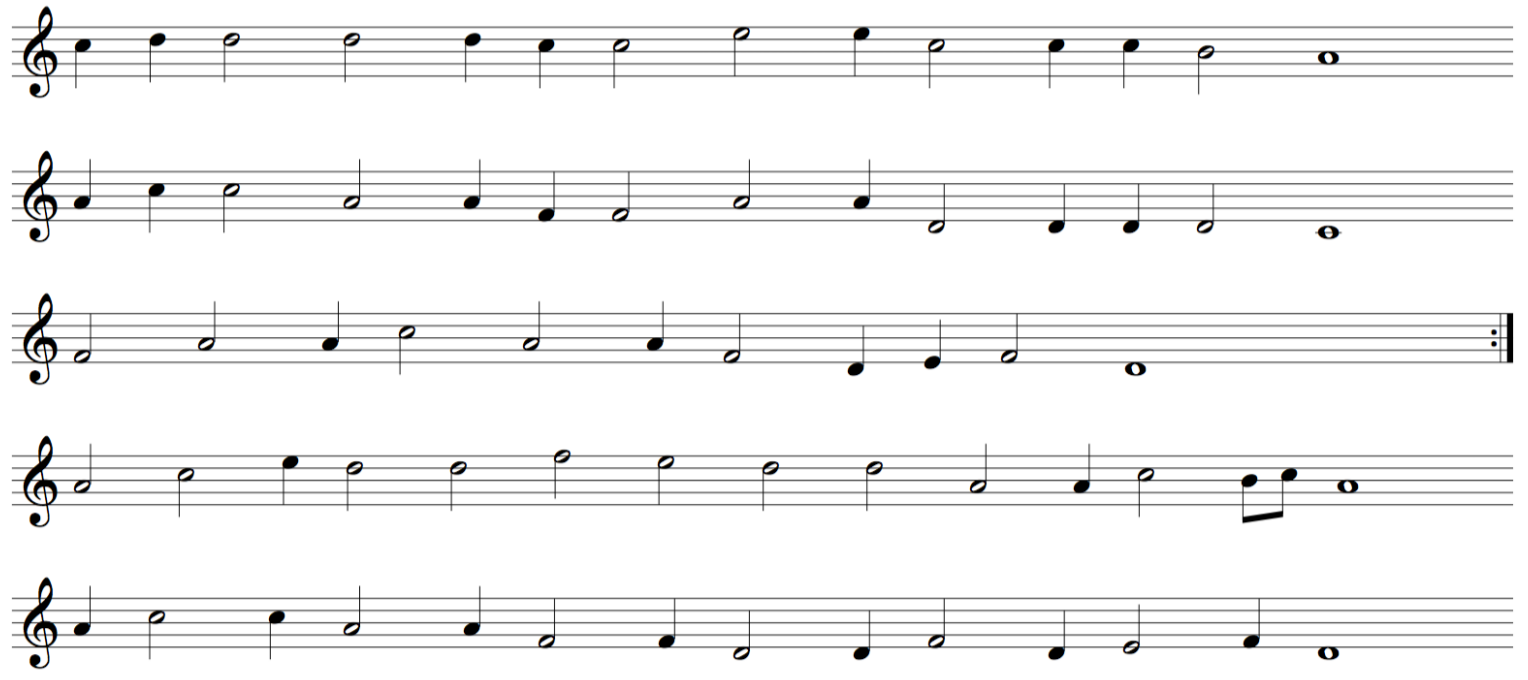

Fig. 1: Original 1420 version of Kdož jsú Boži bojovníci 


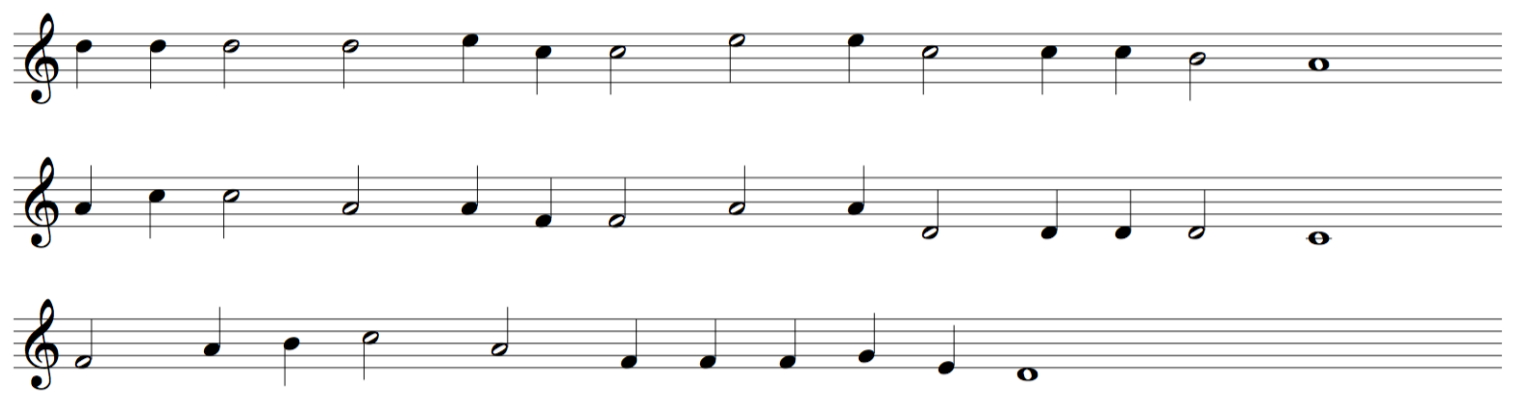

Fig. 2: 1530 version of Kdož jsú Boži bojovnici

In his programme notes for Tábor, Smetana discusses utilizing Kdož jsú Boži bojovnici as the foundation for the entire formal structure. What we might expect is an elongated and embellished version of the chorale, however, this is simply not the case. In their respective analyses of Tábor, Brian Large and David Mead disagree with the exact overall design. Large suggests that the formal construction, is a kind of musical palindrome, in which the musical material in the second half of the piece is a reflection of the musical material in the first half. ${ }^{9}$

1st Line; 2nd Line; Chorale Complete; 3rd Line //

3rd Line; 2nd Line; Chorale Complete; 1st Line

As Mead points out however, in the second half of Tábor there is a significant portion of material derived from the third line, in between the second line and the complete chorale, which “... significantly disturbs the arch form implicit in a musical palindrome...." ${ }^{10}$. Mead suggests that the first half of Tábor is closest to bar form, a formal structure with the pattern A-A-B, where the ' $\mathrm{B}$ ' section is slightly longer than the the two preceding sections combined. He is quick to point out however, that it does not follow bar form in a strict sense, as the second 'A' section is not an exact repetition, and the ' $\mathrm{B}$ ' section is roughly in equal length to a singular ' $A$ ' section. The second half of Tábor is ".... a nearly seamless flow running to not quite 300 measures (in a generally very fast tempo) and over six minutes' playing time... The form has points of structural articulation, but these only slightly change the course of the flow without interrupting it."11.

\footnotetext{
${ }^{9}$ Brian Large, Smetana, New York: Praeger Publishers, 1970, 283.

${ }^{10}$ David Mead, “The Symphonic Structure of Smetana's 'Má vlast”, diss., University of Texas at Austin, 1994, 127.

${ }^{11}$ Mead, 134.
} 
What I would like to propose, at least for the purposes of linking the literary narrative to the compositional structure, is a simplified formal design. An introductory section, followed by a statement of the entire chorale, is then followed by a substantial transitional section that takes the piece to a restatement of the chorale, and a conclusion section.

Introduction - Chorale - Transition - Chorale - Conclusion

In the introductory section of Tábor, what we see is, in essence, a calling; an invocation for the warriors to appear. This invocation has a secondary meaning however. It is not just an invocation for the warriors to appear, but also an invocation for the Czech people to unite, to answer the call to arms and fight off foreign rule. The quiet and sparsely orchestrated opening, with horns, low strings and bassoons, creates a sense that this calling is coming from a distance. In the first 23 bars of Tábor, we are hearing a constant repetition of a repeated ' $d$ ' motive, emphasizing on the first four notes of the chorale. This correlates to an emphasis on the first three words of the chorale: Kdož jsú Boží. The full first line, Kdož jsú Boži bojovníci, translates into You who are God's warriors, or alternatively, You, who are the warriors of God. With the exclusion of the word bojovnici, this has the effect of changing the meaning to something more akin to You who are of God, or You who belong to God. This could be seen as being a way to be inclusive to all of God's people (in this context, all of the Czech people), but the repeated ' $d$ ' pattern is also reinforcing the idea that Smetana wants Czech listeners to recall this particular chorale. The underlying harmonic accompaniment is simply chromatic motion creating tension and a sense of momentum that is not provided by the repeated ' $d$ ' pattern. After these initial 23 bars, we finally have the resolution of the initial chorale line in bb. 24 and 25 . There are a number of repetitions of this resolution, and the number of repetitions corresponds to the number of repetitions of the first half of the line. While providing balance to the opening, this could also be interpreted as a subtle indication that all of the calls that were put forth were answered. These opening 31 bars are repeated, albeit transposed onto the minor dominant, with a slight alteration at the end of the second iteration, an inclusion of the second half of the chorale's opening line (bb. 59-61).

Bar 63 introduces the second line of the chorale, with a choral passage in $\mathrm{C}$ major, which seems a bit out of place, given the militaristic and bombastic opening in the key of D minor. However, this chorale is meant to provide a moment of peacefulness and tranquility. 
The second line of Kdož jsú Boží bojovníci, which is the basis for this choral passage, reads Prostež od Boha pomoci a úfajte v něho, or, Pray to God and have faith in Him. Narratively, it functions as a moment of rest and contemplation, a prayer to God before marching into battle, which is represented in the next transitional passage as scalar passages and fragmentary material of the first line, with some trumpet calls in the background. This transitional passage moves the piece into A major, the dominant key of the original D minor, but instead of resolving back to the original key, Smetana introduces the full Hussite chorale in its enharmonic equivalent of D major. The entire material up to this point is introductory in nature. Its overall function is to set up the introduction of the full chorale. The fragmentary nature of the material suggests that there is no clear melodic or motivic material being developed and manipulated that would suggest otherwise. It hints at it, but never comes to fruition. However, it all still has a narrative function.

The first full statement of the chorale begins in a triumphant fashion in D major. This is representative of the zeal and defiance of the Hussite warriors (the "pride and glory" that Smetana refers to in his programme notes) as they sing this chorale before going into battle. In both the introductory iteration and this triumphant version of the chorale, the second line of the chorale, the prayer to God, is given the same instrumentation (clarinets and bassoons, with a slight use of oboe) and is built on the same harmonies. They are carbon copies of each other. While this is entirely intentional, is there a narrative implication, or is this merely the version that the audience would be most familiar with? While the introductory section put forth the fragmented pieces of the first and second lines of the chorale, it is not until bar 98 where we are finally given the third and final line of the chorale. ${ }^{12}$

Following this Grandioso section, there is a rather substantial and lively transitional section, initially derived from the final half of the third line of the chorale.

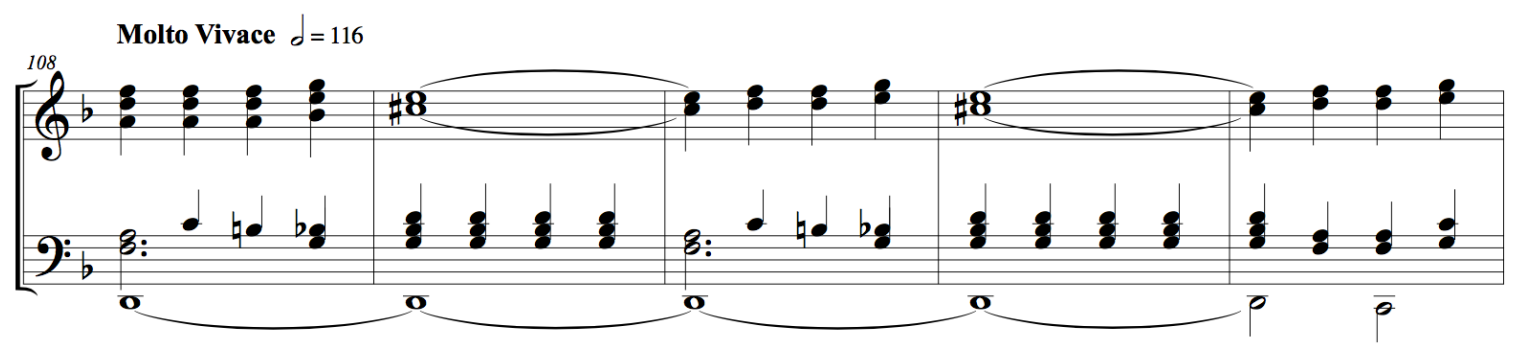

Fig. 3a: Reduction of transitional material in Tábor

12 Third and final line in the version of the chorale that Smetana uses as the compositional foundation. The earlier version from the $15^{\text {th }}$-century, aside from a few notational differences, is structured slightly differently. In this earlier version, the first few lines are repeated, and followed by a chorus. 


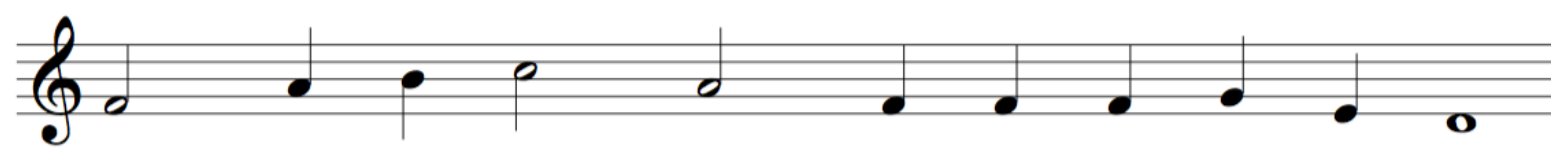

Fig. 3b: Third line of the chorale

This is largely unimpeded (except for a brief return of the choral passage, transposed, in bb. 134-7), until bar 184, where this transitional material shifts to a constant repetition of A major chords, a transposition of the initial ' $d$ ' pattern to the major dominant of the opening key. However, instead of resolving to any sort of recapitulation in the opening key, it moves to the enharmonic minor (A minor), followed by movement through numerous keys and their respective enharmonic minor pairings. There is a constant back-and-forth from major to minor, a reference to the battle between the heroic Hussite warriors and their enemies, until, finally, in bar 264, there is a clear indication that it has moved to the major key, making its way to D major, which is then followed by a series of major chords leading into bar 290. This tonally major passage, particularly from bb. 268-89, is also less active rhythmically, than a significant portion of the preceding material. However, this is short-lived.

While the battle continues to rage on, there is a return of the full statement of the Hussite chorale, a rallying cry of sorts, to try and keep the warriors from being defeated, to mount one last stand against their foes. The opening line of this second iteration of the full chorale, ends on an A minor chord, as opposed to the earlier iteration which ends the opening line on an A major chord. This subtle change of harmony, is perhaps, the strongest indication that the battle is not going in favour of the warriors. That, and the underlying rhythmic activity of this second iteration, which is increased from the first iteration, creates a sense of unease and urgency. Even the second line of the chorale, which had previously held steady even in the midst of the battle (bb. 134-7; transposed down a step from the version of the second line in the full statement of the chorale), has this sense of urgency. The instrumentation has the melodic line played by the flutes, oboes, and a single horn, which is scarcely heard above the clarinets, bassoons, and horns simultaneously playing a countermelody, while the strings are hurriedly playing the harmonic sonority. The iteration of the third line of the chorale brings some stability to the passage, with the winds and brass playing the same rhythmic melody, while the strings continue the frantic harmonic underpinning. 
The final section, the conclusion of Tábor, is not really a coda in the traditional sense. The last stand of the Hussite warriors is depicted in the constant refrain of the trumpets and strings, the latter of which is in a rhythmically diminutive form from the opening repeated ' $d$ ' motive.

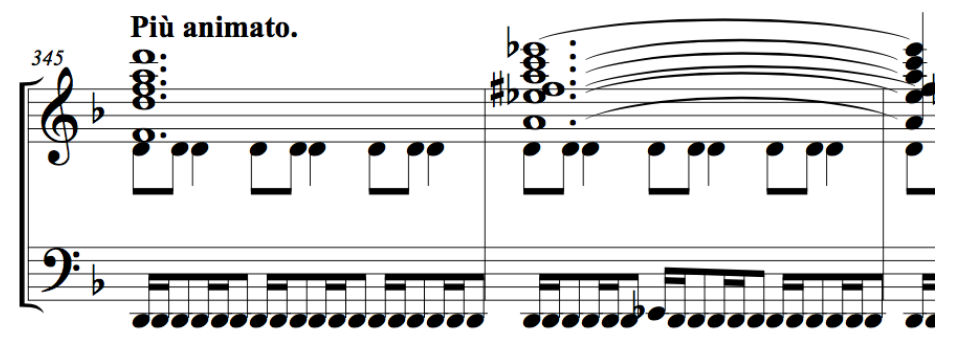

Fig. 4: Reduction of material from the final section of Tábor

The much slower chordal harmonies in the horns and woodwinds create a sense of dread and foreboding. While most codas end with a prolonged pedal on the tonic, Smetana purposely begins this conclusion with the prolonged pedal. The harmonic movement, beginning in bar 369 , is a purposeful continuation of the piece, which, when coupled with the repeated motive in the horns and brass (fragmentary material of the first line of the chorale), is indicative of the warriors continuing on, or at the very least, their spirits continuing on. It is not until bar 399 , that we have a proper tonic pedal to close the movement. However, due to the relatively short amount of time, and the lack of a proper dominant-to-tonic cadence, the piece does not come to a satisfactory conclusion, at least, not when it is played on its own. Instead, these final ten measures, are meant to act as a continuation into Blanik.

\subsection{Analysis of Blanik}

While Tábor is fairly straightforward and uncomplicated to analyse and interpret, the movement of Blaník is a bit more complicated. As the final tone poem in Má Vlast, Smetana not only ties in pre-existing material from Blanik's companion Tábor, he also uses material from the earlier pieces of Vyšehrad and Vltava, to bring the suite to a tight conclusion. There are a number of myths surrounding Blaník (a mountain that has played an important and central role in Czech history), but perhaps the most well-known myth is the myth of the warriors of St. Wenceslas who slumber in the mountain, to rise up when the Czech lands are in great peril, fighting for the freedom of the Czech people. Interestingly, Smetana links this myth with the myth of the Hussite warriors, as described in his programme notes: 
"This is a continuation of the preceding composition Tábor. After their defeat the Hussite heroes hide in Blanik hill and wait, in profound sleep, for the moment when they are to come to the help of their country." 13

While this connection between the two myths is intentional, it is unclear whether Smetana was the first to link the two myths, whether the two were linked by writers who were contemporaries of Smetana, or whether the two were linked much earlier. In any case, Blanik is similar to Tábor, in that they both share the chorale Kdož jsú Boží bojovníci as their structural foundation, and narratively, in that the narrative of Blanik is a continuation of the events after Tábor.

"The same motives as in Tábor also serve Blanik as the foundation for the structure, i. e. 'Ye who are Warriors of God!' On the basis of this melody (the Hussite motif) the resurrection of the Czech nation, its future happiness and glory develops; with the victorious hymn in the form of a march, the composition and thus the whole cycle of the symphonic poems ' $M y$ Country' is concluded." 14

The introductory 14 bars of Blanik feature the same opening motif as Tábor, derived from the first line of the chorale Kdož jsú Boži bojovníci. Smetana uses this unambiguous reference to inform the audience that we are still invoking the Hussite legends. It is the aftermath of the battle that took place in Tábor. Harmonically, this introduction prepares us for the tonic key of the first theme (via a diminished seventh chord), which is also the tonic key of the previous tone poem. The theme that begins in bar 15 should likely be considered a variation or, at the very least, a derivation of the first line of the chorale, as they bear some striking resemblances to each other. While the overall theme is very much like a march, this is not the same triumphant march that we heard in Tábor before the battle, given the orchestration which is largely just the string section, punctuated with woodwind figurations. Rather, this is the march of a defeated force, on their way to their resting place in the mountain. While a few exclamations of the original motive occur, such as in bar 50 in the woodwind section, they are very much alone in their sentiments. They are the rebels who still

\footnotetext{
${ }^{13}$ František Bartoš, Bedřich Smetana: Letters and Reminiscences, trans. Daphne Rusbridge (Prague: Artia, 1955), 265.

${ }^{14}$ Bartoš, 265.
} 
exclaim their defiance. Eventually the warriors reach their destination, where they will sleep until called upon, as the theme becomes softer, and elongated in the final measures of this first section (bars 61-69).

The next section of Blanik is the "small intermezzo" that Smetana describes in his last sentence of programme notes on the movement:

"As a small intermezzo there is also a short idyll contained in this work, a sketch of the landscape around Blaník, a little shepherd-boy rejoices and plays (oboe) and the echo answers him."15

There is a brief transition between the previous section and this new section. The oboe melody that is initially presented (bb. 70-80) is misleading, or, rather, the first half of the melodic material presented is misleading, as it only serves a transitional function to move towards the true melodic material in bb. 78-80. This "true" melody, derived from the second line of the chorale, becomes the foundation for the new section (bb. 84-138), canonically imitated by the horn, and later, clarinet, an octave below the oboe. These are the echoes that answer the shepherd-boy. In his harmonic analysis of Má vlast, Mead asserts that the movement of the bass line, to a prolonged $\mathrm{F}$ makes this section imitative of the bagpipes, citing Michael Beckerman's discussion on recurring symbols to portray the folk ethos. I am not entirely convinced that this passage is indeed imitating a bagpiper, due to the delicate and flowing nature of the melodic material.

The transitional material between the second and third sections (bars 139-164), seems to be a variation on the second line of the chorale, although more rhythmically active, very different harmonically, and a different function narratively. This is the transition between the beautiful, serene pastoral scene, and the introduction of something much worse.

The third section, appears to be thematically unrelated to any previous motifs or themes presented in either Tábor or Blanik. In some ways it seems like a large transitional section: the inconsistent phrase lengths, the incessant triplet quaver rhythm, and the harmonies which move through a downward circle of fifths all combining to create a feeling of uneasiness. Narratively, however, we can surmise that this passage is analogous to the trouble and turmoil that befell the Czech nation after the defeat of the Hussite warriors, the

\footnotetext{
${ }^{15}$ Bartoš, 265.
} 
centuries of rulers from a distant throne. Although it seems as if this thematic material is unrelated, I would like to posit that it is actually derived from a variation of the second line of the Hussite chorale. The contour of the passage is very similar to the second line of the chorale, if it were written out in reverse. The rising second, followed by the rising fourth in this passage, recalls the falling fifth and falling second at the end of the second line. The movement by thirds in the chorale has a similar contour to the movement found in the passage. From the earlier discussion regarding Tábor, we know the symbolic nature of this passage as being a prayer to God, and up until this point, has been treated rather carefully, without much variation. Perhaps Smetana is implying that the foreign rulers are equal to this bastardized version of the prayer to God, that is to say, they are unholy or unfit to govern the Czech people. Perhaps this is too much conjecture on my part, but it seems odd to me that while the themes and motifs found in Tábor and Blanik are all largely derived from Kdož jsú Boži bojovnici, that this would be the one major theme that is unrelated. Potentially, it could also be derived from the opening of the third line, a rising line that has the outline of a rising fourth to a rising second (if we disregard the second note of the phrase), the inverse of the rising second to a rising fourth.

The fourth section, is perhaps the most important part of both Tábor and Blanik. It is the climax of the two pieces, and perhaps, of the entire Má Vlast suite. Thematically, the material is derived from the third line of the Hussite chorale. In the same way that Blanik can be considered to be in four sections, so too can this particular section. The first three statements of this march theme are continually interrupted by transitional material in the penultimate phrase until finally, in the fourth iteration, the march is able to be heard in its complete form, with its final note signalling the start of the coda. This is the symbolic representation of the resurrection of not only the Hussite warriors, but the Czech nation. The thematic material begins softly, with a solo horn above staccato strings, before moving to the clarinets above pizzicato strings and staccato bassoon. After the interruption of this initial presentation of the theme, the second iteration becomes stronger, orchestrated with the entire woodwind section, while still retaining its delicate quality. Eventually, the third iteration (bar 287 ) is the explosive triumph of the climax, with the full orchestra playing the thematic material. This climactic moment represents the emergence of a strong, proud, and independent Czech nation. The interrupting material after the climax is largely derived from 
the same material as the march theme. While parts of it seem harmonically unsettled, when the theme returns for the fourth iteration in bar 362, it is clear that any problems that were there, have been resolved.

The coda, beginning in bar 389 , is a summation of the entire cycle, and is excellently described by Mead:

"Smetana seeks to bring together in a single moment Bohemia's past and future... The past is represented by the two primary motives from Vyšehrad, the present and future by the Hussite chorale. ... This moving and bracing conclusion conjures an image... of the Czech people, having seen this vision of a blessed future, rushing to meet it, perhaps even at a run. The music ends as they disappear from sight." 16

What I hope is clear from my analysis is that both pieces are structured the way they are as a function of the literary narrative. Blanik is divided into four sections (with a short introduction and coda), each with their own narrative function, while Tábor is divided into a quasi-binary form with a substantial transitional section in the middle, bookended with an introduction and coda.

\subsection{Conclusions to Draw from Tábor and Blaník}

What I hope this analysis shows, is that both Tábor and Blanik are structured the way they are as a function of their respective literary narratives. Tábor is divided into a quasibinary form with a substantial transitional section in the middle, bookended with an introduction and coda, which pairs well with the overall literary narrative of a battle and the events preceding and succeeding it. Blanik, representative of the aftermath of the battle featured in Tábor, with the defeated warriors retreating to the mountain, and the darkness that befalls the Czech people until the restoration of their nation, is divided into four distinct sections denoting the changing of this narrative over time. Each of these sections is fairly well-defined by the nature and quality of the motivic material present, which represents the broader ideas of the literary narrative, such as in the opening of Tábor where the repeated ' $d$ ' motive defines the introduction, the invocation for the warriors to appear, but is not used in the same manner anywhere else in the remainder of Tábor or Blaník.

\footnotetext{
${ }^{16}$ Mead, 157-8.
} 


\section{Conclusions to apply to my own compositions}

The preceding analysis of literary narrative in Tábor and Blanik has provided me with ideas on how to approach portraying literary narrative in my own compositions, particularly with focussing my attention on the structure of the piece to reflect the overall mood and overarching narrative of the inspirational material. It has given me pause for thought in regards to compositional form, and potential strategies to apply to my own compositional output. The larger discussion surrounding the approaches taken by Liszt and Wagner has also been beneficial, as it suggests that there is more than one way to approach the issue which I hope to further explore in my work. The compositional portfolio that accompanies this writing, is an attempt to explore a couple of different approaches to literary narrative and all of the compositions that I have created over the course of this study, have been in an attempt, in some capacity, to create music that invokes the essence of the mythological, or mythologically inspired, sources that I consulted for inspiration. For the sake of clarity, I shall discuss the compositions individually, and explain the compositional choices I made to invoke a sense of the mythological, or how the mythology influenced my compositional design choices.

\subsection{Analysis of Janus habet finem}

Janus habet finem is based on a Latin text by Ovid, from the introduction of his second book of Fasti. One of the reasons for this was for a desire to enter the completed piece to the 13th International Competition of Choral Composition "Seghizzi" 2015, out of Gorizia, Italy, which requested that entries preferably be based on a text by Ovid, Horace, Virgil or Catullus. As such, I chose this particular passage from Ovid. Fasti, known in English as the Book of Days, is a collection of books, in which a narrative character asks the gods why they commemorate certain days of the calendar year, and what the significance of those commemorations are. The English translation for the part of the text I chose to set:

January is done, and the year advances with my song. As the second month runs, so let the second book. For the first time, my verses, sail with more canvas,

Your theme, I recall, has been slight until now.

I found you ready enough servants of love, When I toyed with poetry in my youth, 
Now I sing of sacred rites and calendar days:

Who would have thought it would come to this? ${ }^{17}$

As we can see in the text, the themes presented in this passage discuss the passing of time, aging and life not turning out the way the character envisioned it would, which is also a subtle reference to Ovid's own journey through life. All of this still has an underpinning of the central theme to the entirety of Fasti: a spiritual or religious connection. In composing Janus habet finem, I had to keep in mind that this was not just a reflection of Ovid's own life, but was also a reflection on religious rituals. To achieve this ideal, there is a recurring rhythmic and harmonic passage that serves as a kind of religious chant (or, at the very least, is what I equate as functioning like a religious chant), which is followed by a quiet, reflective passage dominated by a solo vocal line, while the other voices provide a slow harmonic underpinning. The essence of Janus habet finem is this duality between religious contemplation and one's own reflection on life.

\subsection{Analysis of Crane and Otter}

The string quartet Crane and Otter came out of an attempt to take a more literal approach to mythological narrative, a more Wagnerian approach, if you will, in which certain motifs are equated with certain characters and situations. This string quartet is based on a myth of the Assiniboine people, describing how the crane got its black and red markings and how the otter is able to live underwater during the winter. As such, I decided to try a more literal approach, subscribing a different character of the myth to each of the four instruments in the quartet: the Mother Crane, the Young Crane, the Otter, and the cold (who becomes personified by the god Osni'). There was no particular reason why I chose this myth, other than out of sheer interest and the fact that its straightforward narrative allowed me to take a different approach from Janus habet finem. Similar to the continual narrative found in Blanik, where the four unique sections represent different parts of the narrative, to create the formal structure, I sectionalized the myth into four parts that I thought represented the major plot points of the overarching literary narrative, and created the motivic material to best represent these sections. The opening section (bb. 1-37) is meant to invoke a conversation between the characters of the Mother Crane, Otter, and Young Crane, represented by the violins and viola,

\footnotetext{
${ }^{17}$ Ovid, Fasti, trans. A.S. Kline, Poetry in Translation, A.S. Kline, poetryintranslation.com, Web.
} 
in the bleakness of winter. To represent this motivically, there is an interplay between the viola motifs (Mother Crane), the echoing of these motifs in the second violin with tremolo (Young Crane), and the playfulness of the pizzicato first violin (the Otter). This interplay of the viola and first violin creates a conversation between the two instruments until the viola part fades away (bar 30) and leaves the two violins alone together. The opening cello line (representing the bleakness of the winter), and its subsequent repetition, functions as a harmonic underpinning to this opening section.

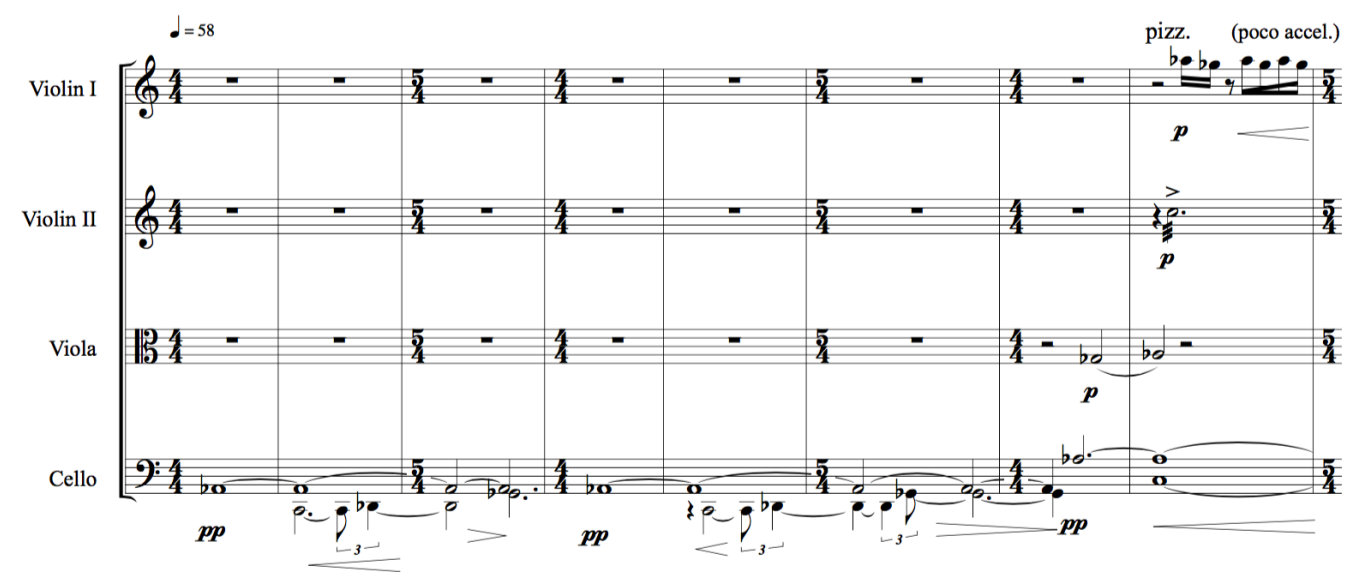

Fig. 5: Opening measures of Crane \& Otter

Beginning in bar 38, the beginning of the second section meant to represent the kidnapping of Young Crane, the cello part becomes the personification of the cold: the god Osni'. Since the character represented by the viola has momentarily left (the Mother Crane has flown south for the winter), the viola takes over the harmonic material, at least until the first climactic moment of the piece (bb. 46-9), Osni's killing of Otter, after which the cello and second violin remain. The section beginning in bar 60 , corresponds to the part of the myth where the Young Crane is left alone to attend to the fire of Osni', continually stoking it for the god. As such, I tried to represent the fire with the increased rhythmic pizzicato passages of the cello, viola, and first violin, accelerating and decelerating at slightly different points to create a randomized rhythmic passage. The fourth section (the concluding section) beginning in bar 72, is meant to signify the return of the Mother Crane character, and their subsequent visit with the other otters. Some motivic material from the opening section, representative of the various characters, is reiterated, and a quasi-chorale section brings the piece to a contemplative and harmonic close. 


\subsection{Analysis of $U$ U trajet intérieur}

Un trajet intérieur (A Journey Inward) is by far the most ambitious project I undertook over the course of this year, and is inspired by the mythological concept of the hero's journey. Joseph Campbell describes the concept thus:

"The standard path of the mythological adventure of the hero is a magnification of the formula represented in the rites of passage: separation - initiation - return: which might be named the nuclear unit of the monomyth. A hero ventures forth from the world of common

day into a region of supernatural wonder: fabulous forces are there encountered and a decisive victory is won: the hero comes back from this mysterious adventure with the power to bestow boons on his fellow man."18

While I had a particular heroic myth in mind for this piece, I prefer to keep that a secret as I do not want the listeners of this piece to think about a particular hero, but rather, I want the listeners to derive their own myth or story from the music; a kind of exercise in discovering oneself, or taking a journey inwards. Unlike Tábor and Blanik, which invoke specific myths from their titles alone, I did not want to invoke any particular myth in the minds of the listeners.

For Un trajet intérieur to represent "the rites of passage" of separation, initiation, and return, I followed a similar structural design to Tábor. Although different in terms of the narrative subject matter, Tábor follows a similar narrative formula in that there is a journey to a specific point, a transformative event that happens, and a return journey that is altered from the event that has unfolded. In Un trajet intérieur there is an introduction of 20 bars, a string chorale that provides a sense of comfort, stability and familiarity. In essence, a sense of being at home. The accelerated arpeggiated motif in the piano provides the forward momentum that signifies the beginning of the journey, but is also incredibly important to the core of the piece, similar to how the opening ' $d$ ' motive in Tábor gains significance as that piece unfolds. In the first main section of Un trajet intérieur (bb. 21-62), the arpeggiated motif becomes the core of the harmonic landscape, providing a constant rhythmic underpinning that can be adapted to provide momentum, or to provide a contemplative background, while the sustained harmonies in the strings and woodwinds move around it. The oboe and cor anglais provide a sense of a melodic line, derived from the movement of the first violins, although it is meant

\footnotetext{
18 Joseph Campbell, The Hero with a Thousand Faces, Princeton, NJ: Princeton University Press, $1968,30$.
} 
to invoke a sense of movement and direction as opposed to being a true melodic line. The climactic moment in bar 44 suggests a movement towards a harmonic area that is different than what has come previously before it, however the arpeggiation figure still remains in a transposed form, keeping the music in a similar harmonic area. A simple melody in harp, piano, and oboe, propels us towards a climactic moment that signifies the entrance into a new, distinct harmonic area.

While the preceding material has largely been based around an (01347) pitch-class set (an octatonic subset), this new harmonic area is based around its complement (25689te), or (0134569) when put in its prime form. The mythological signification then, is a movement towards an opposite. If the preceding material is considered 'light', then this new harmonic area is 'darkness'. However, it does not completely reveal itself just yet. In this new section (bb. 63-100), initially there is a sparsity to the string harmonies, with a major quality to the chord itself, while the woodwinds take turns playing a melody reminiscent of the earlier arpeggiated motif in the piano (bb. 13-20). The slowness and sparseness of this passage, gives the passage a sense of foreboding and uneasiness, while the sweetness of the woodwind melodies are meant to be representative of the idea that the darkness is beckoning one towards it through the use of sweet words (similar to the concept of the Siren's song in the Odyssey by Homer). This passage is the calm before the storm, leading to the reveal of the darkness that comes in the next section (bb. 101-119), a section defined by its chaotic and confused nature, a culmination of earlier motivic and melodic ideas presented earlier in the piece. The last section of Un trajet intérieur (bb. 120-149) is very much similar to the first main section (bb. 21-62). After a brief transitional period after the climax of bar 119, the chaos and confusion is resolved to the sustained harmonies in the strings and woodwinds, with the piano providing the stable arpeggiated harmonic underpinning as seen previously. This final section brings the journey, and the piece, home again.

\section{Final Conclusion}

As stated previously, what I wanted to learn and take away from this research, was an understanding of how literary narrative derived from mythological stories can influence the formal structure of a composition, how musical elements can express literary narrative, and to bring an awareness of these concepts to my own compositional output. While the analysis of 
Tábor and Blanik has been interesting, there is much more that I can take away from examining these two pieces further (and the whole of Smetana's repertoire), in terms of treatment of harmonic development, motivic development, and orchestration techniques. I feel that this brief discussion has only scratched the surface of some of the issues, concerns and approaches one may have with the concept of literary narrative in music, and it is something that I plan to explore further going forward. However, with all of that being said, this research has given me new ideas on how to approach compositions based on mythological and literary sources, and has helped me focus more on the structural aspects of my own compositions. It has allowed me to further examine the relationship between mythology and music, affording me the opportunity to take an in-depth look at some of my personal interests, and given me ideas and concepts to explore further in the future. 


\section{Bibliography}

Abbate, Carolyn. Unsung Voices: Opera and Musical Narrative in the Nineteenth Century. Princeton, NJ: Princeton University Press, 1996.

Agawu, Kofi. Music as Discourse: Semiotic Adventures in Romantic Music. New York: Oxford University Press, 2009.

Almén, Byron. A Theory of Musical Narrative. Bloomington, IN: Indiana University Press, 2008.

Almén, Byron, and Edward Pearsall, eds. Approaches to Meaning in Music. Bloomington, IN: Indiana University Press, 2006.

Bartoš, František. Bedřich Smetana: Letters and Reminiscences. Trans. Daphne Rusbridge. Prague: Artia, 1955.

Beckerman, Michael. "In Search of Czechness in Music." 19th-Century Music, Vol. 10, No. 1 (Summer, 1986), pp. 61-73. JSTOR. Web. October 25, 2015.

Bruhn, Siglind, ed. Sonic Transformations of Literary Texts: From Program Music to Musical Ekphrasis. Hillsdale, NY: Pendragon Press, 2008.

Campbell, Joseph. The Hero With A Thousand Faces. 2nd ed. Princeton, NJ: Princeton University Press, 1949.

Collman, Peter. "Episode 13: The Life and Death of Jan Hus" Bohemican podcast. July 15, 2013.

Cosper, David. “Interpretation, Narrativity, and Musical Performance.” Diss. University of Virginia, 2011. ProQuest Digital Dissertations Web. April 5, 2015.

Hopkins, Pandora. "The Homology of Music and Myth: Views of Lévi-Strauss on Musical Structure.” Ethnomusicology, Vol. 21, No. 2 (May, 1977), pp. 247-261. JSTOR. Web. Aug. 9, 2015.

Koldau, Linda. "Monotonie und Dynamik. Smetanas Symphonische Dichtung 'Tábor'." Die Musikforschung, Vol. 59, No. 4 (October-December 2006), pp. 328-345. JSTOR. Web. May 24, 2015.

Kopeček, Michael, and Balázs Trencsényi, eds. Discourses of Collective Identity in Central and Southeast Europe (1770-1945). New York: Central European University Press, 2006.

Krueger, Rita. Czech, German, and Noble: Status and National Identity in Habsburg Bohemia. Oxford: Oxford University Press, 2009. 
Large, Brian. Smetana. New York: Praeger Publishers, 1970.

Leerssen, Joep. "Romanticism, music, nationalism." Journal of the Association for the Study of Ethnicity and Nationalism, Vol. 20, No. 4 (2014), pp. 606-627. JSTOR. Web. March 16, 2015.

Lévi-Strauss, Claude. Myth and Meaning. London: Routledge, 2014.

Malý, Miloslav. Bedřich Smetana. Prague: Orbis, 1976.

Maus, Fred. "Narrative, Drama, and Emotion in Instrumental Music." The Journal of Aesthetics and Art Criticism, Vol. 55, No. 3 (Summer, 1997), pp. 293-303. JSTOR. Web. March 31, 2015.

Mead, David. “The symphonic structure of Smetana's 'Má vlast."” Diss. University of Texas at Austin, 1994. ProQuest Digital Dissertations Web. Sept. 11, 2015.

Monelle, Raymond. The Sense of Music: Semiotic Essays. Princeton, NJ: Princeton University Press, 2000.

Murgatroyd, Paul. Mythical and Legendary Narrative in Ovid's Fasti. Ledien: Koninklijke Brill NV, 2005.

Nattiez, Jean-Jacques. "Can One Speak of Narrativity in Music?” Journal of the Royal Musical Association, Vol. 115, No. 2 (1990), pp. 240-257. JSTOR. Web. June 14, 2015.

Ovid. Fasti. Trans. A.S. Kline. Poetry in Translation. A.S. Kline, April 10, 2004. Web. March 15, 2015. < http://www.poetryintranslation.com/PITBR/Latin/Fastihome.htm $>$.

Ovid. Fasti. Trans. James George Frazer. Cambridge, MA: Harvard University Press, 1967.

Palacký, František. Dějiny národu českého w čechách a w morawě dle pưwodních prameni̊w wyprawuje: Dílu III Částka I. Od roku 1403 do 1420. Praha: Nákladem Knihkupce F. Tempského, 1877. Google Books. Web. May 17, 2015.

Pohanka, Jaroslav. Dějiny české hudby v přikladech. Praha: Státní nakladatelství, 1958.

Smetana, Bedřich. Má vlast. Ed. František Bartoš. Prague: Bärenreiter, 2013.

St. Pierre, Kelly. "Re: Smetana and Mythology.” Message to the author. March 22, 2015. E-mail.

St. Pierre, Kelly. "Smetana's 'Vyšehrad' and Mythologies of Czechness in Scholarship." 19th-Century Music, Vol. 37, No. 2 (Fall 2013), pp. 91-112. JSTOR. Web. 
March 16, 2015.

Supičić, Ivo. "Music and Ceremony. Another Aspect." International Review of the Aesthetics and Sociology of Music, Vol. 13, No. 1 (June 1982), pp. 21-38. JSTOR. Web. June 16, 2015.

Tarasti, Eero. Myth and Music: A Semiotic Approach to the Aesthetics of Myth in Music, especially that of Wagner, Sibelius, and Stravinsky. The Hague: Mouton Publishers, 1979.

Tarasti, Eero. Signs of Music: A Guide to Musical Semiotics. New York: Mouton de Gruyter, 2002.

Tarasti, Eero. A Theory of Musical Semiotics. Bloomington, IN: Indiana University Press, 1994.

Tarasti, Eero. "Über mythische aspekte im Schaffen Smetanas.” Bedřich Smetana 1824-1884, Congress Report. Prague, 1994. Eds. Olga Mojžíšová and Marta Ottlova. Prague, 1995.

Taruskin, Richard. "A Myth of the Twentieth Century: The Rite of Spring, the Tradition of the New, and 'The Music Itself.'" Modernism/Modernity, Vol. 2, No. 1 (1995), pp. 1-26. John Hopkins University Press. Web. June 16, 2015.

Wratislaw, A.H., trans. Manuscript of the Queen's Court: A Collection of Old Bohemian Lyrico-Epic Songs with Other Ancient Bohemian Poems. Prague: Venceslav Hanka, 1852. Google Book Search. E-Book. March 23, 2015. 



\section{JANUS HABET FINEM (2015)}

JAMES A. SKIERKA

CHORAL WORK FOR

S-A-T-B 



\section{Janus habet finem}

Janus habet finem: cum carmine crescit et annus;

Alter ut hic mensis, sic liber alter eat.

Nunc primum velis, elegi, majoribus itis:

Exiguum, memini, nuper eratis opus.

Certe ego vos habui faciles in amore ministros,

Cum lusit numeris prima juventa suis.

Idem sacra cano, signataque tempora fastis.

Ecquis ad hæc illinc crederet esse viam? 



\section{Janus habet finem}

$$
d=60
$$

Composer: James A. Skierka Lyrics: Ovid
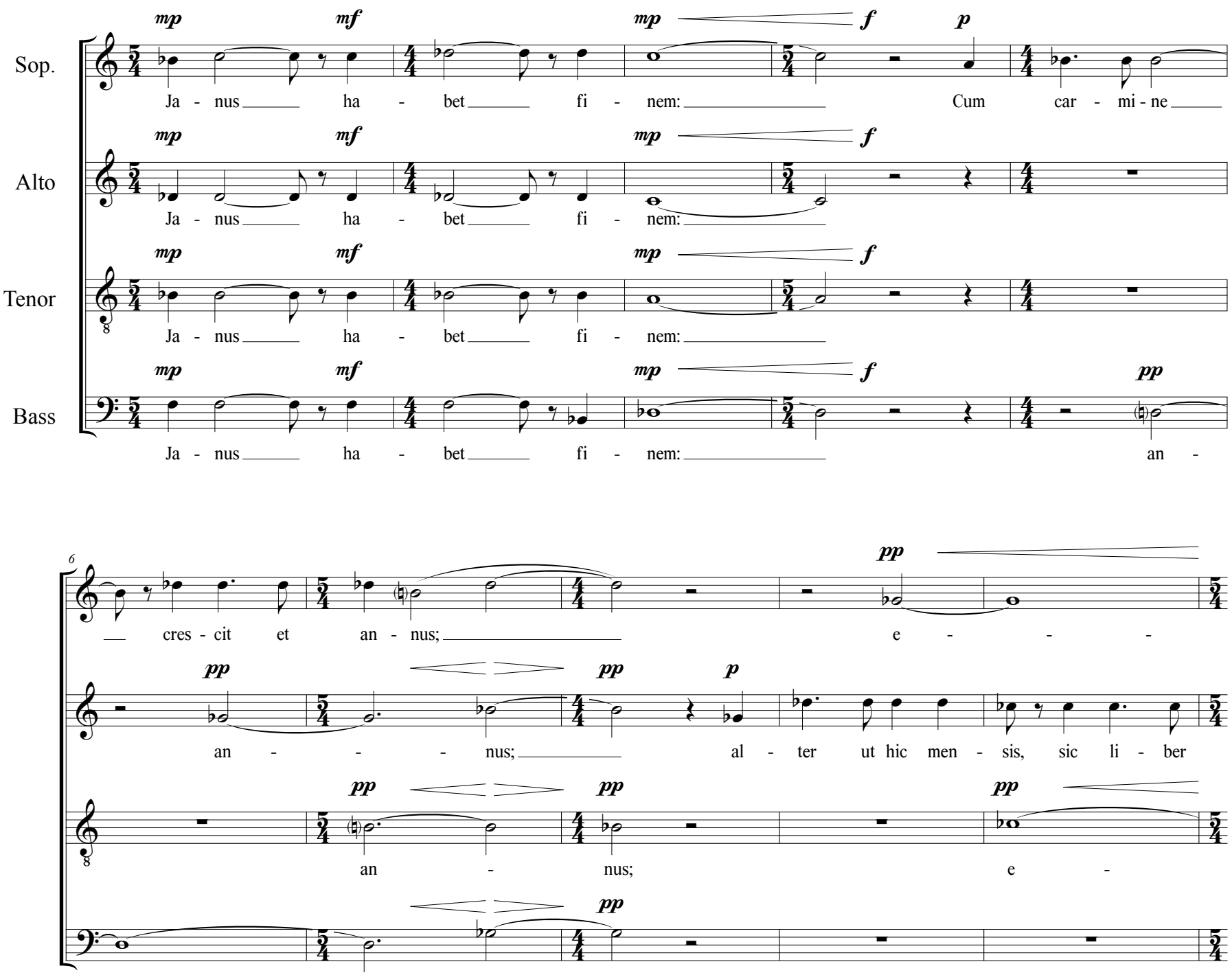

nus;

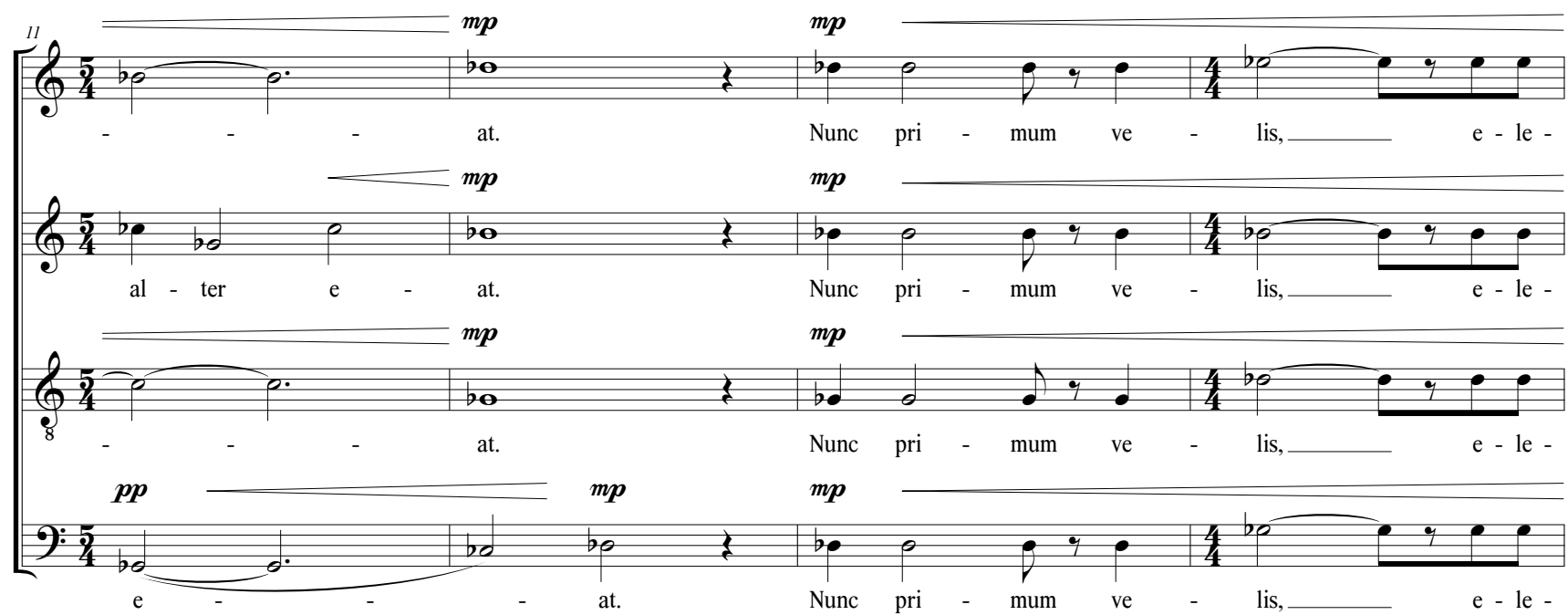



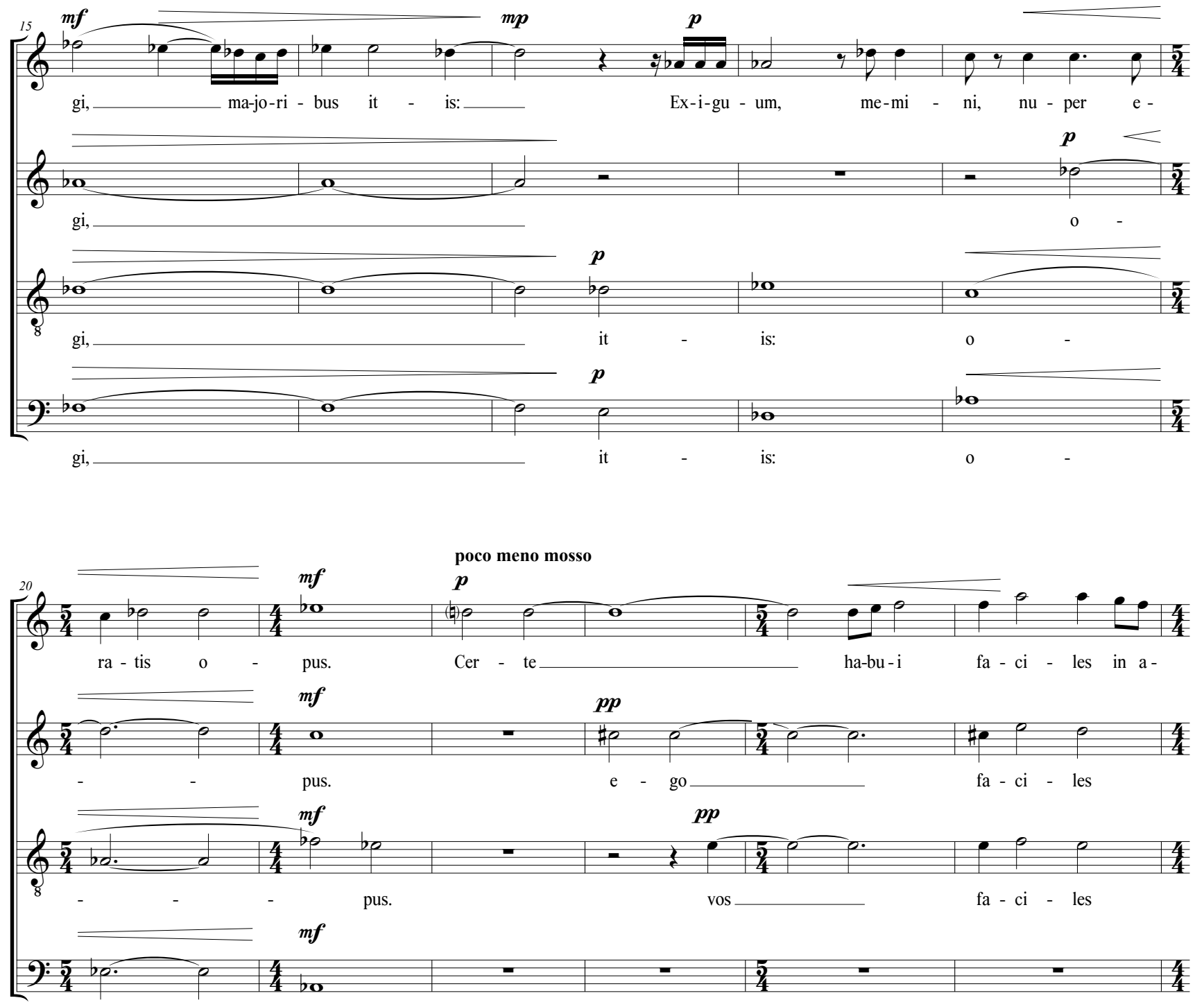

pus.

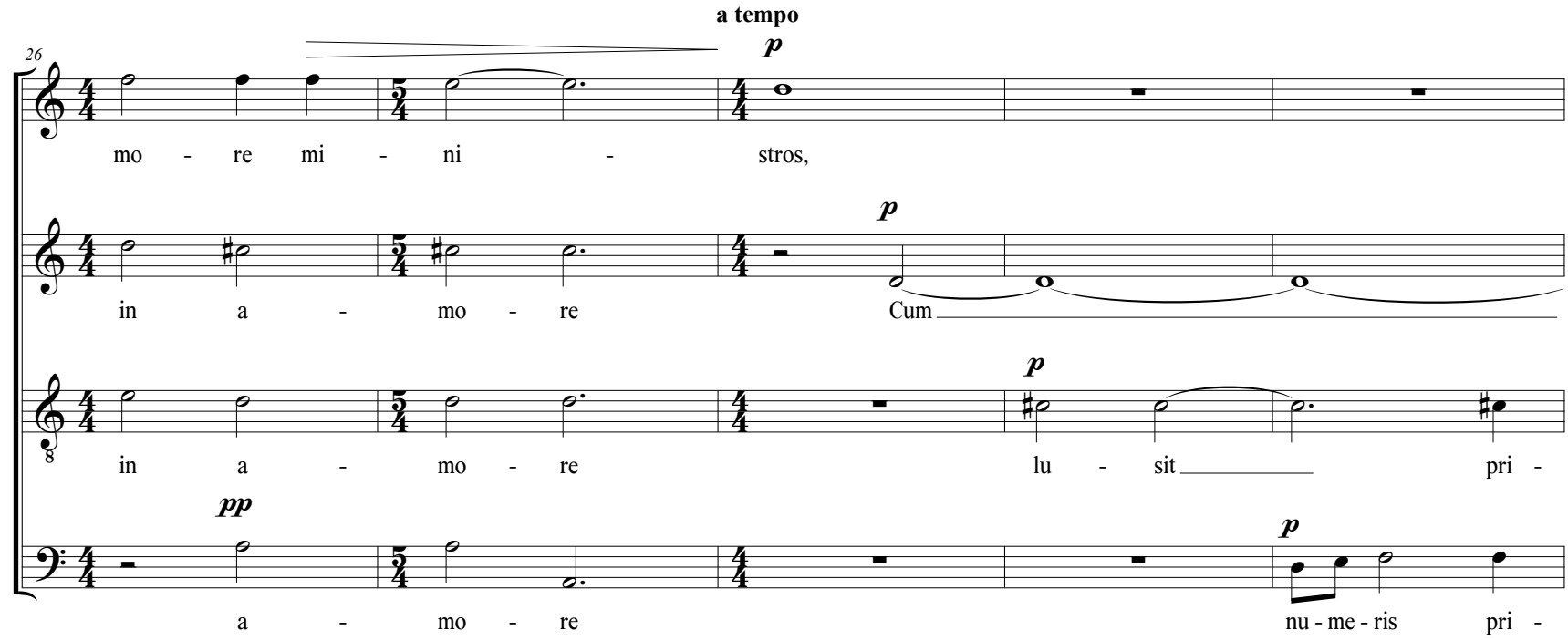



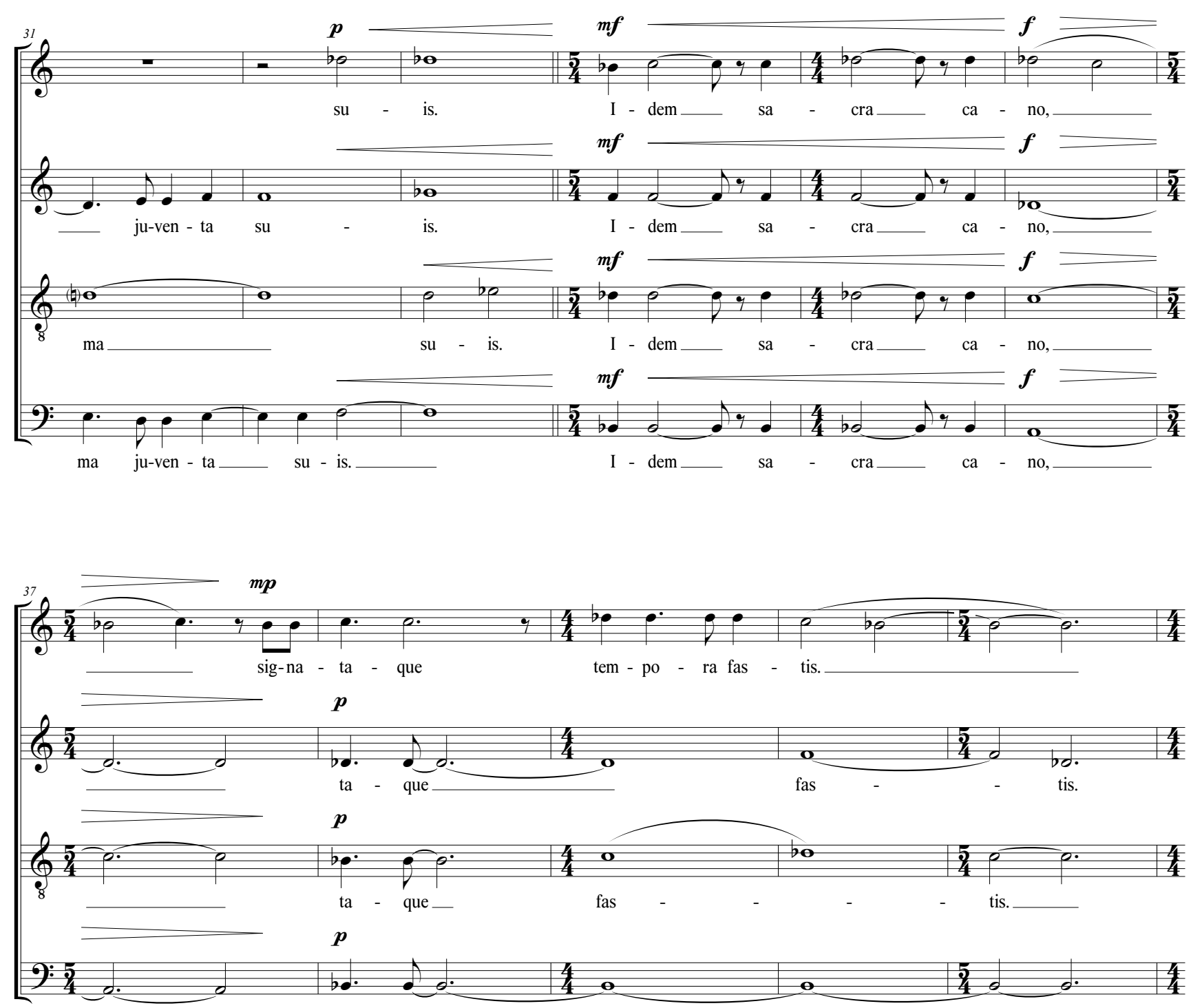

ta - que

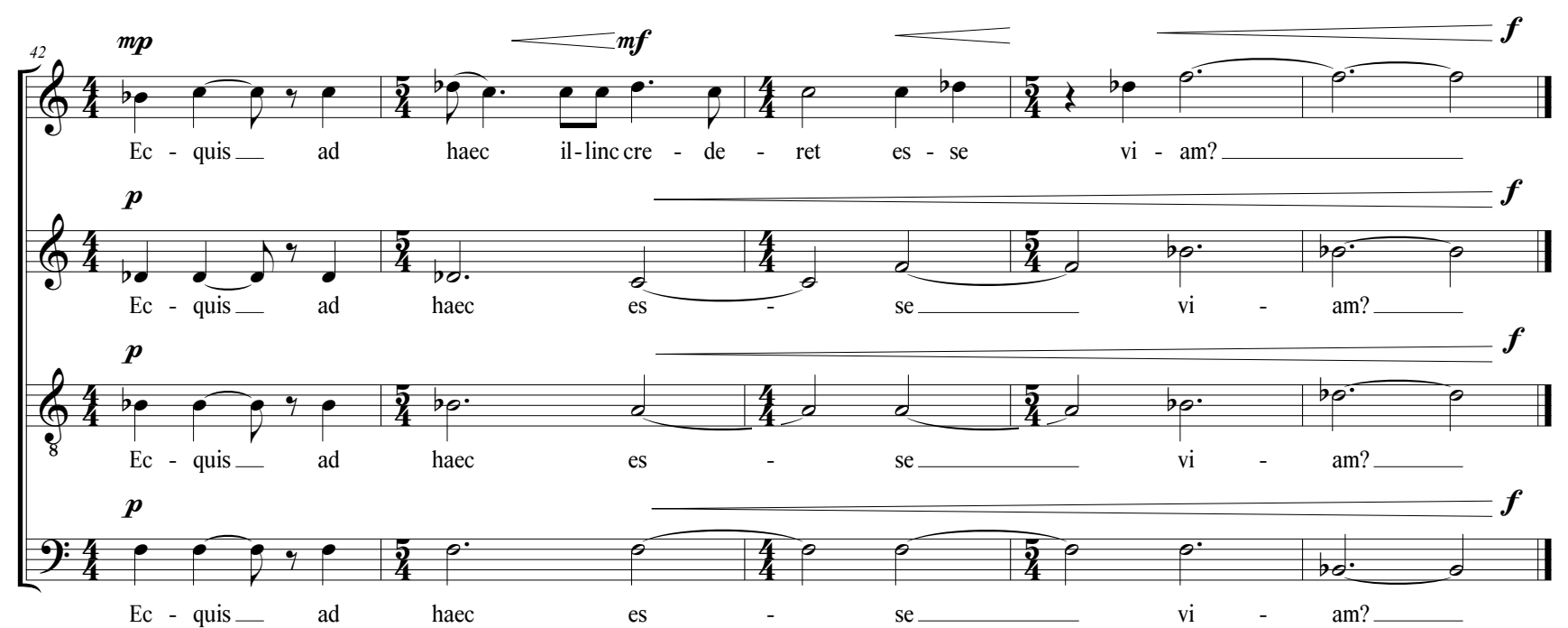





\section{CRANE AND OTTER (2015)}

JAMES A. SKIERKA

STRING QUARTET 


\section{PROGRAM NOTES:}

Crane and Otter is based on a myth of the Assiniboine people, describing how the crane got its black and red markings, and how the otter is able to live underwater during the winter.

In the myth, Mother Crane asks Otter to look after her child, as it is too weak to fly south for the winter with the rest of the cranes. Otter accepts the offer, and is promised he will be rewarded in the spring, when Mother Crane returns. The Cold, personified by the god Osni', comes to Otter's home and kidnaps Young Crane, killing Otter in the process. Young Crane is held captive by Osni' for the remainder of the winter, forced to stir and stoke the fire, becoming burnt and covered in soot. This is how the crane received its red and black markings.

When spring drew near, Young Crane tried to escape and call for its mother, knowing she would return soon. Osni' tries to stop Young Crane from doing so, and is struck by lightning in the process. When Mother Crane returns, she is reunited with Young Crane. After hearing his story, Mother Crane went to visit the rest of the otters, and rewarded all of them with a thick coat of fur. This is how the otter is able to live in the water without freezing. 


\section{PERFORMANCE NOTES:}

The Violin I part contains a large section of pizzicato playing. While this is notated fairly precisely in the score, a certain amount of freedom can be taken by the performer to add to the idea of playfulness (giocoso).

In bar 8, Violin I, I have indicated that there should be a poco accel. with the grouping of four notes at the end of the measure. This only applies to that grouping of notes, not the preceding or following notes. This occurs in Measures 16 and 17, as well.

Bars 11 and 83 contain a poco rit., instead of a poco accel., for the grouping of four notes. As with the poco accel., this only applies to the grouping of four notes, and not with the notes preceding or following it.

Some notes are indicated to be held for a length of time that might be longer then is possible with the instrument. If you must change your bowing, try to do so with as little interruption in the sound as possible.

Diminuendos leading to a rest should be interpreted as going to niente.

Bars 62-65 contain the instructions poco accel. con cresc. and poco rit. con dim.. The instructions are purposely offset between the instruments, and the notation, while in triplets, should become disjointed and out of sync. They should fall inline again in bar 66. In bars 68-70, a similar effect should occur.

Bar 85 contains the instruction rit. e dim. al fine. While observing the dynamic markings in the individual parts, there should be an overall effect of slowing down, and fading away. 



\section{Crane and Otter}

James A. Skierka
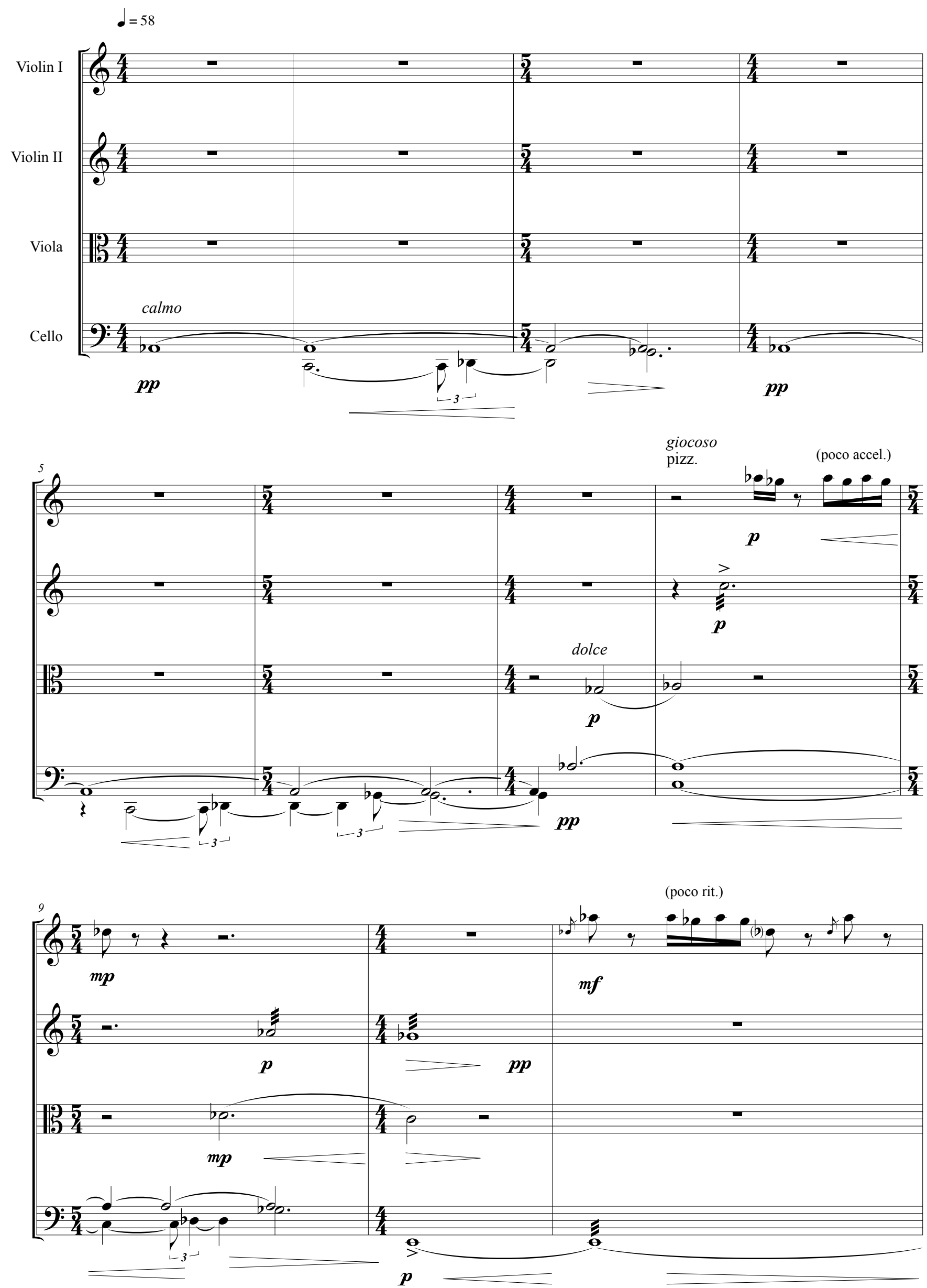

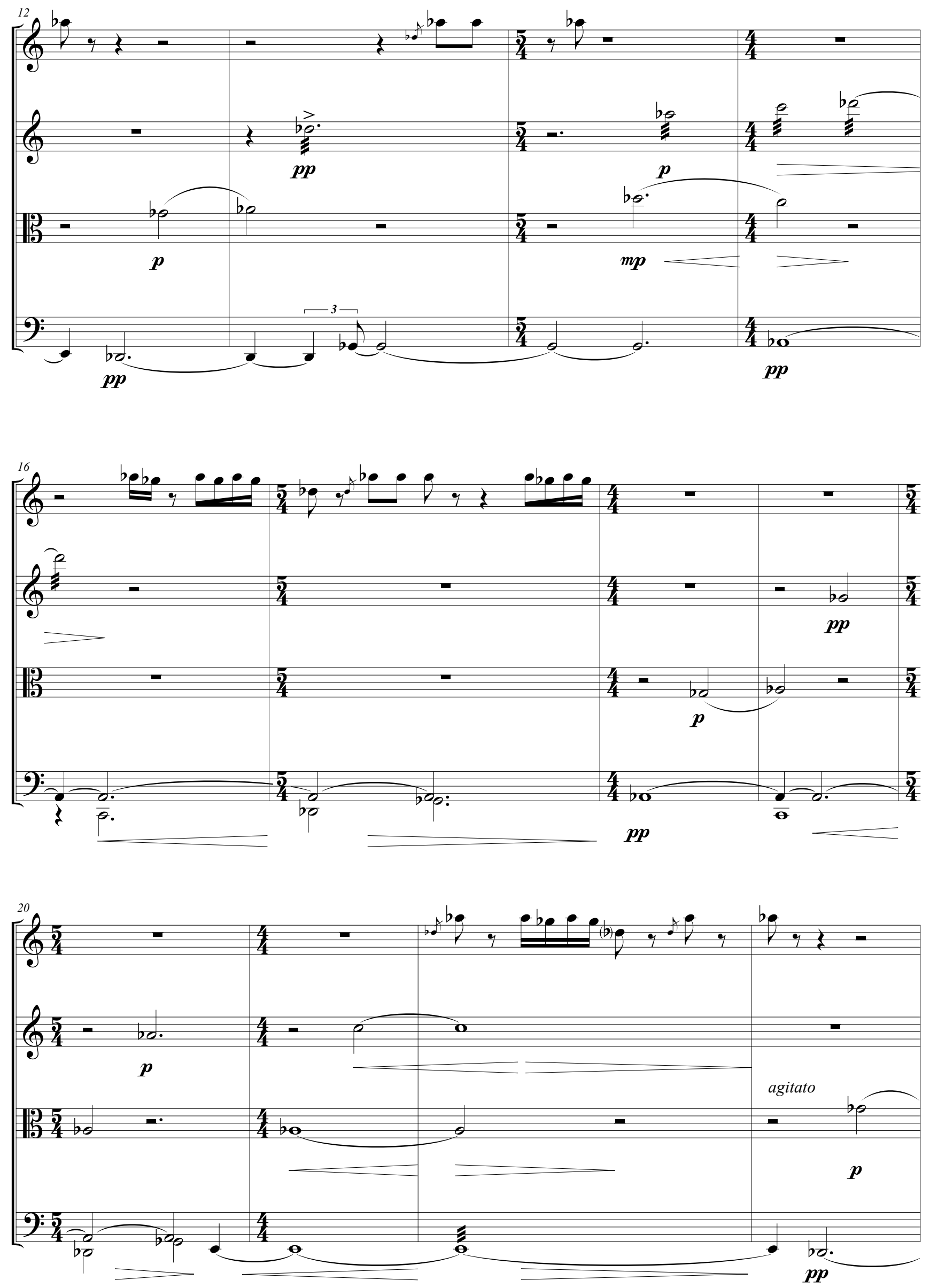

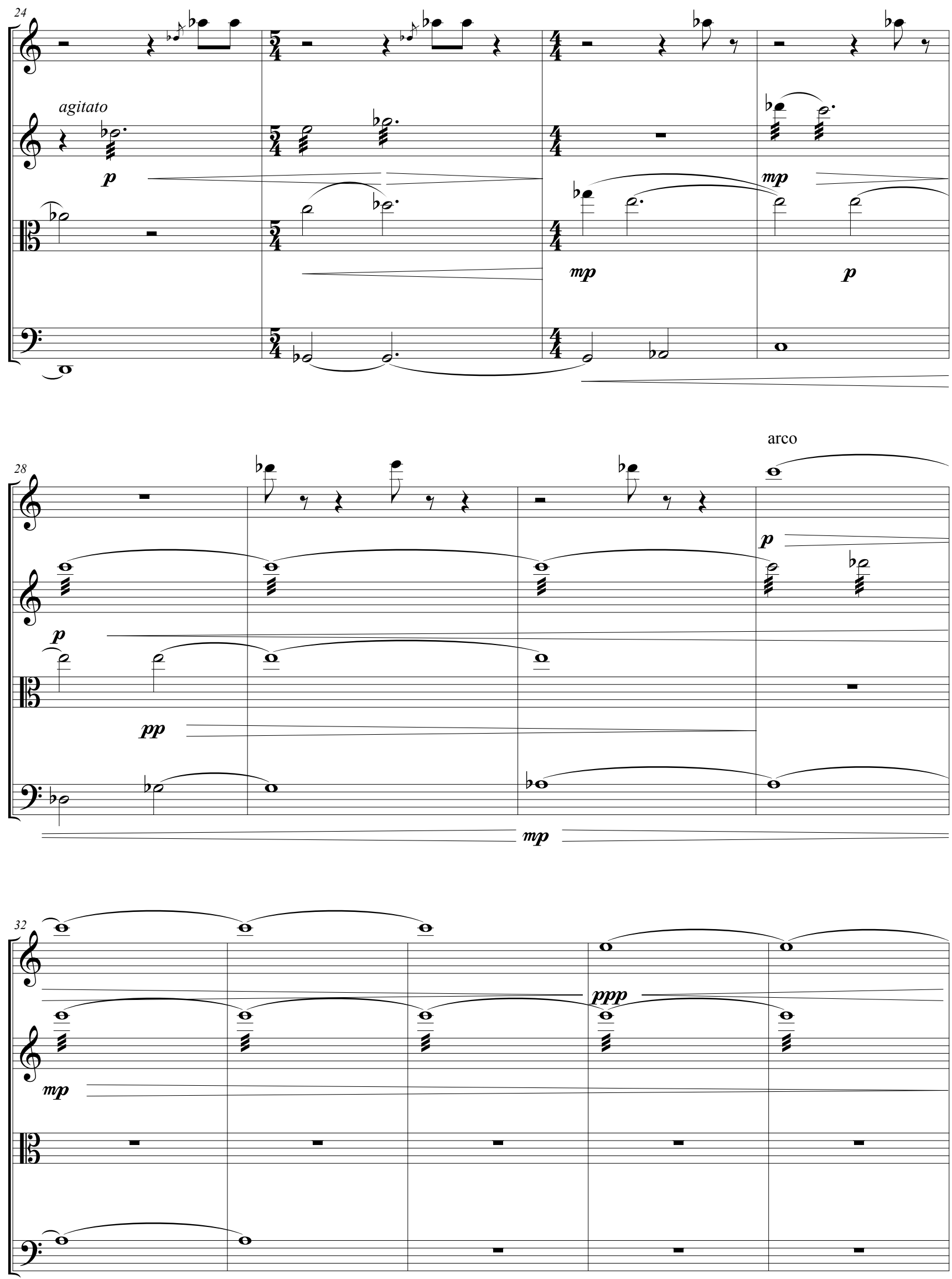

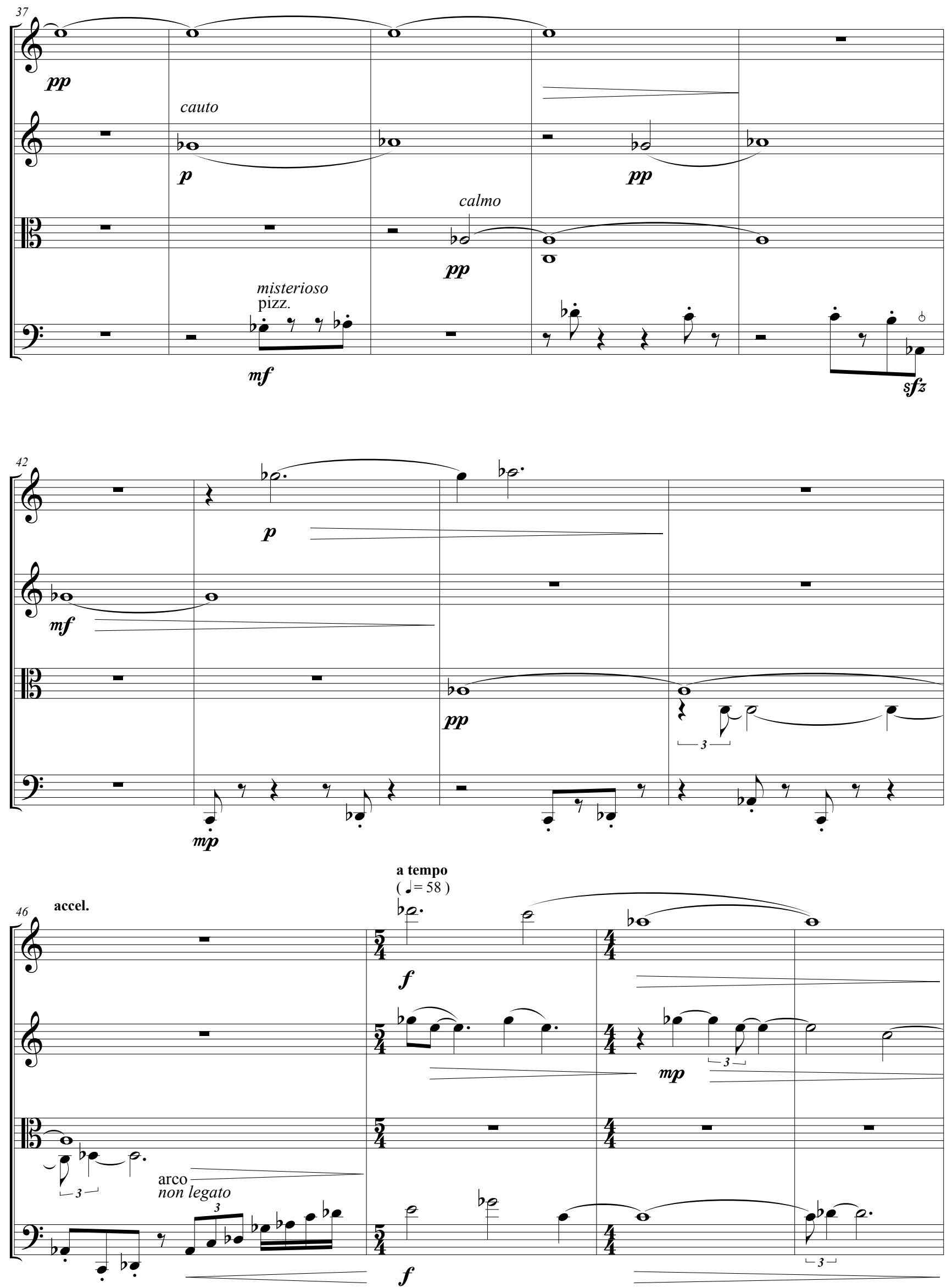
Crane and Otter

43
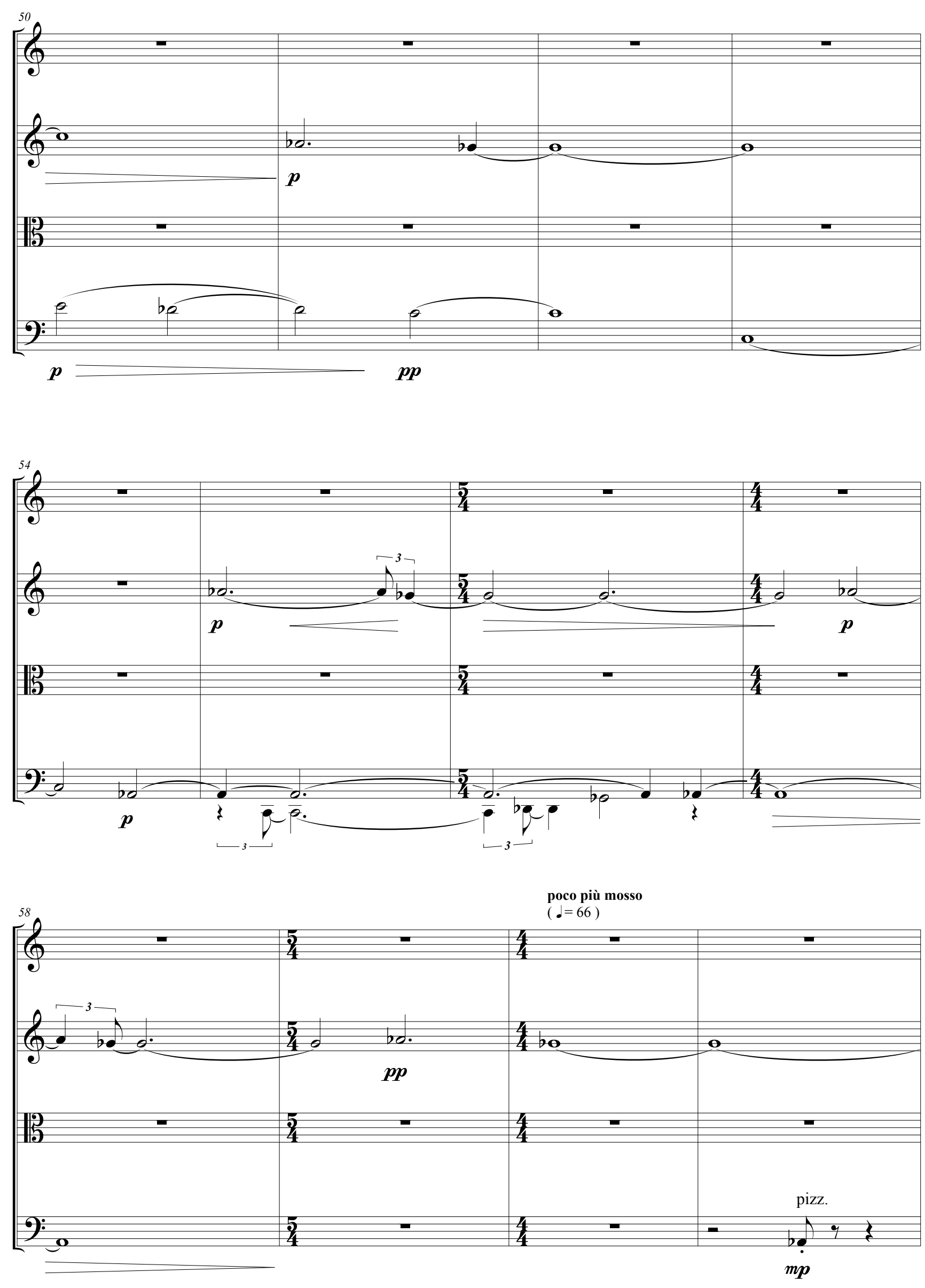

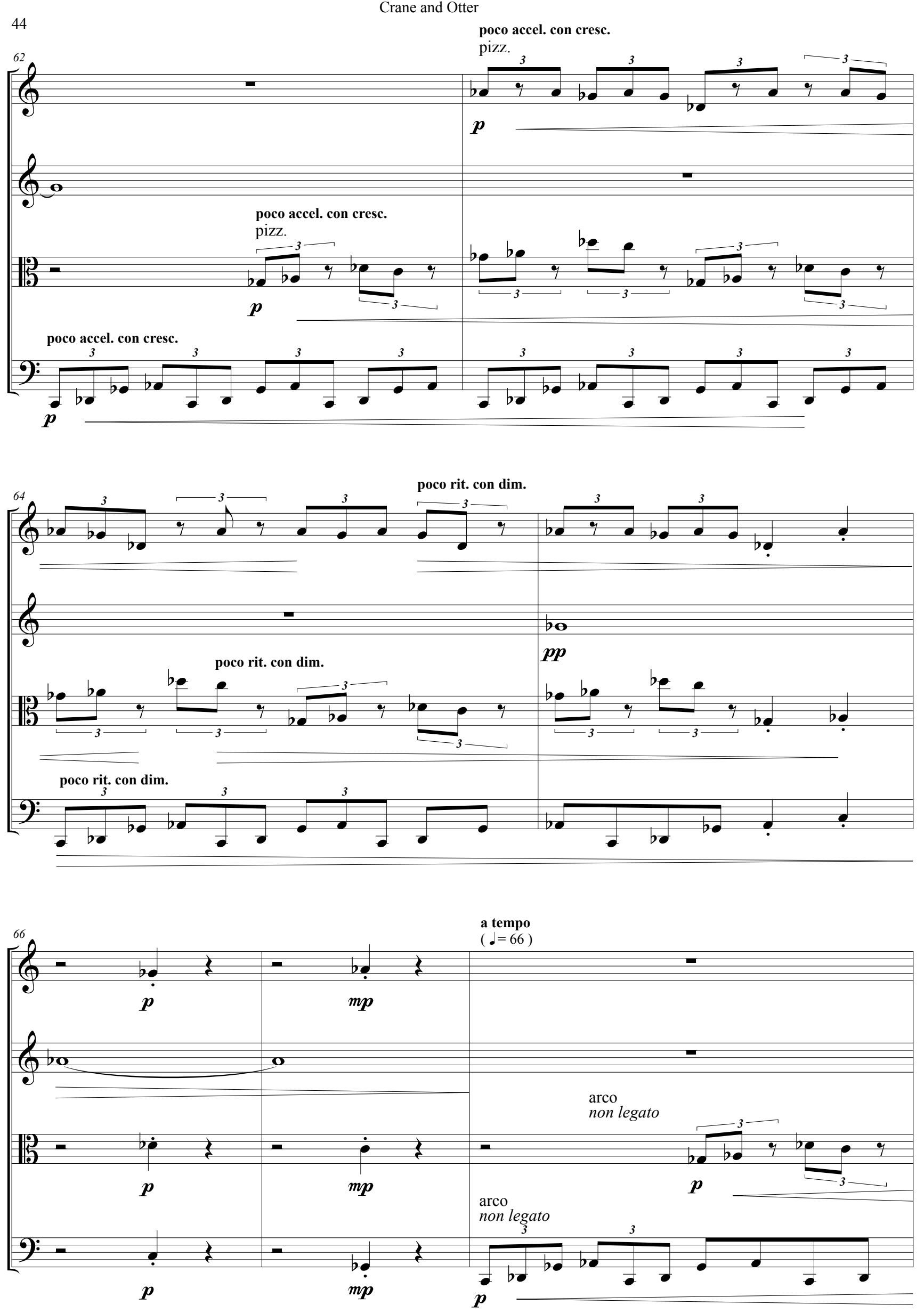

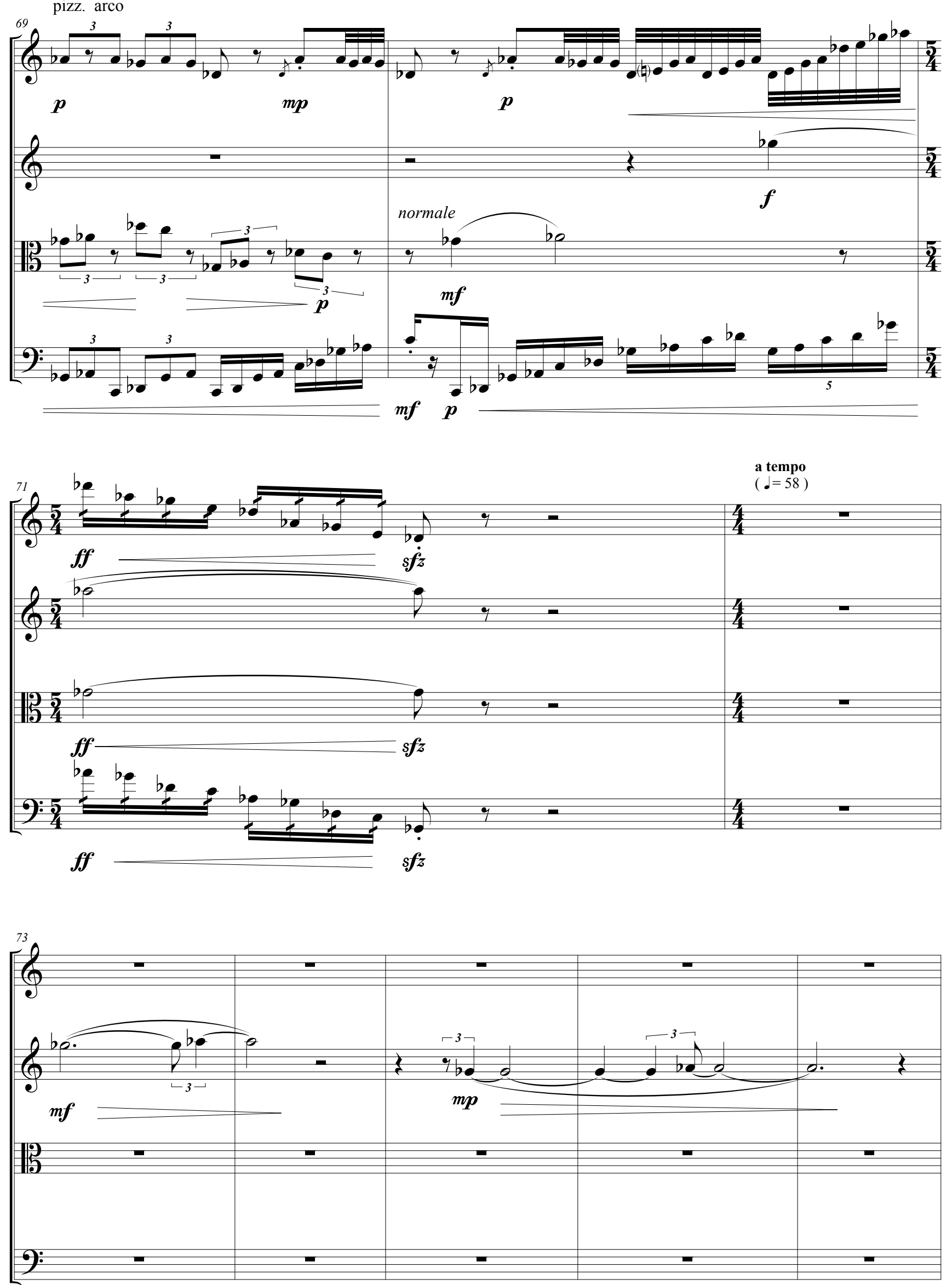

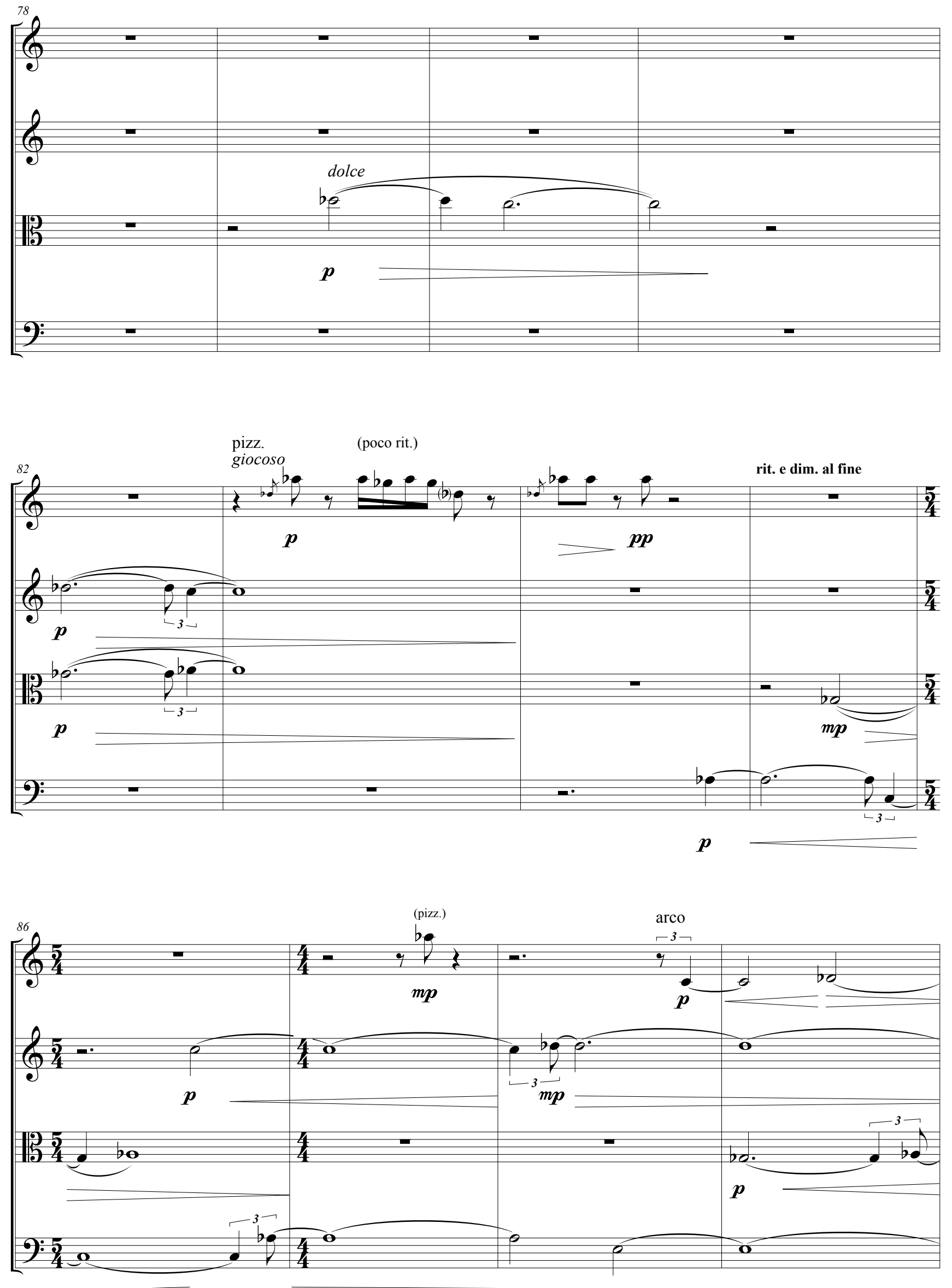

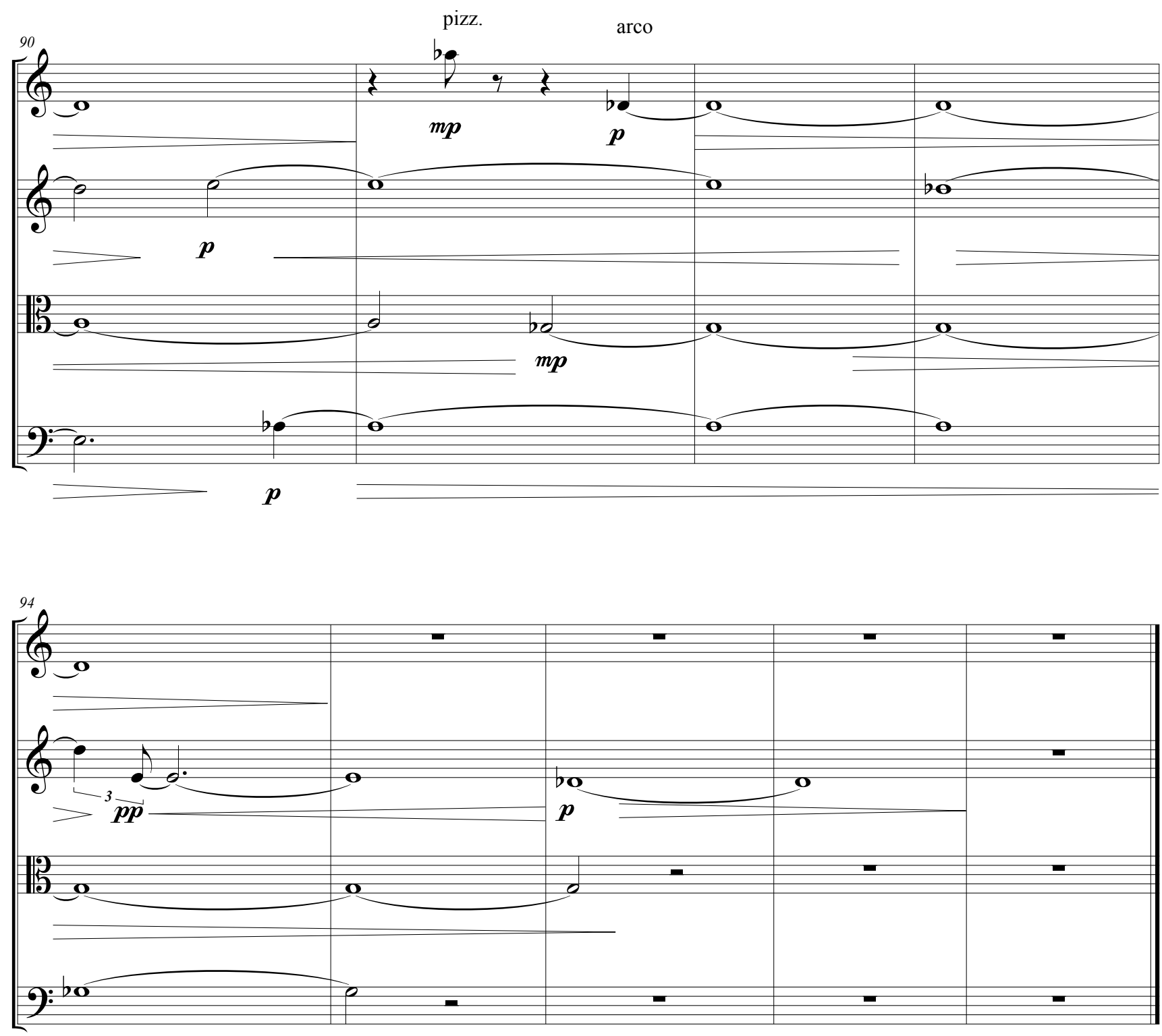

(ca. 7' 00") 



\section{UN TRAJET INTÉRIEUR (2016)}

JAMES A. SKIERKA 


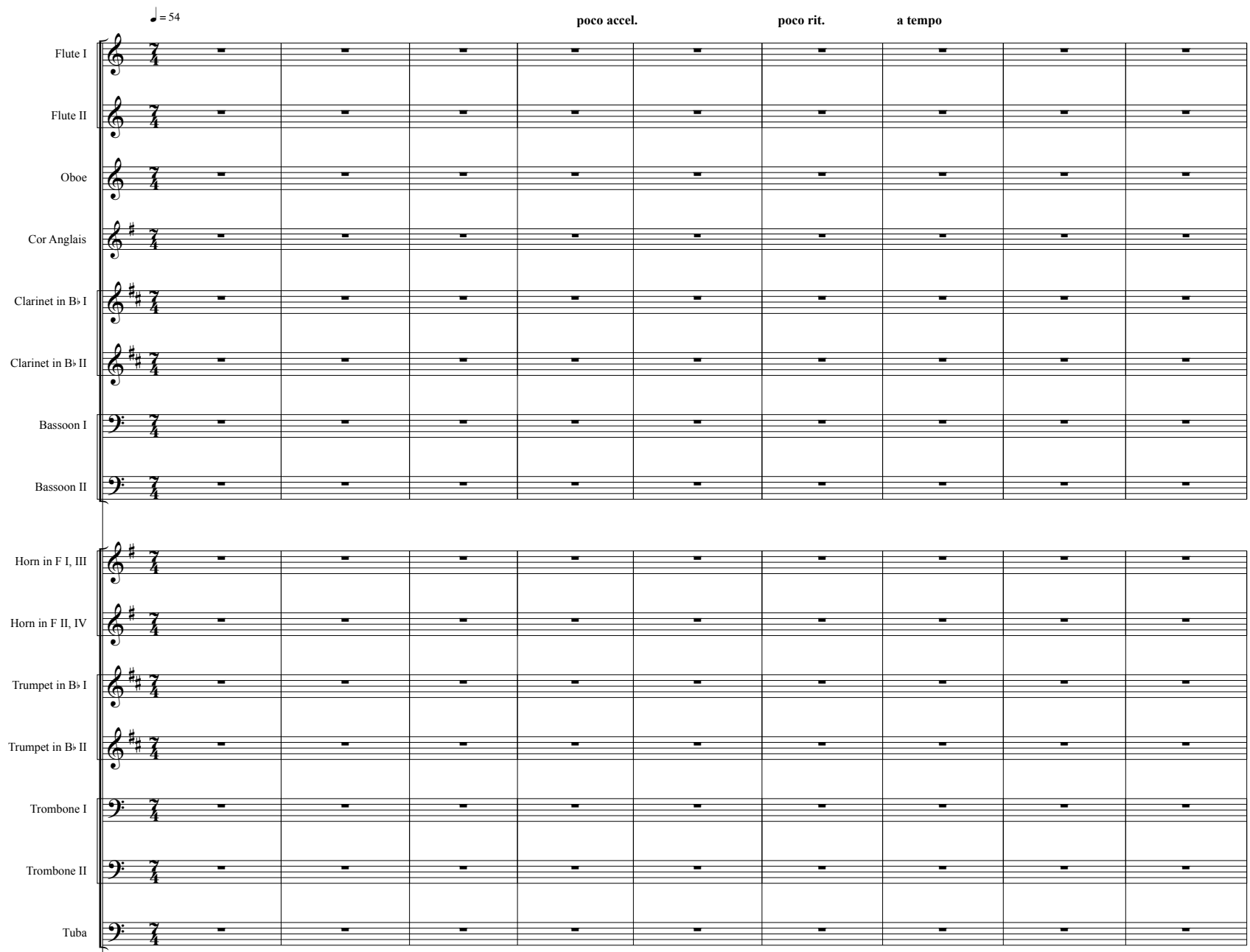

Timpani $\sum_{2}^{2}=$
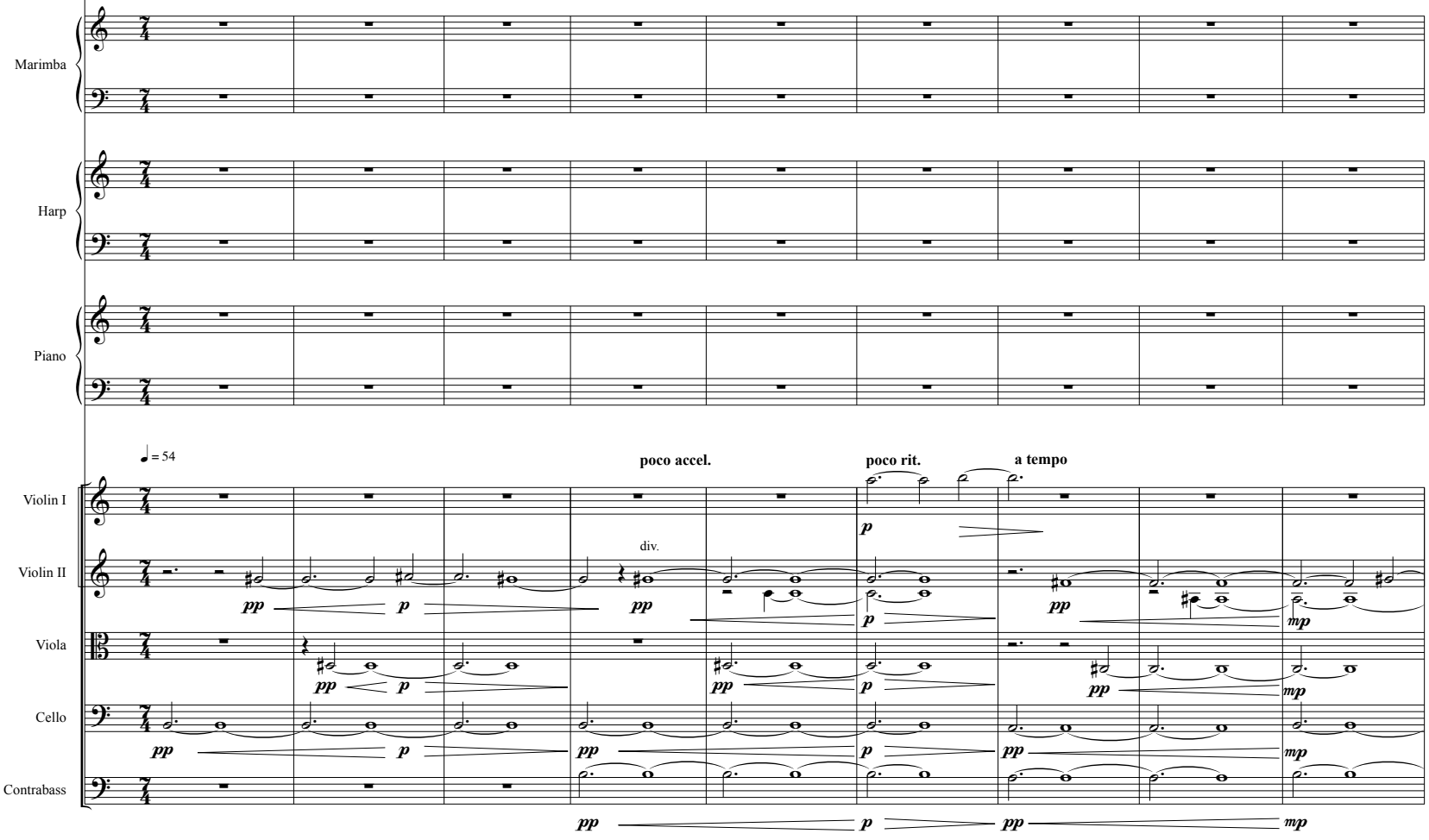

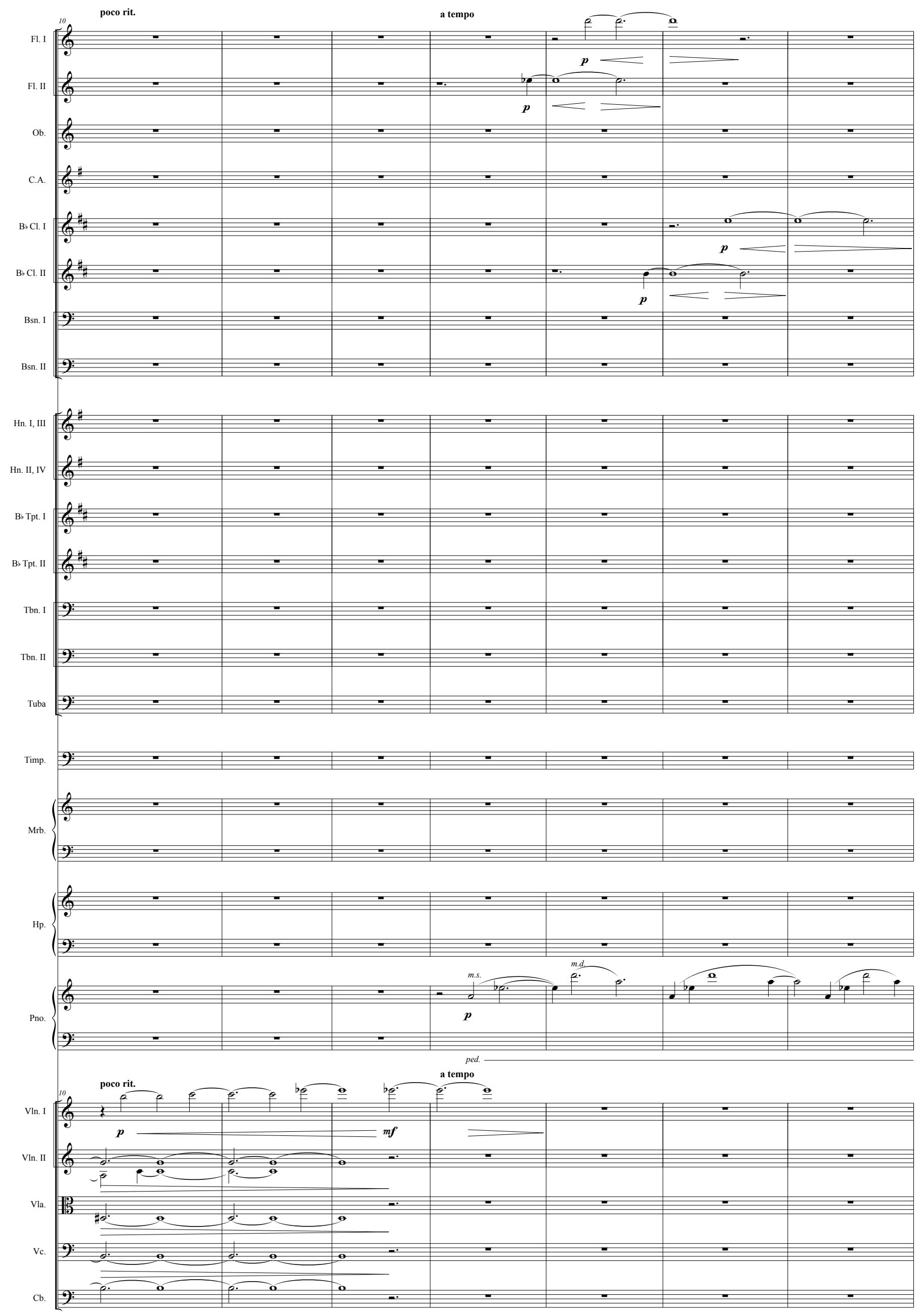

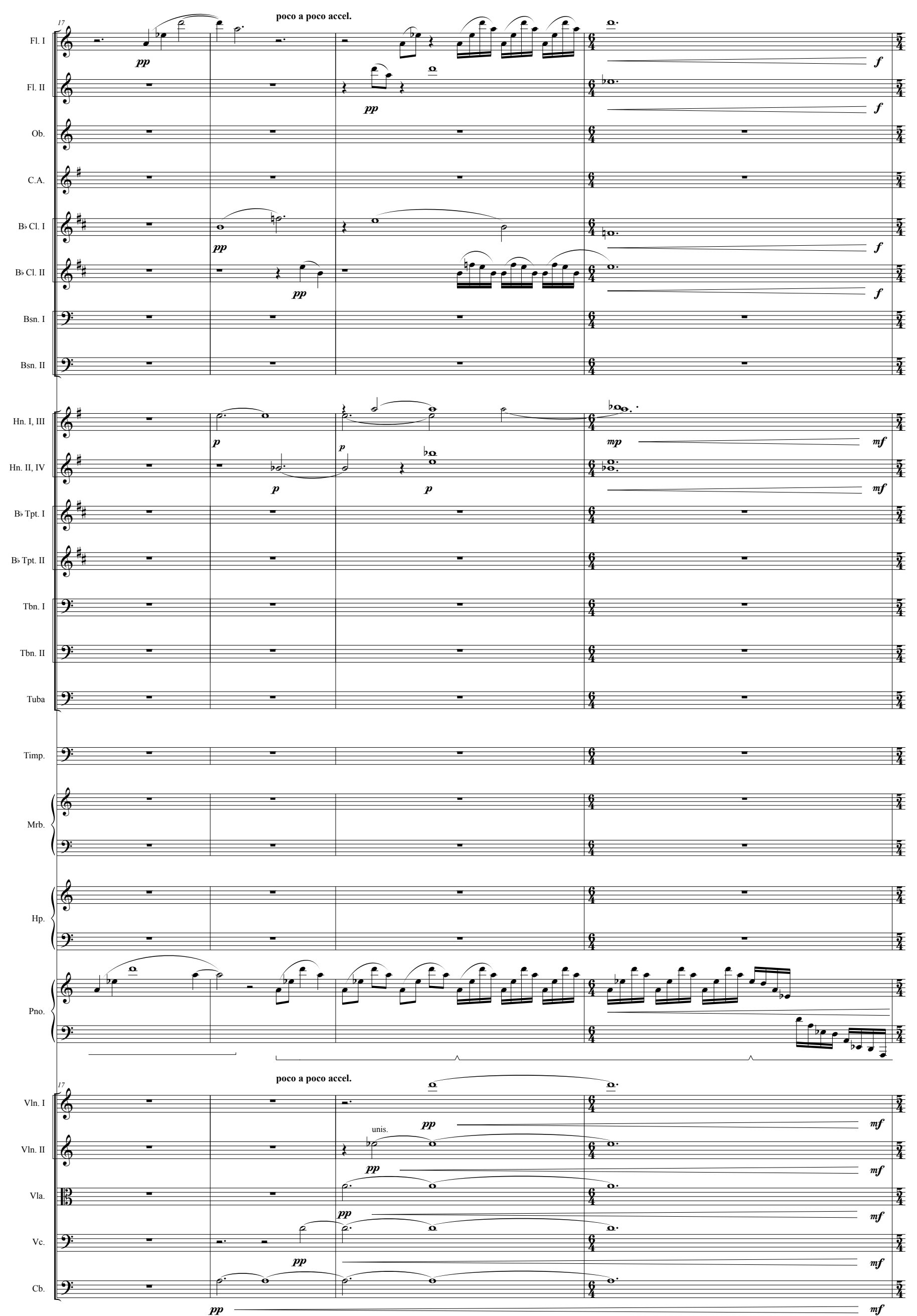


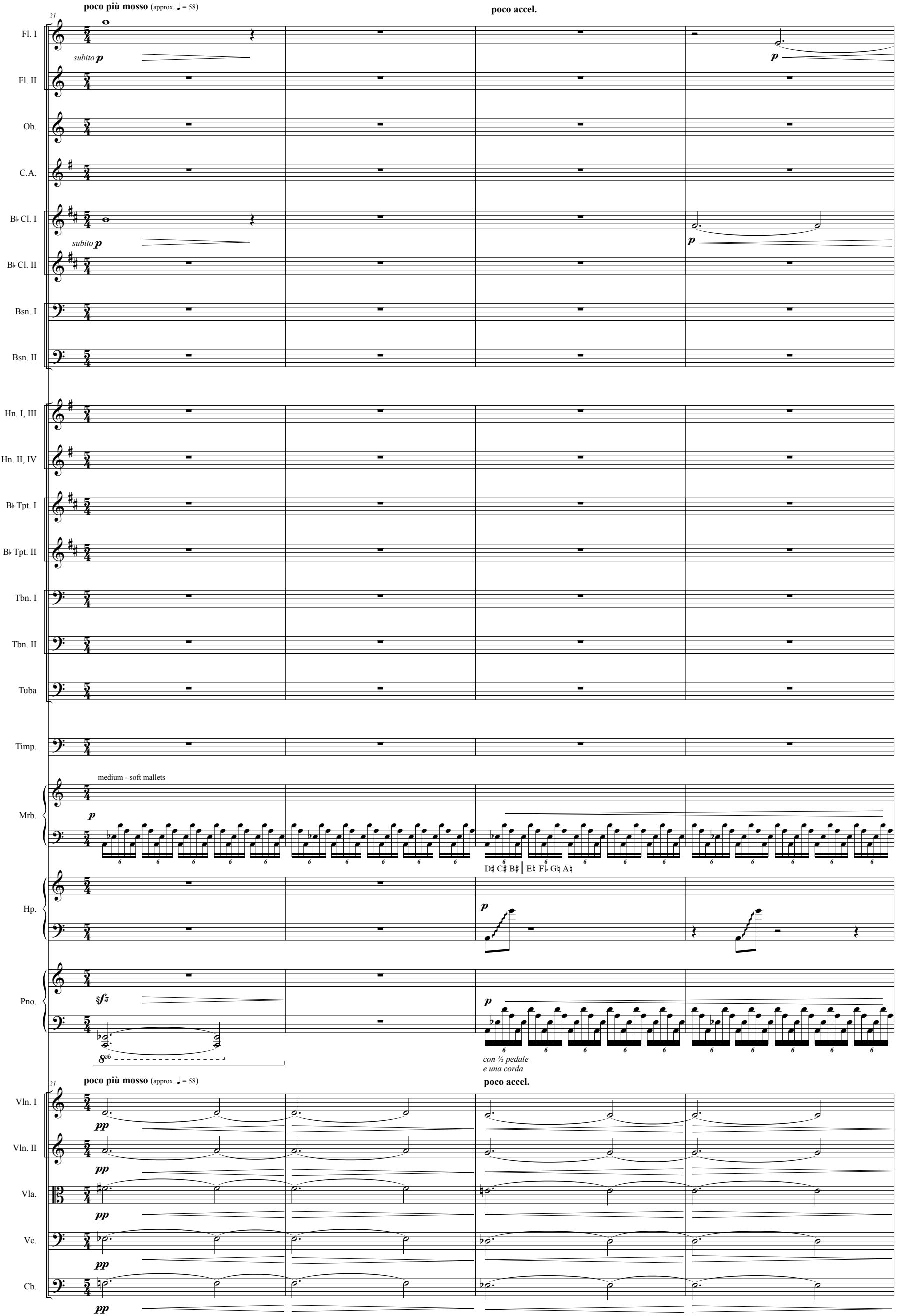




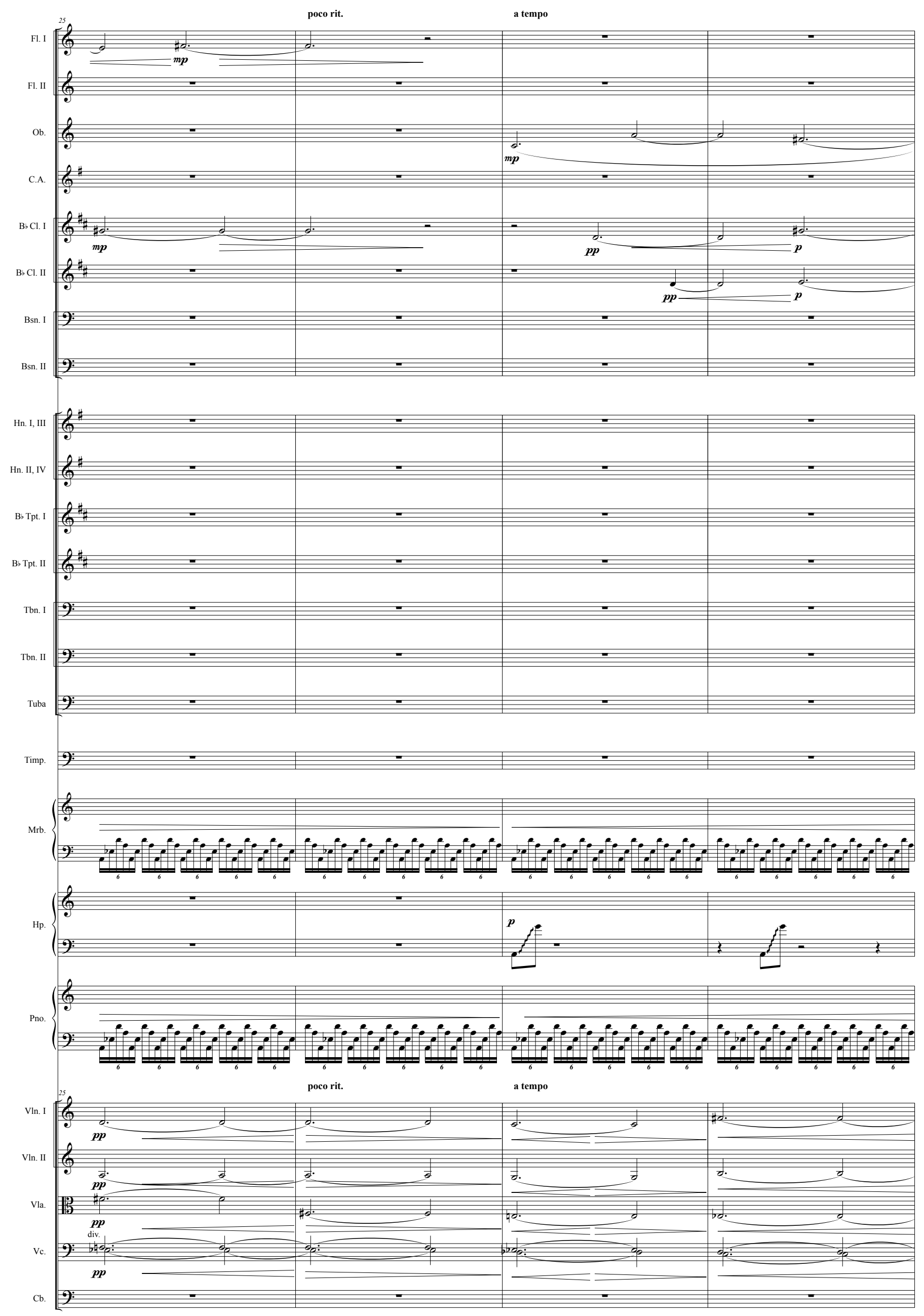



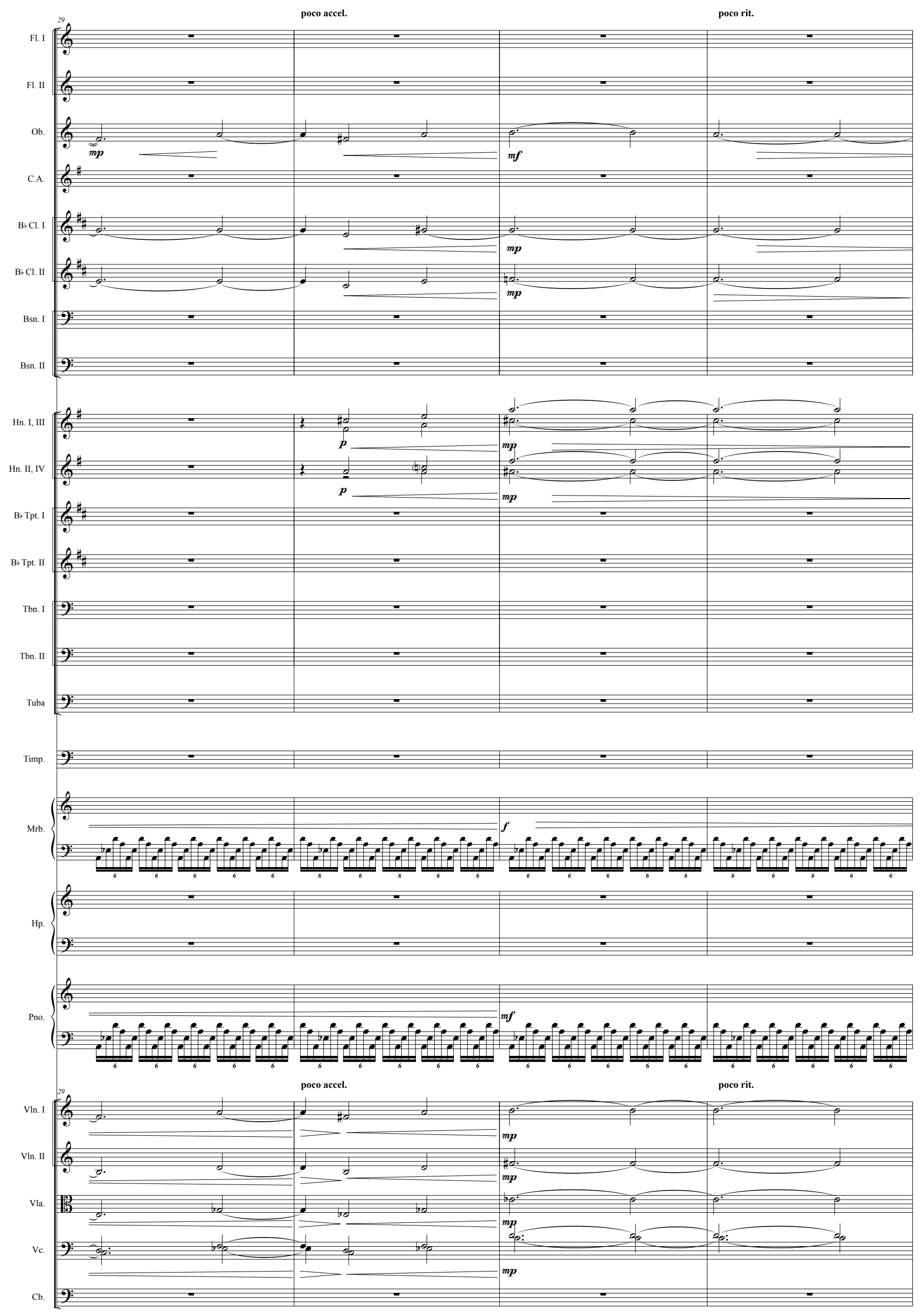

poco rit. 


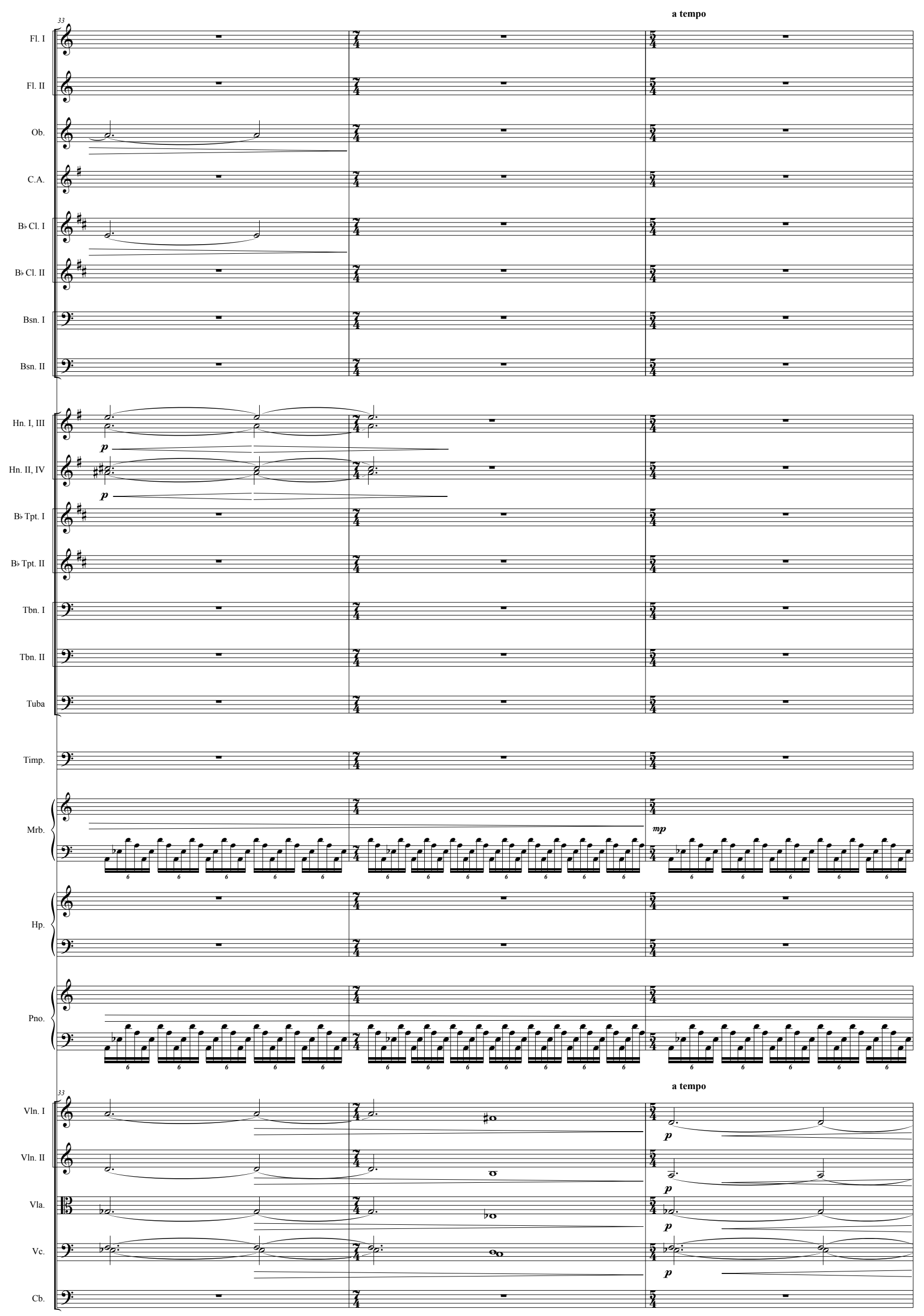



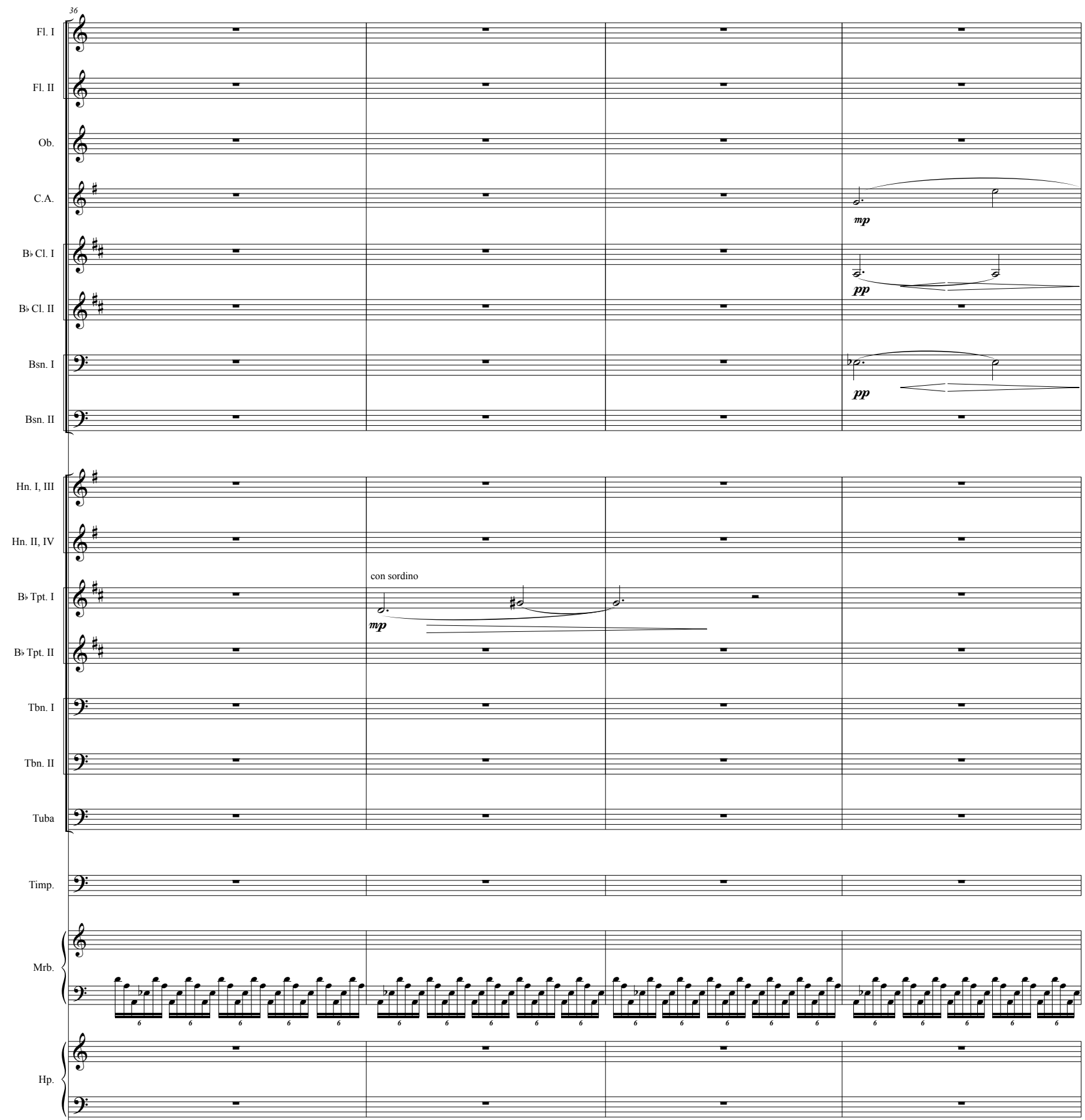

Pno. \{
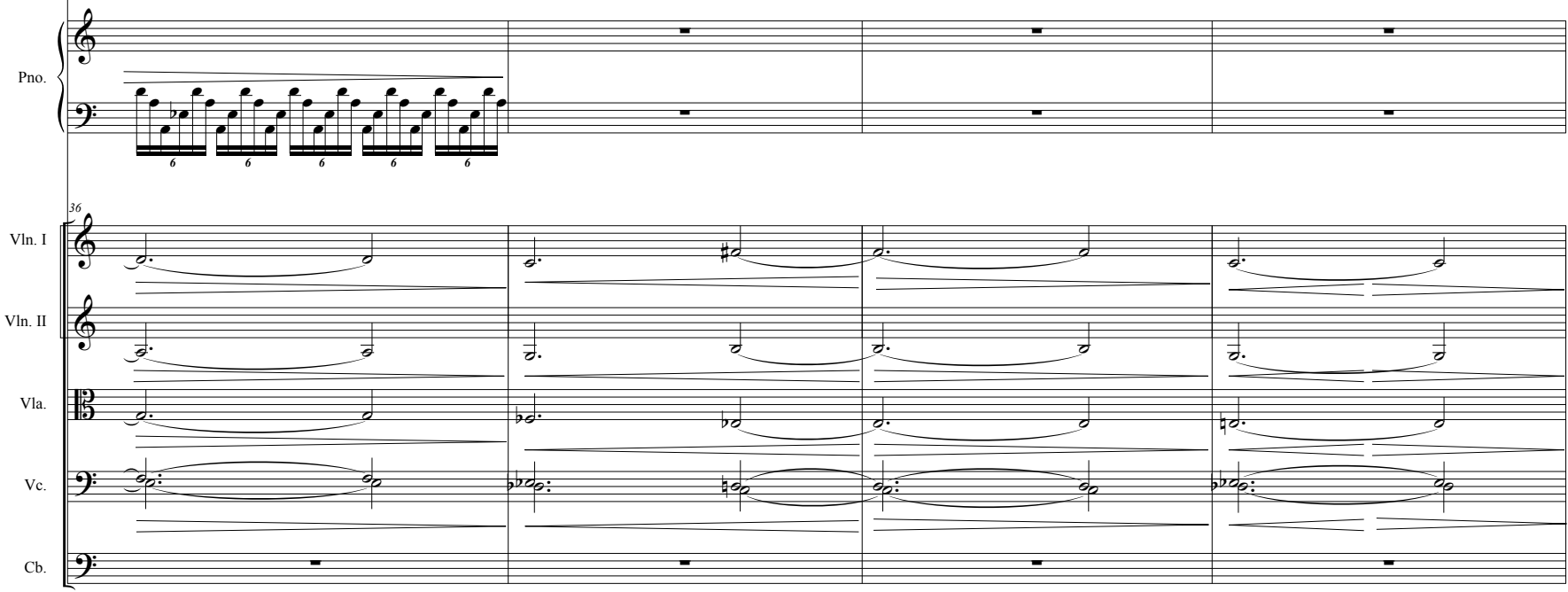

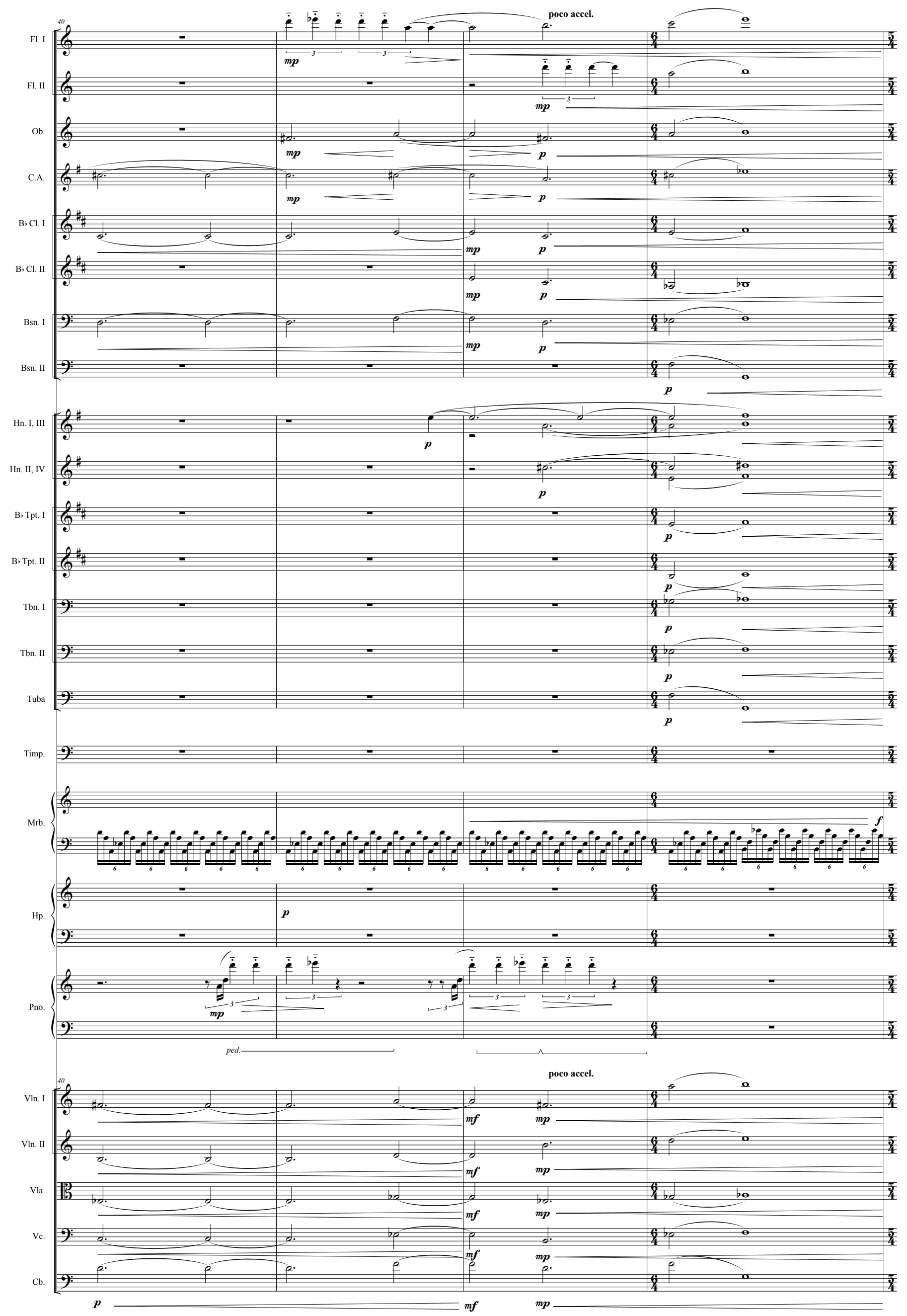


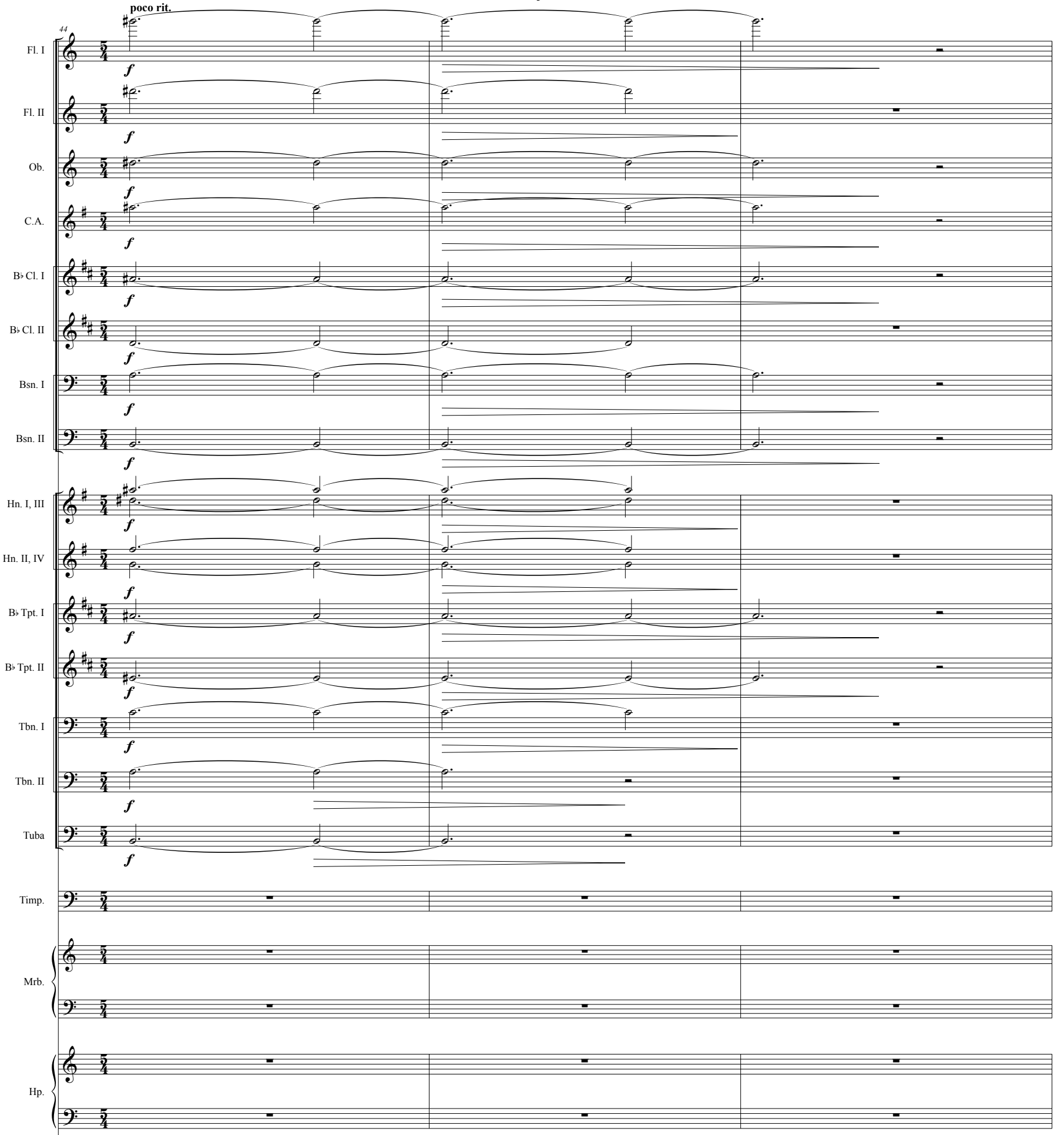

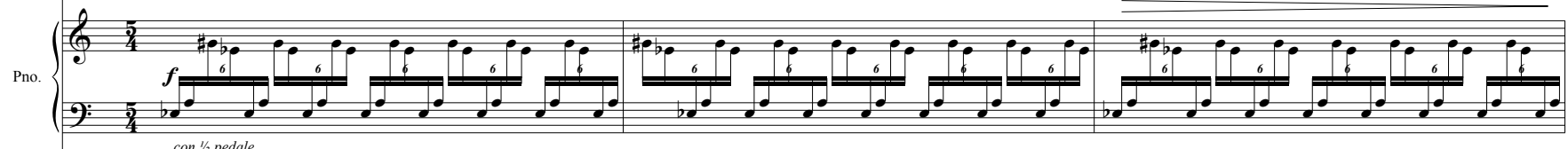
conn'p pedale
euna corda

VIn. II 


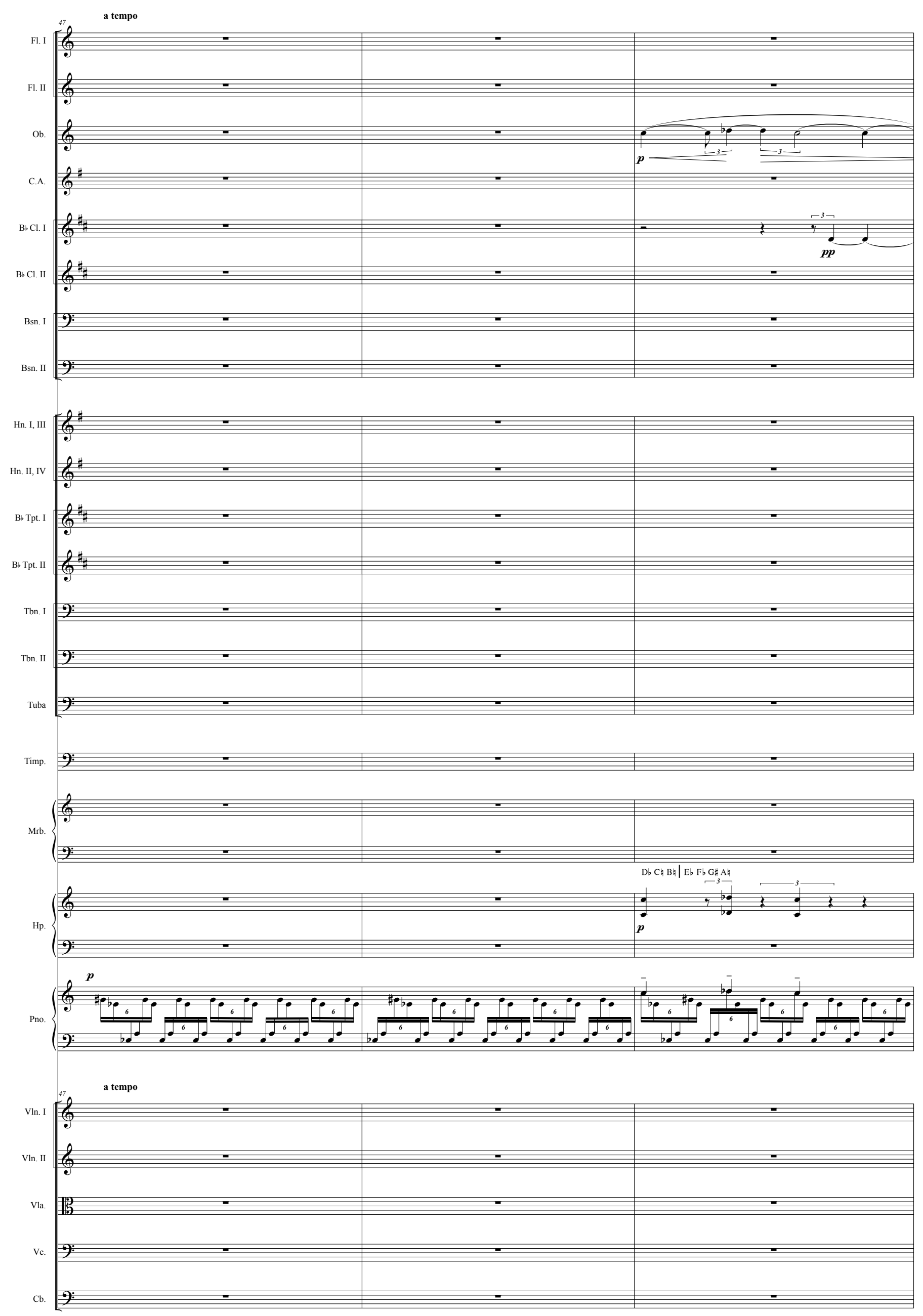



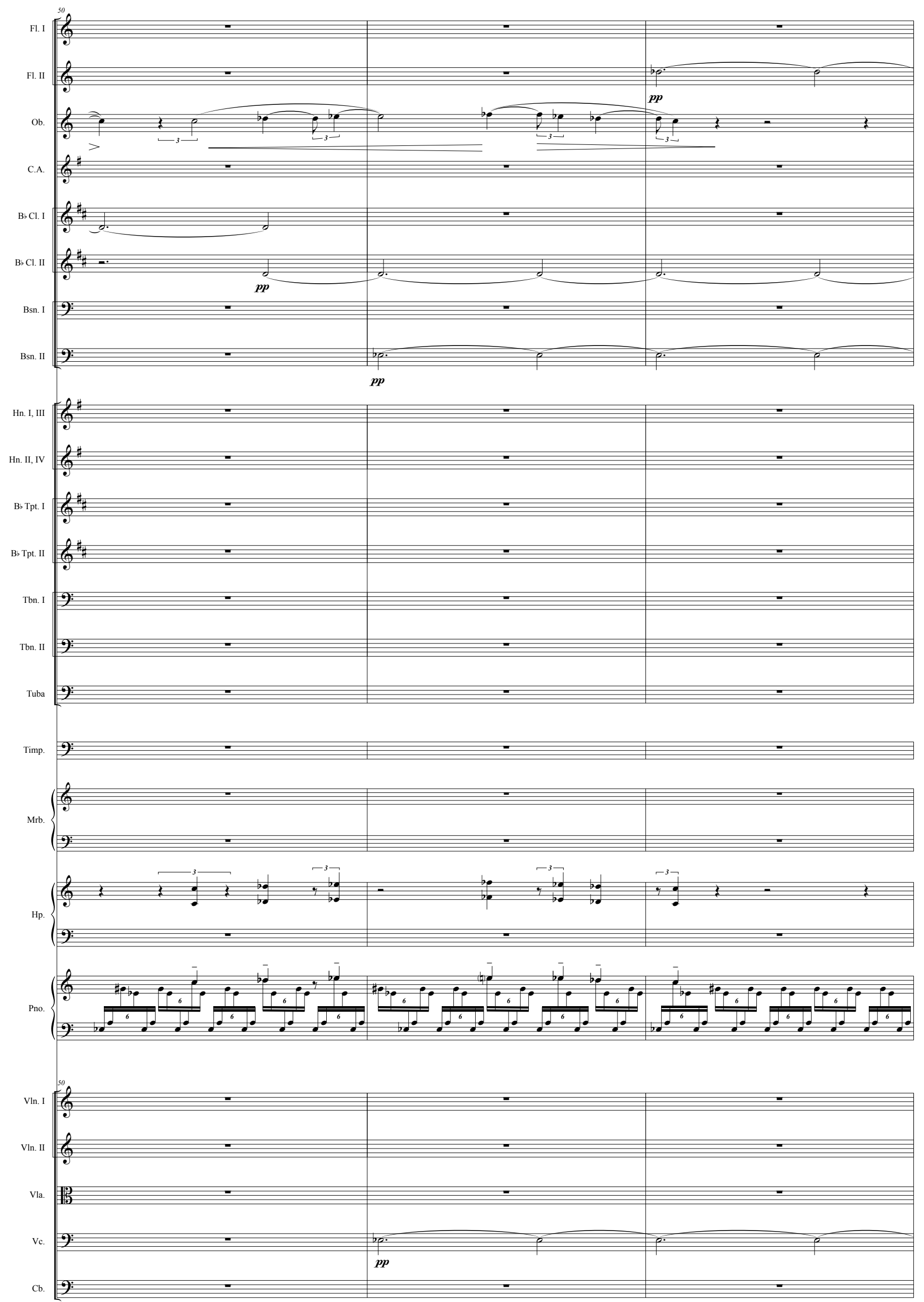


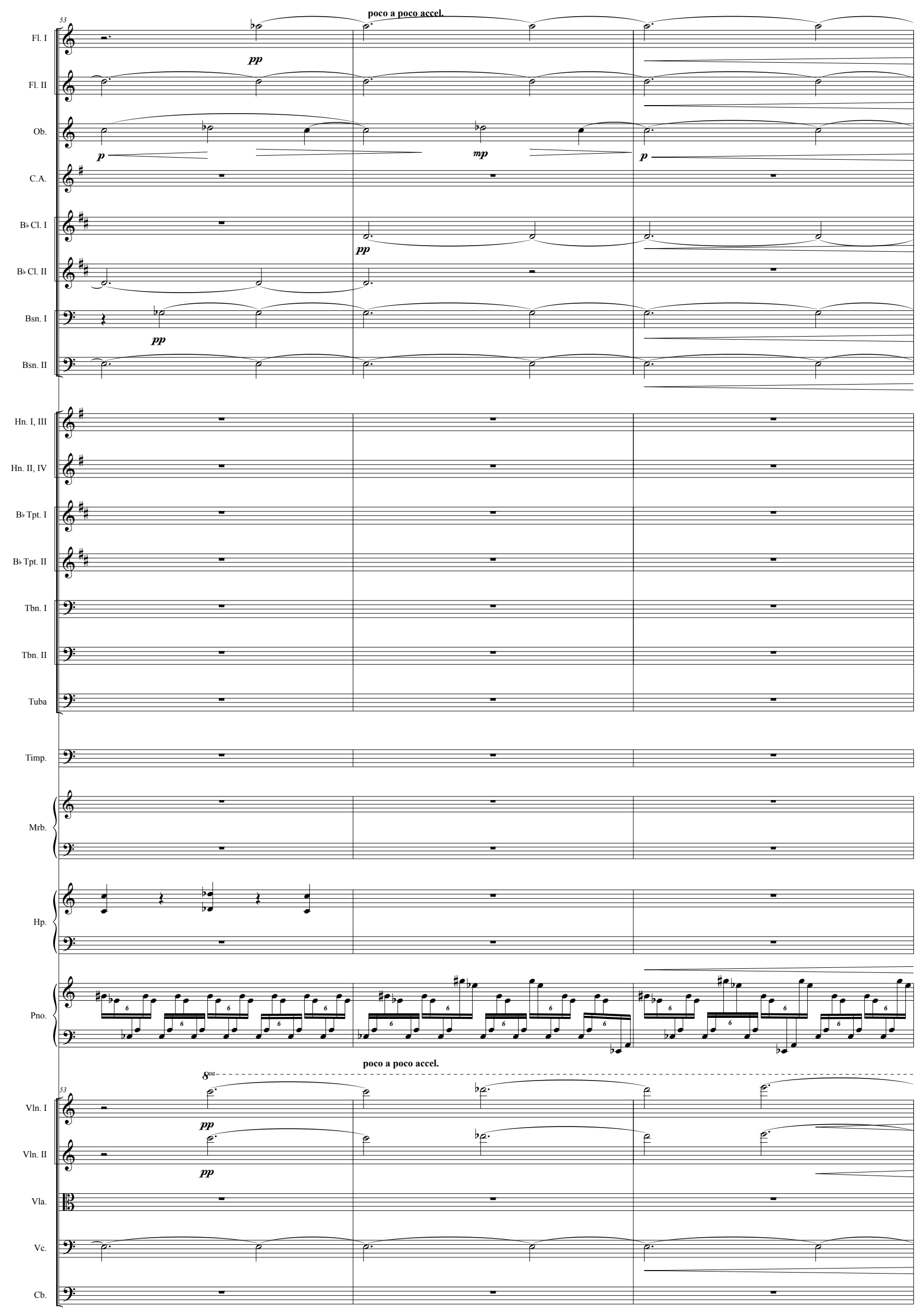




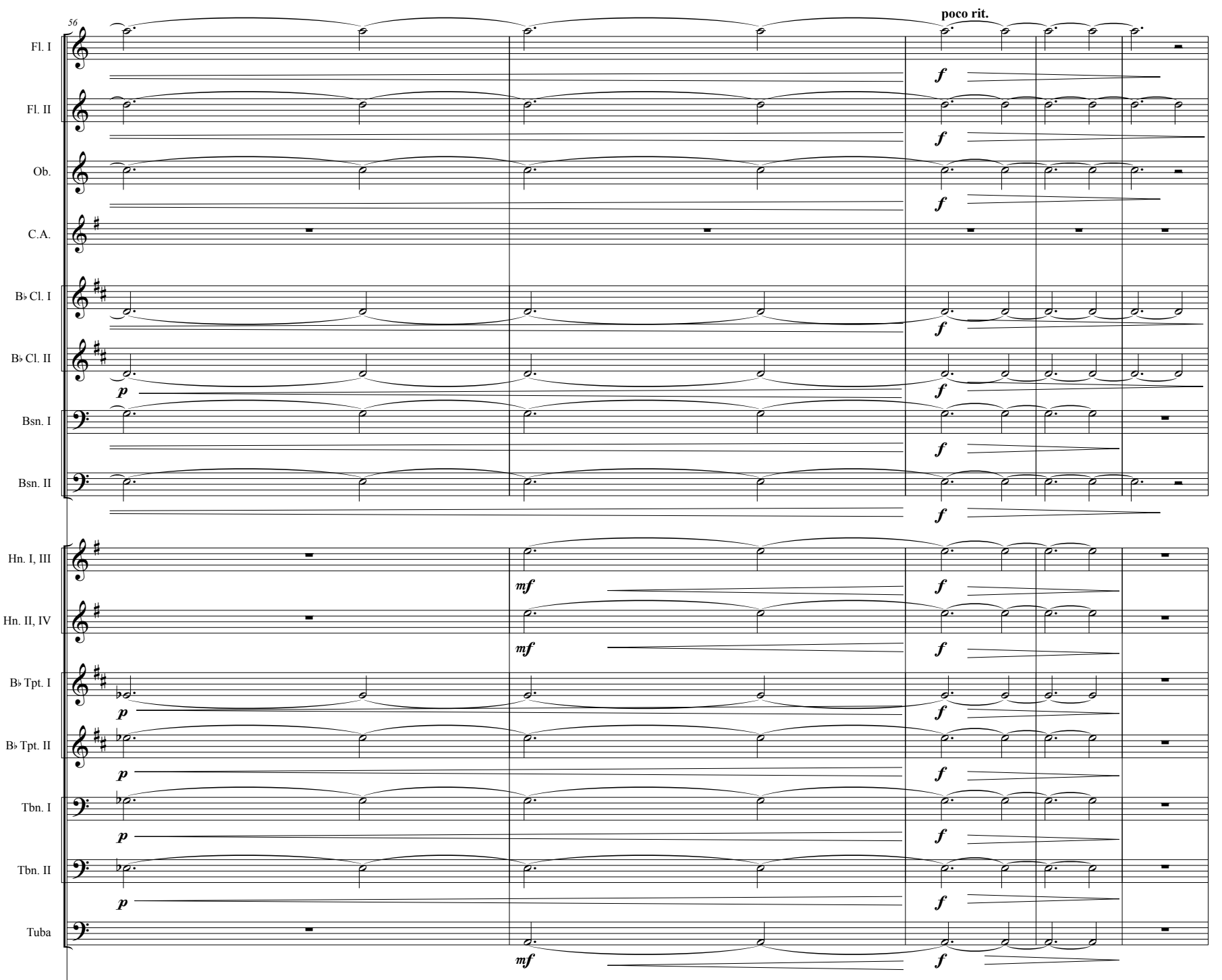

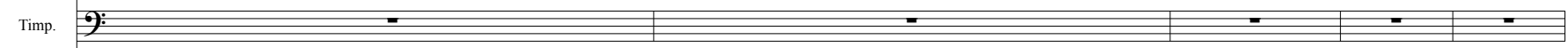
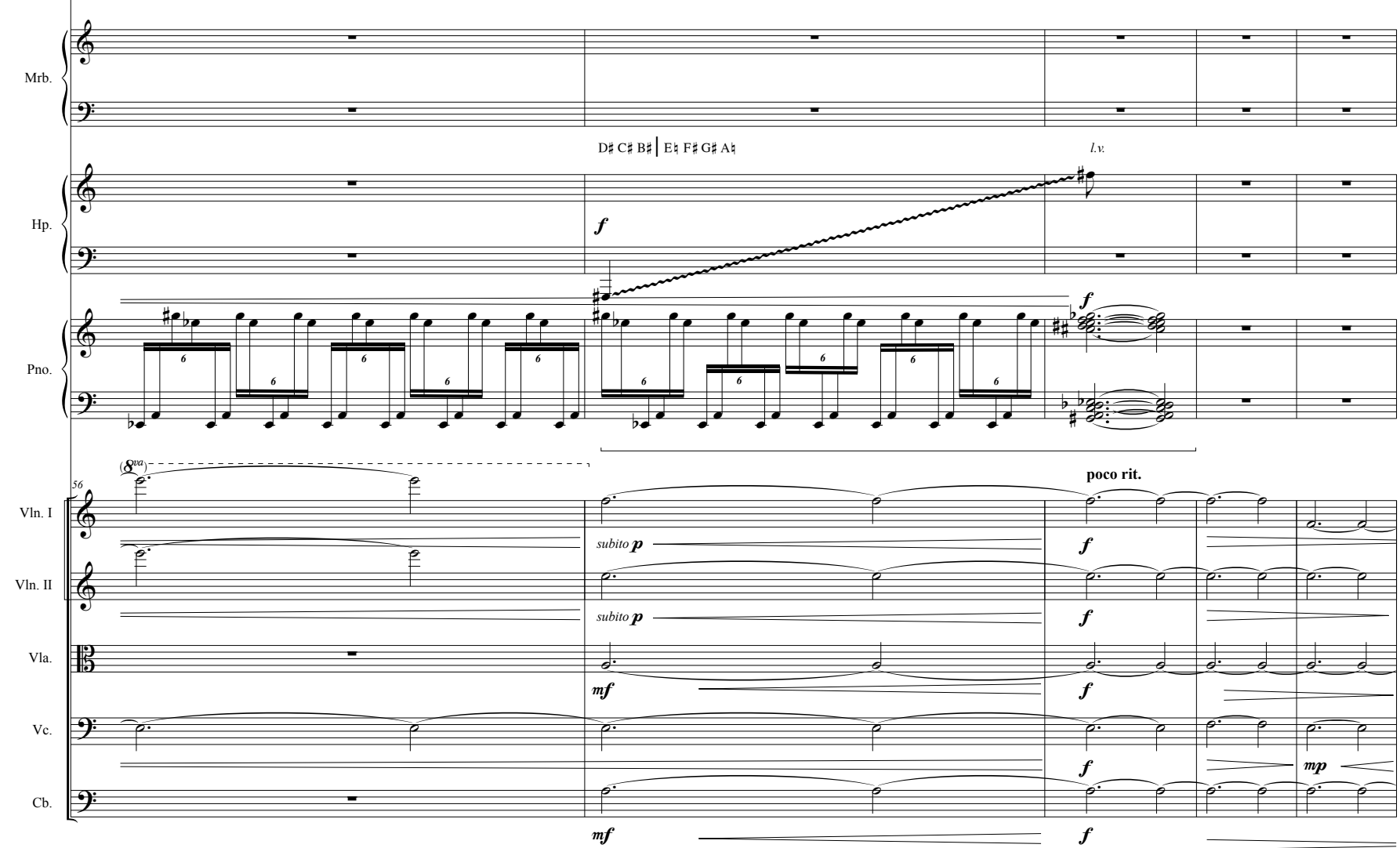

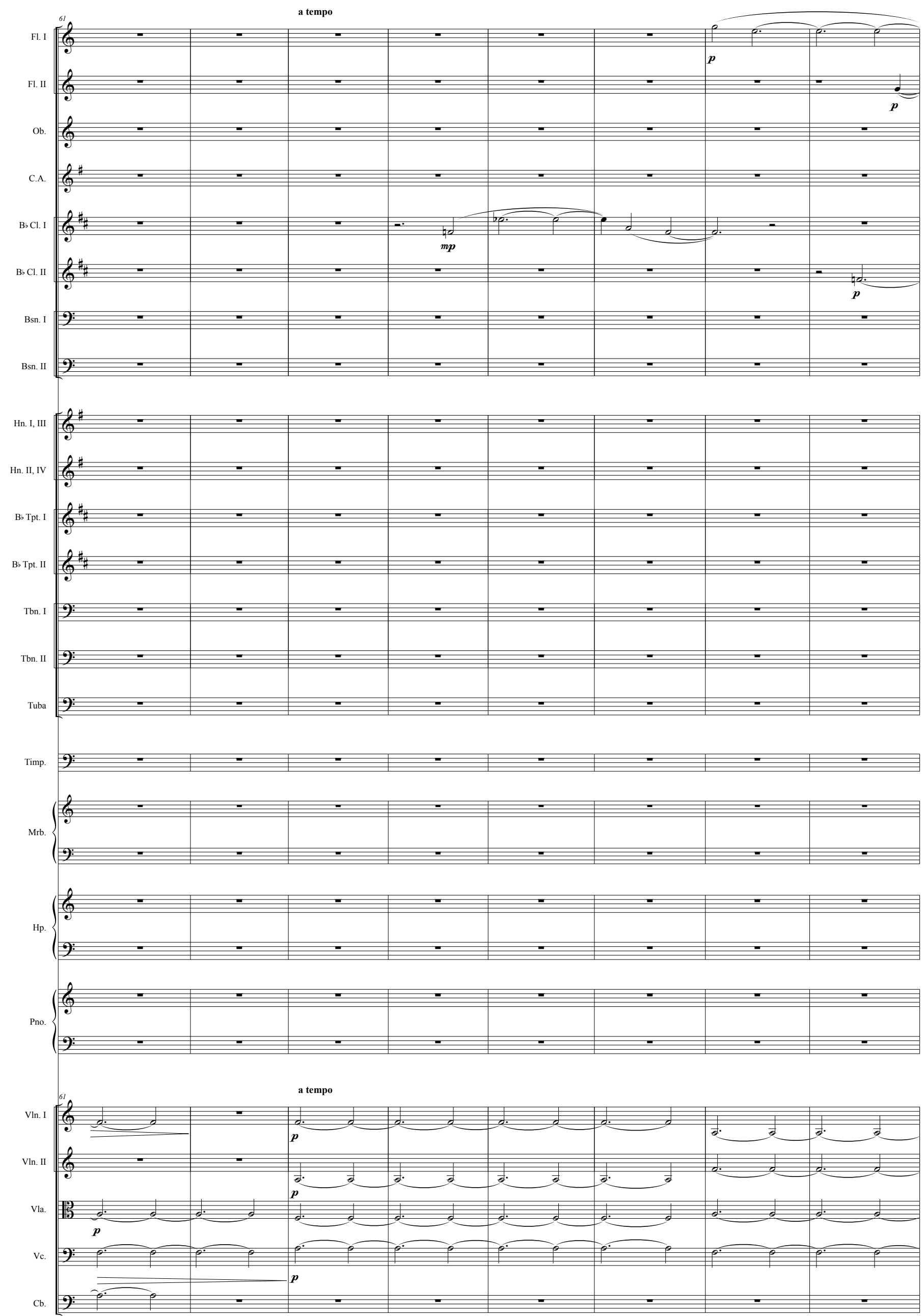

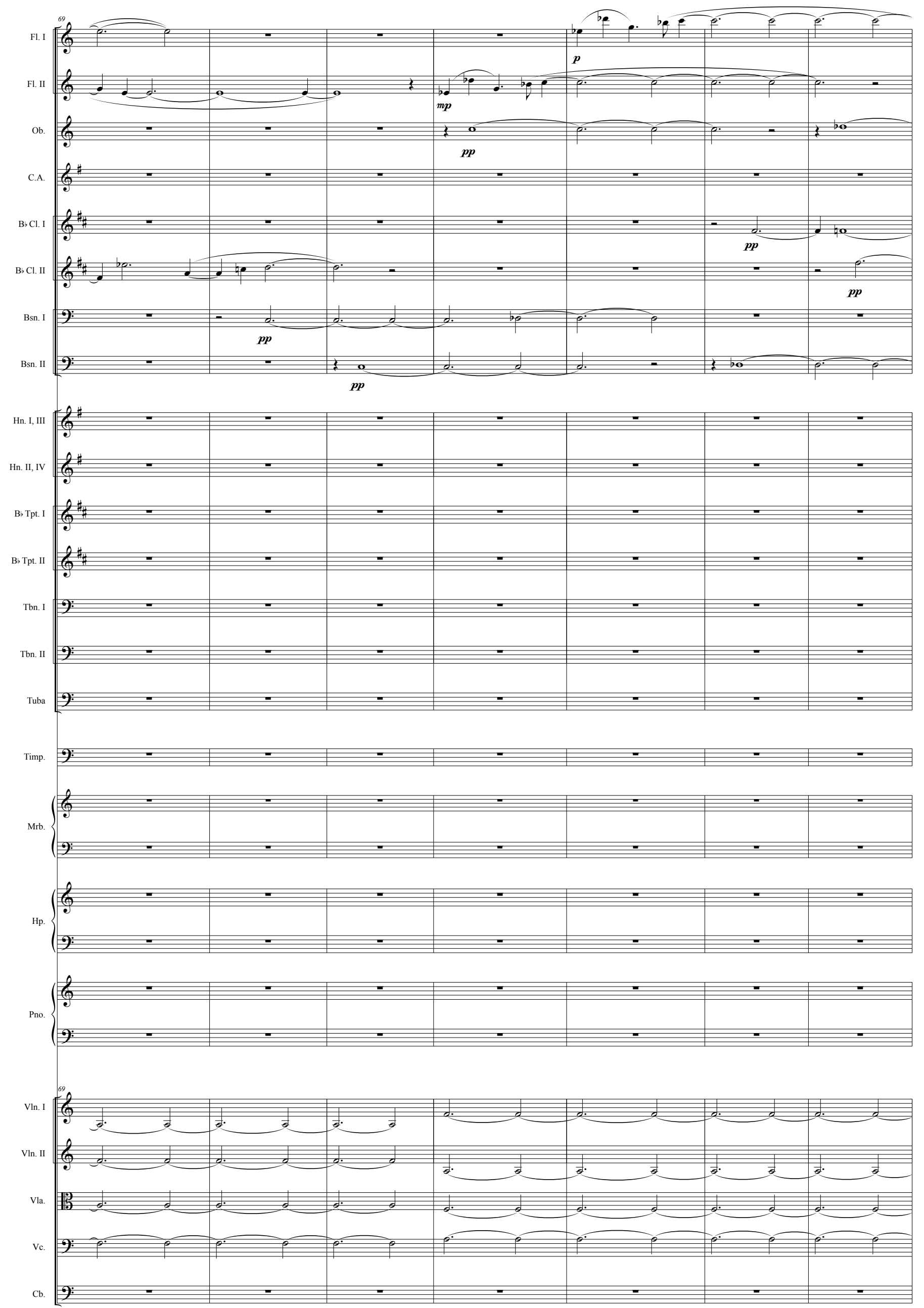

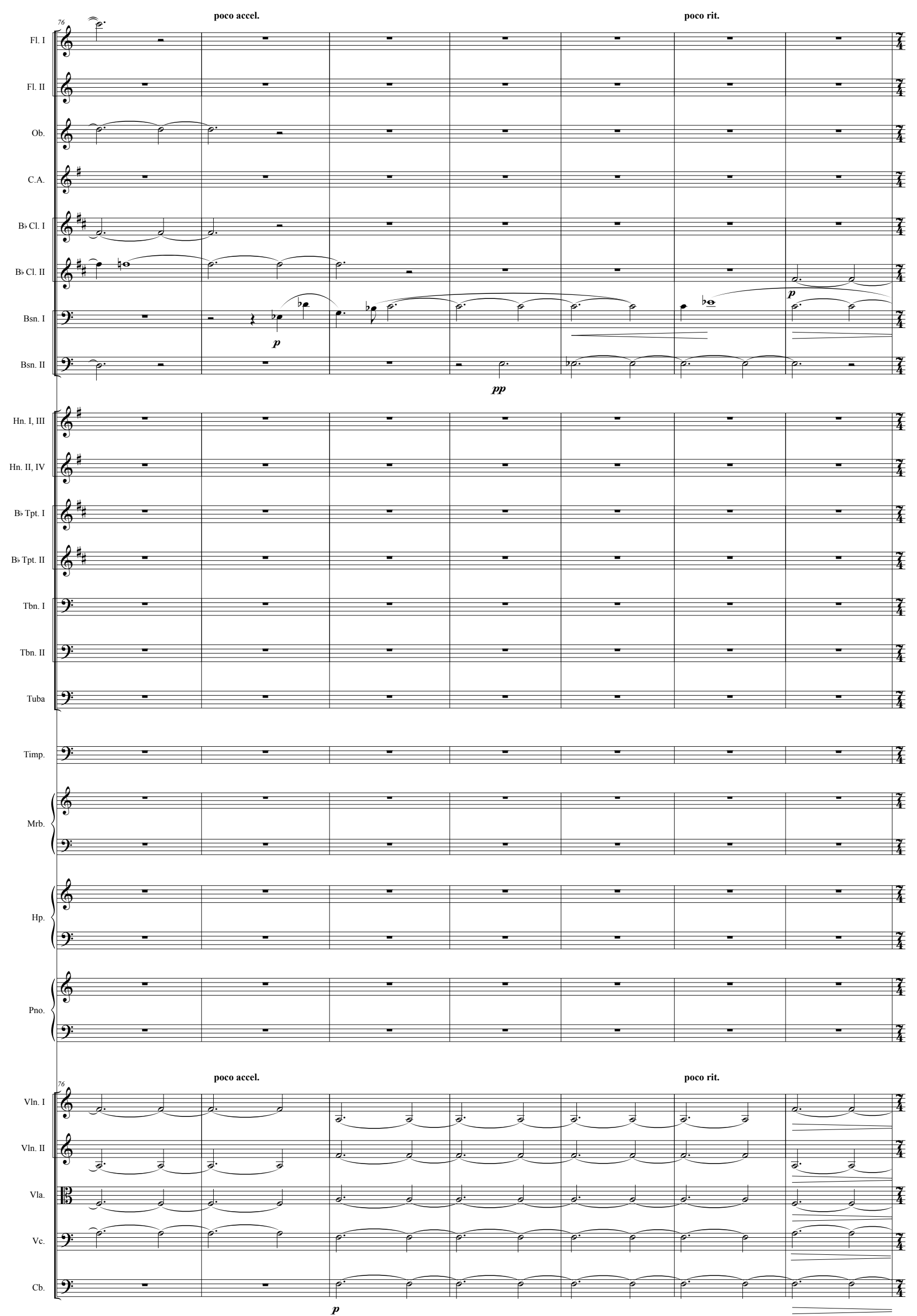

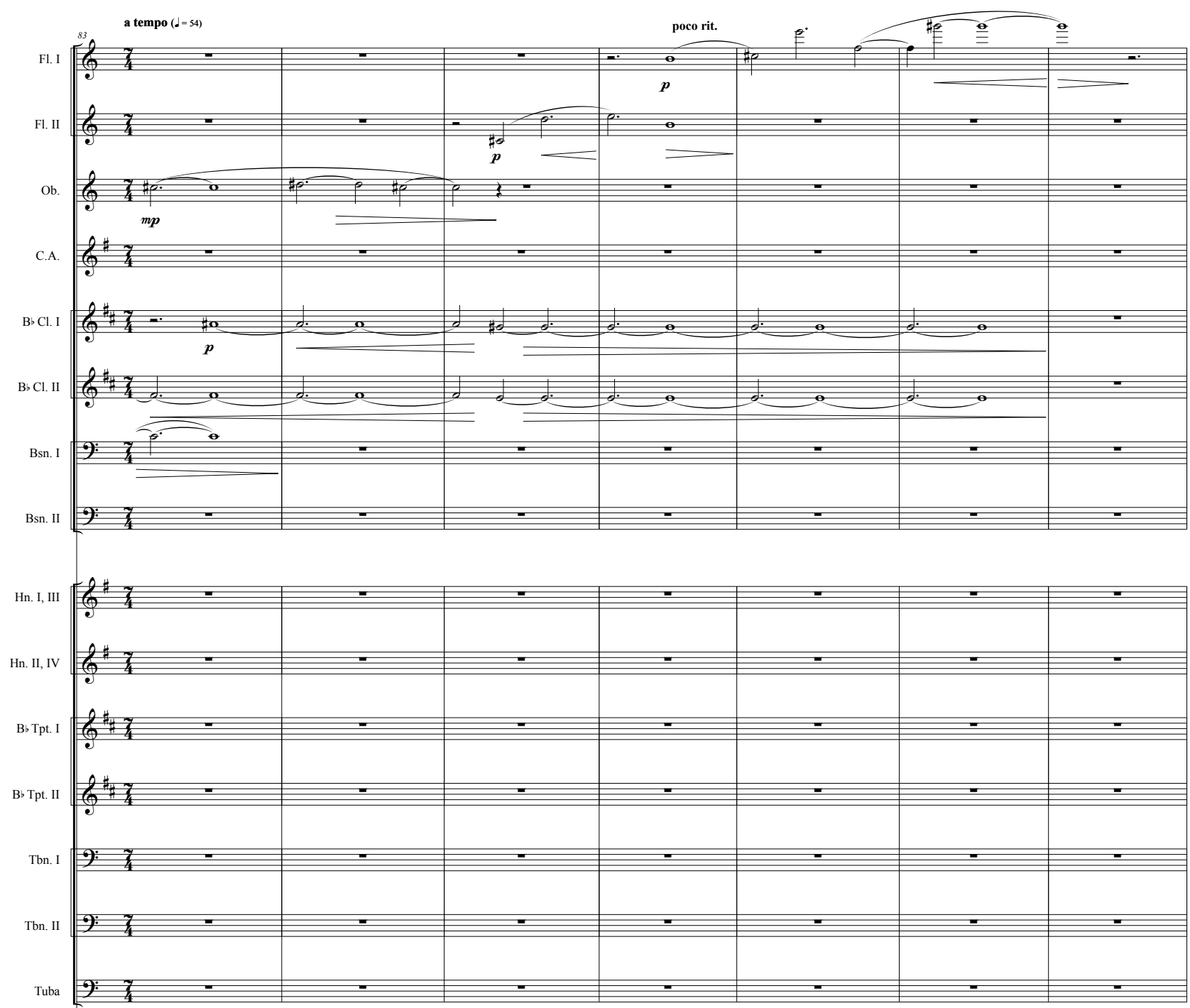

Timp.
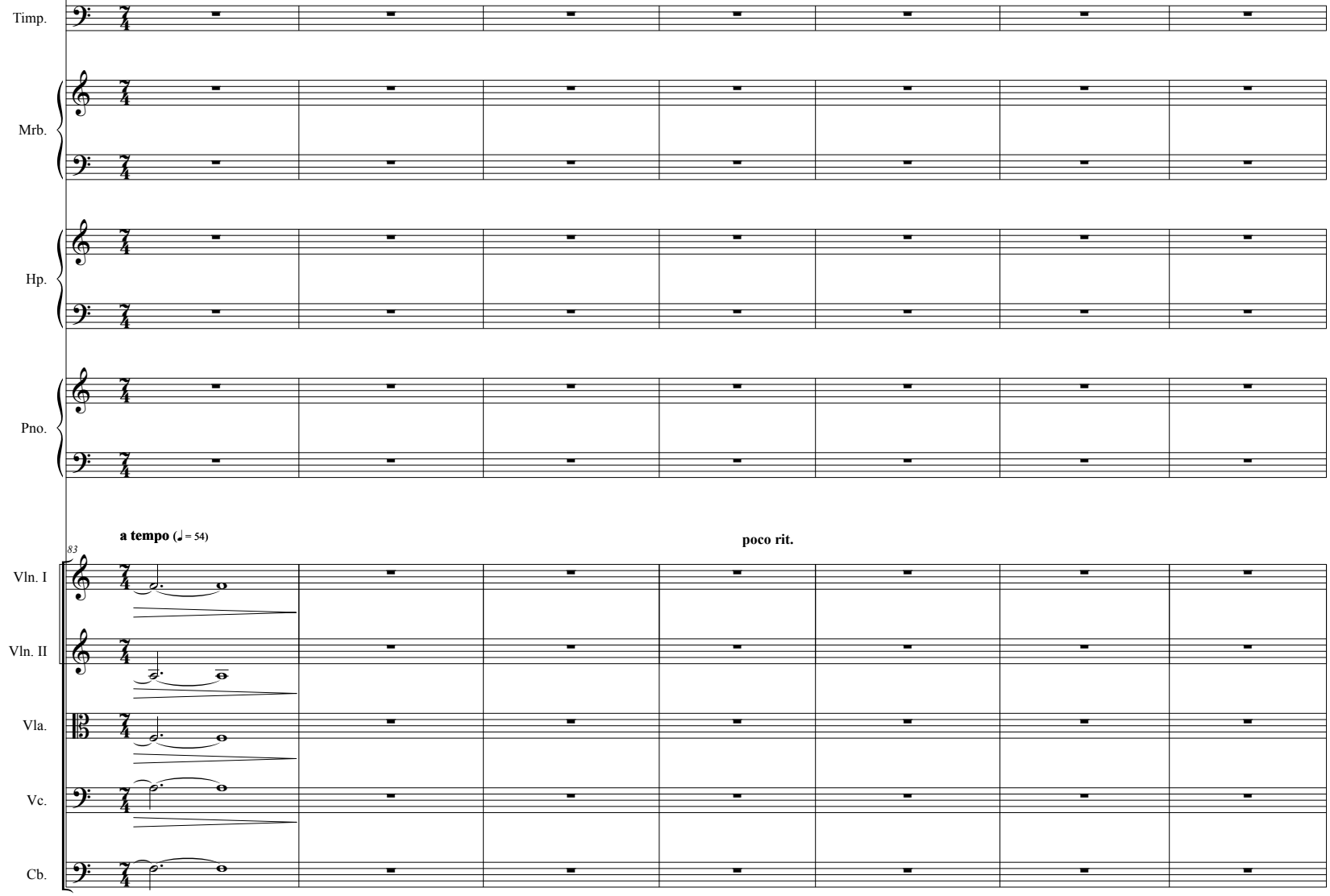


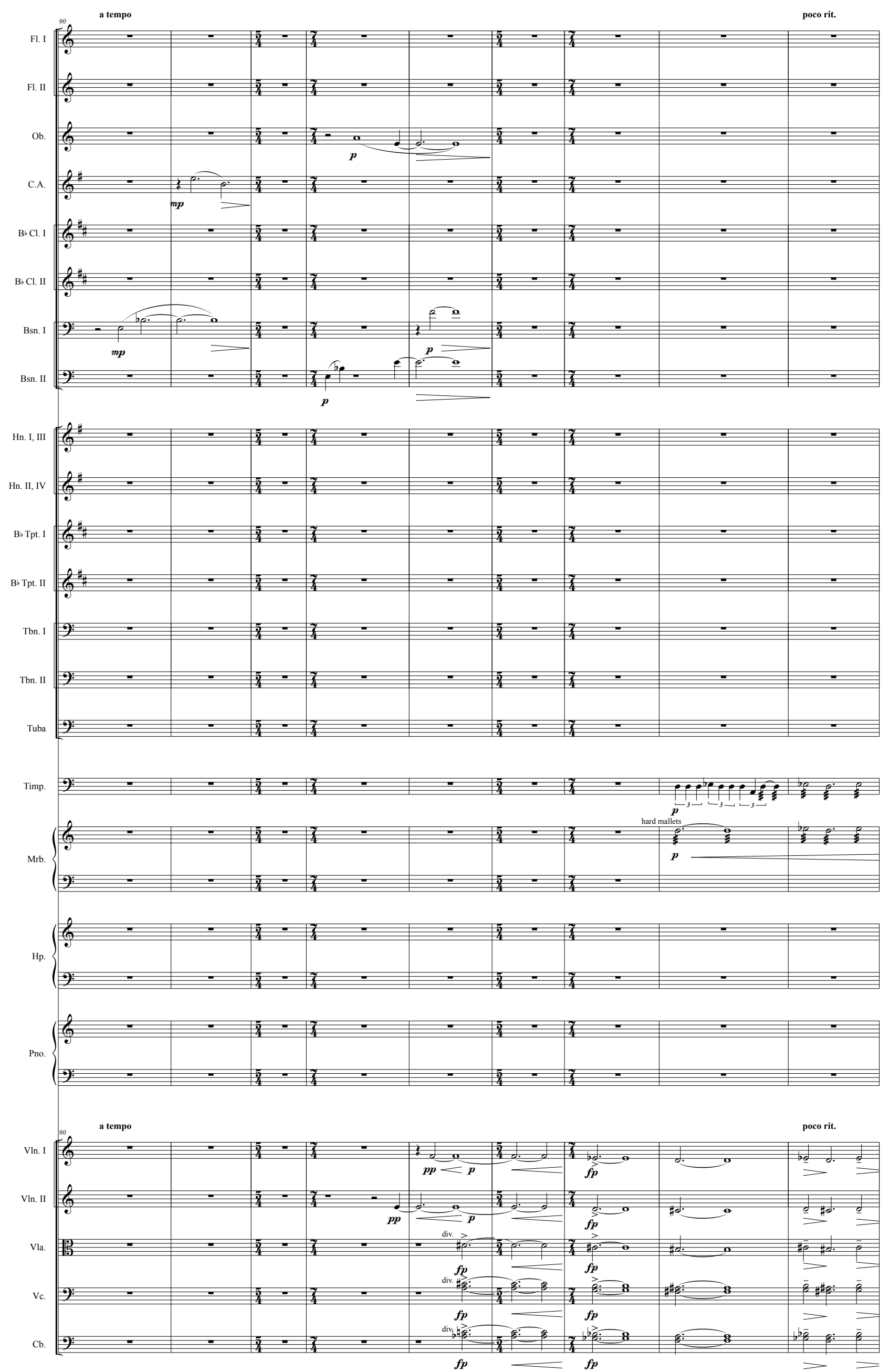



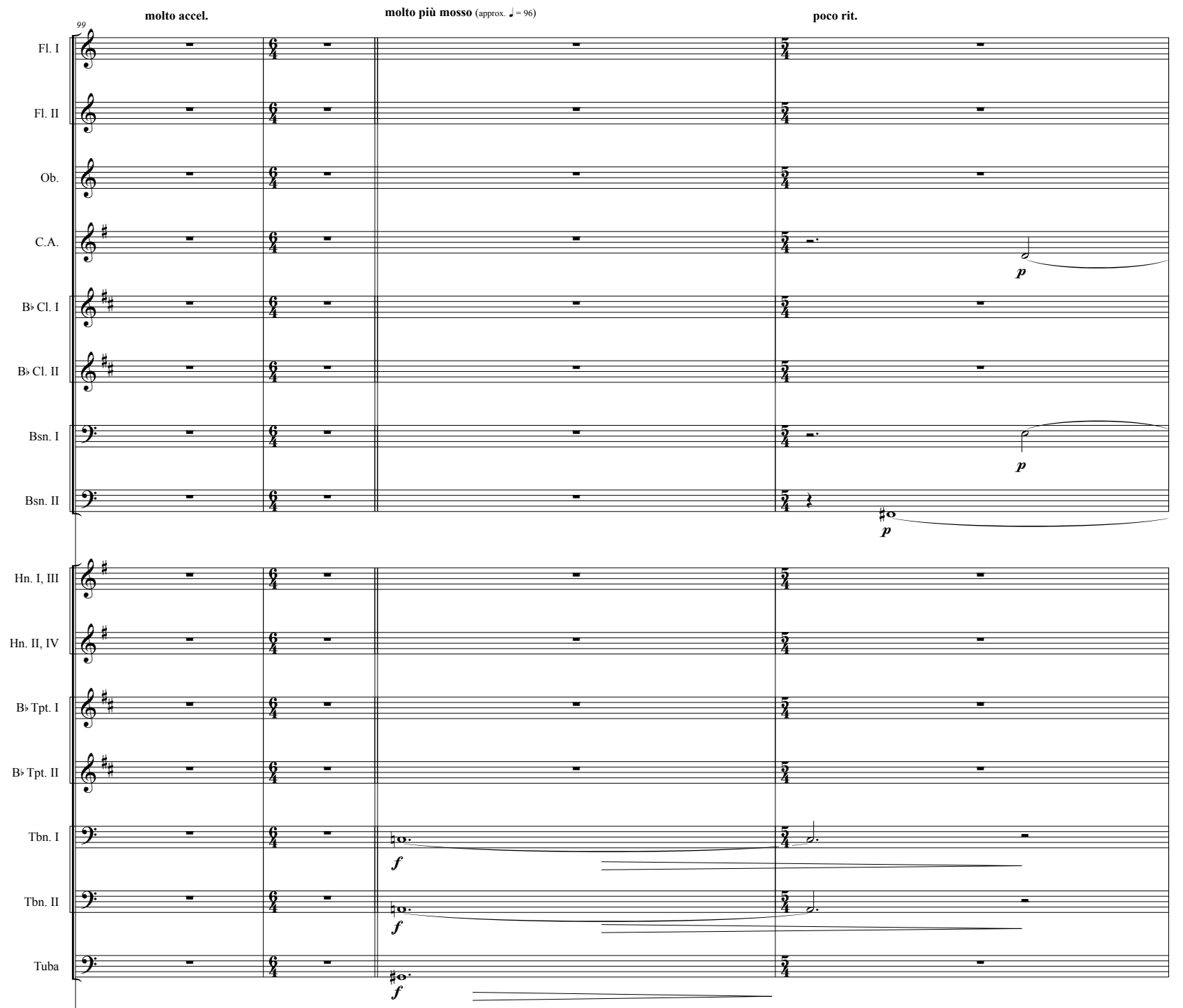

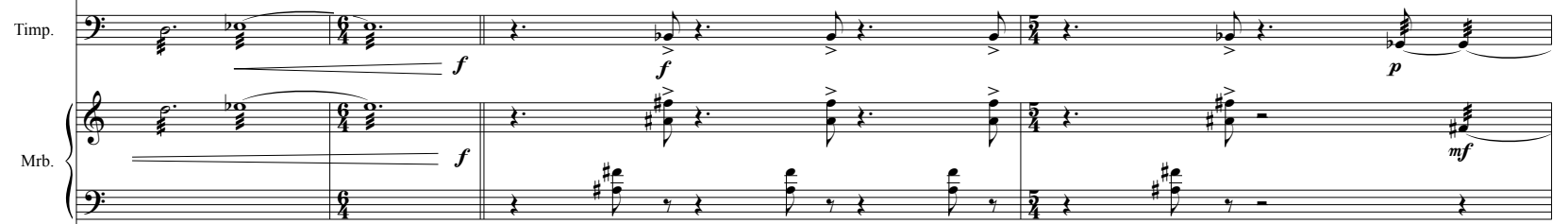

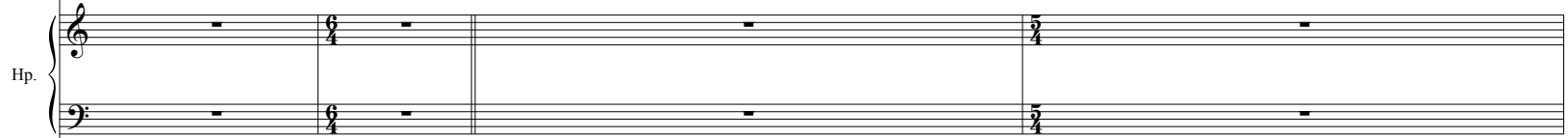

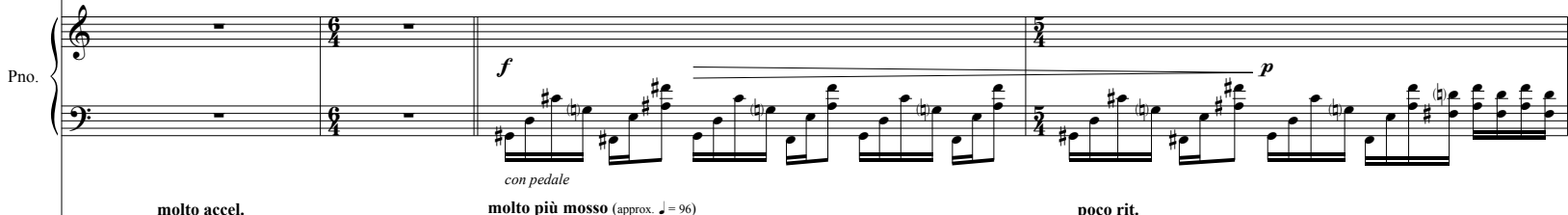

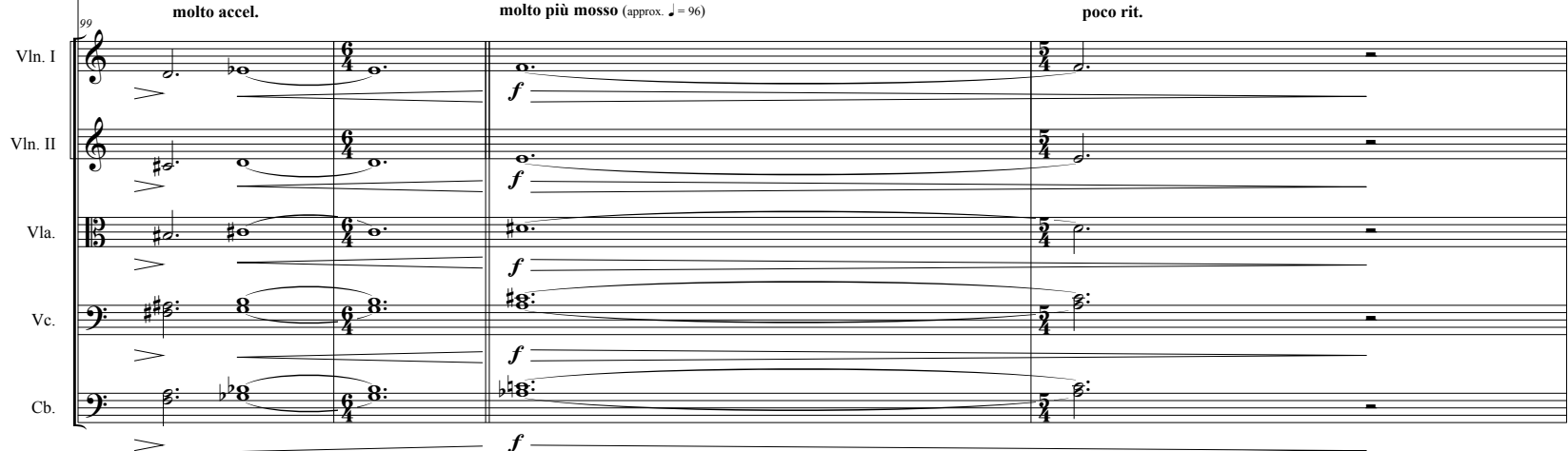




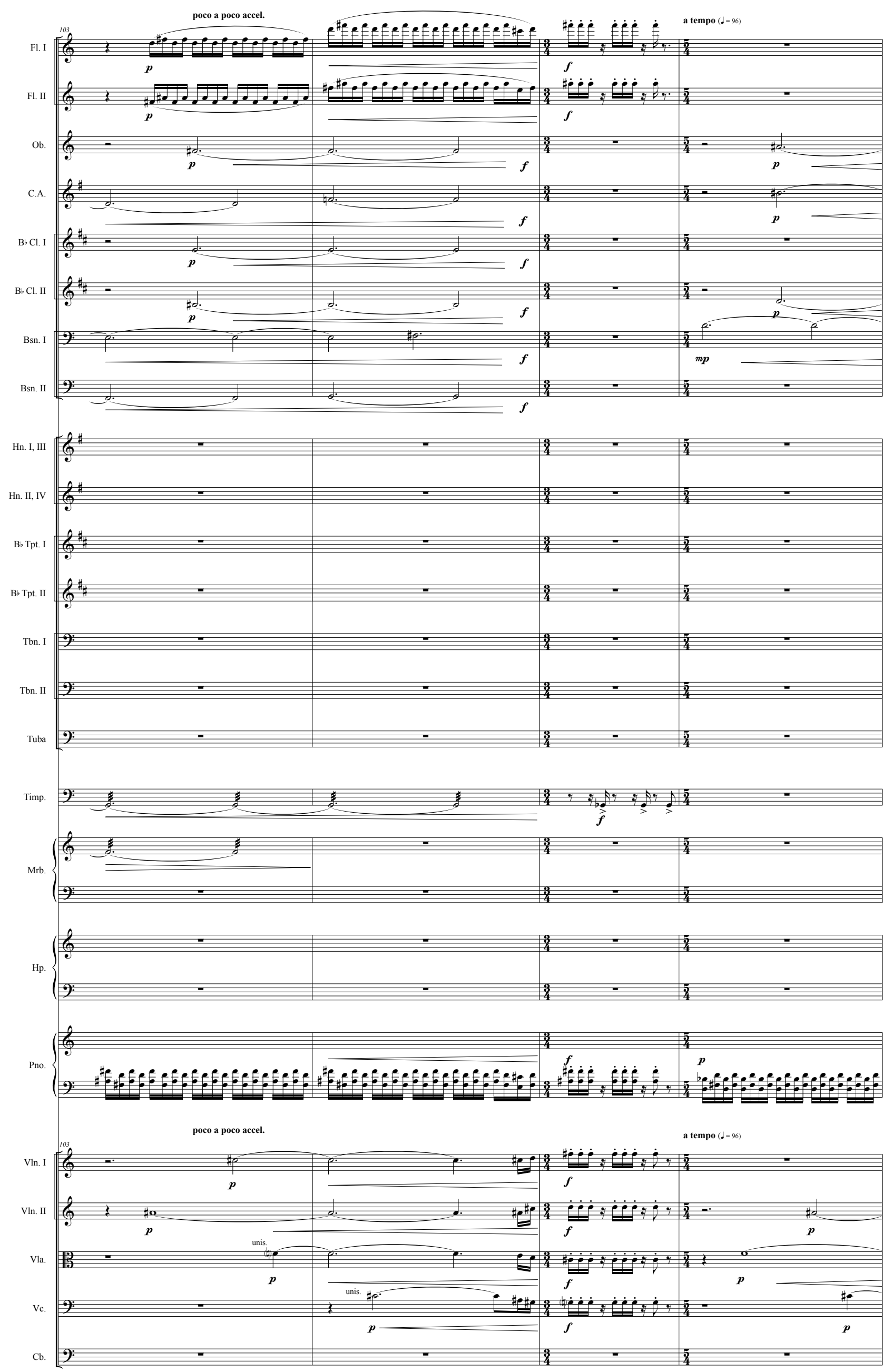



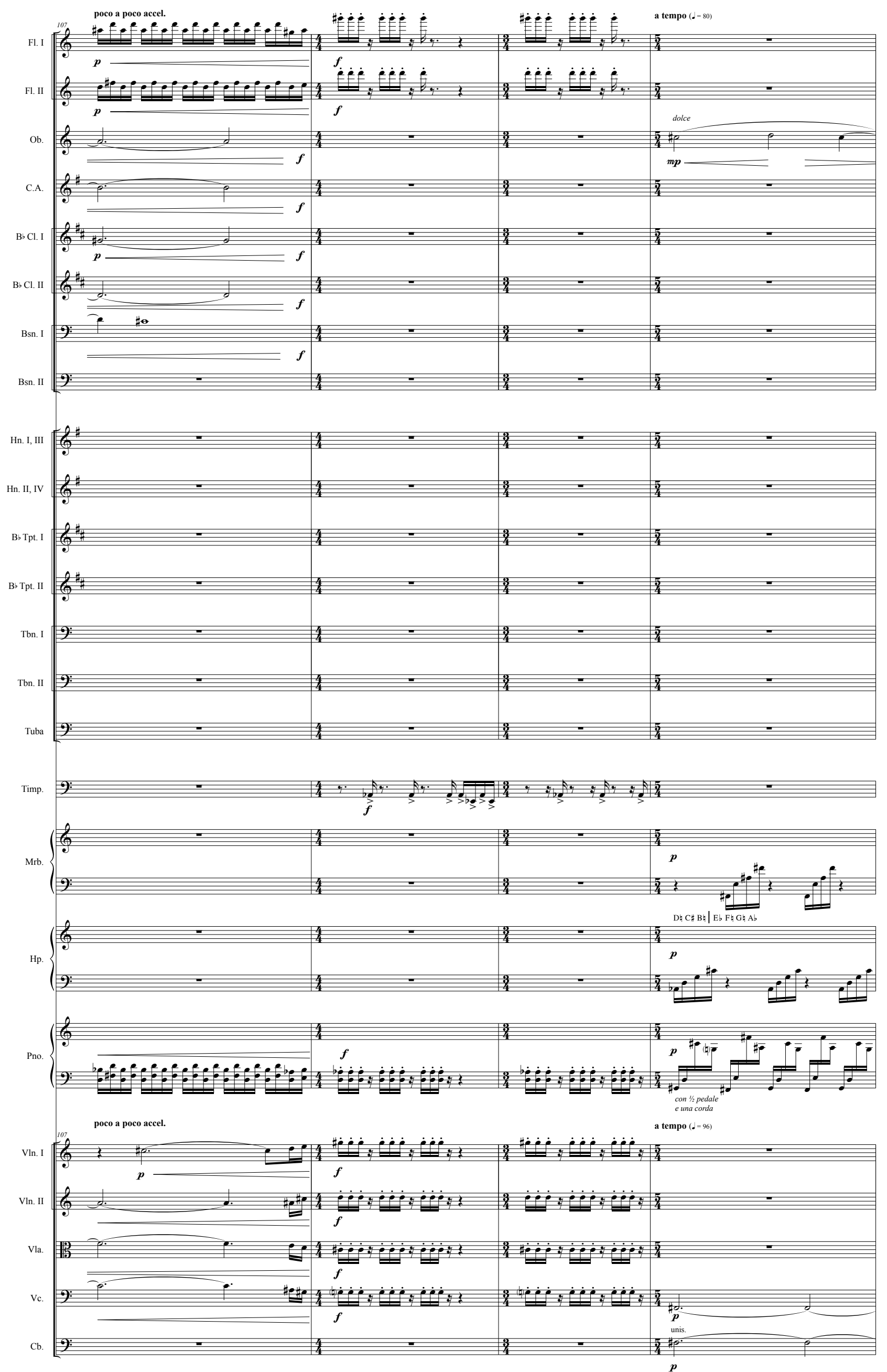


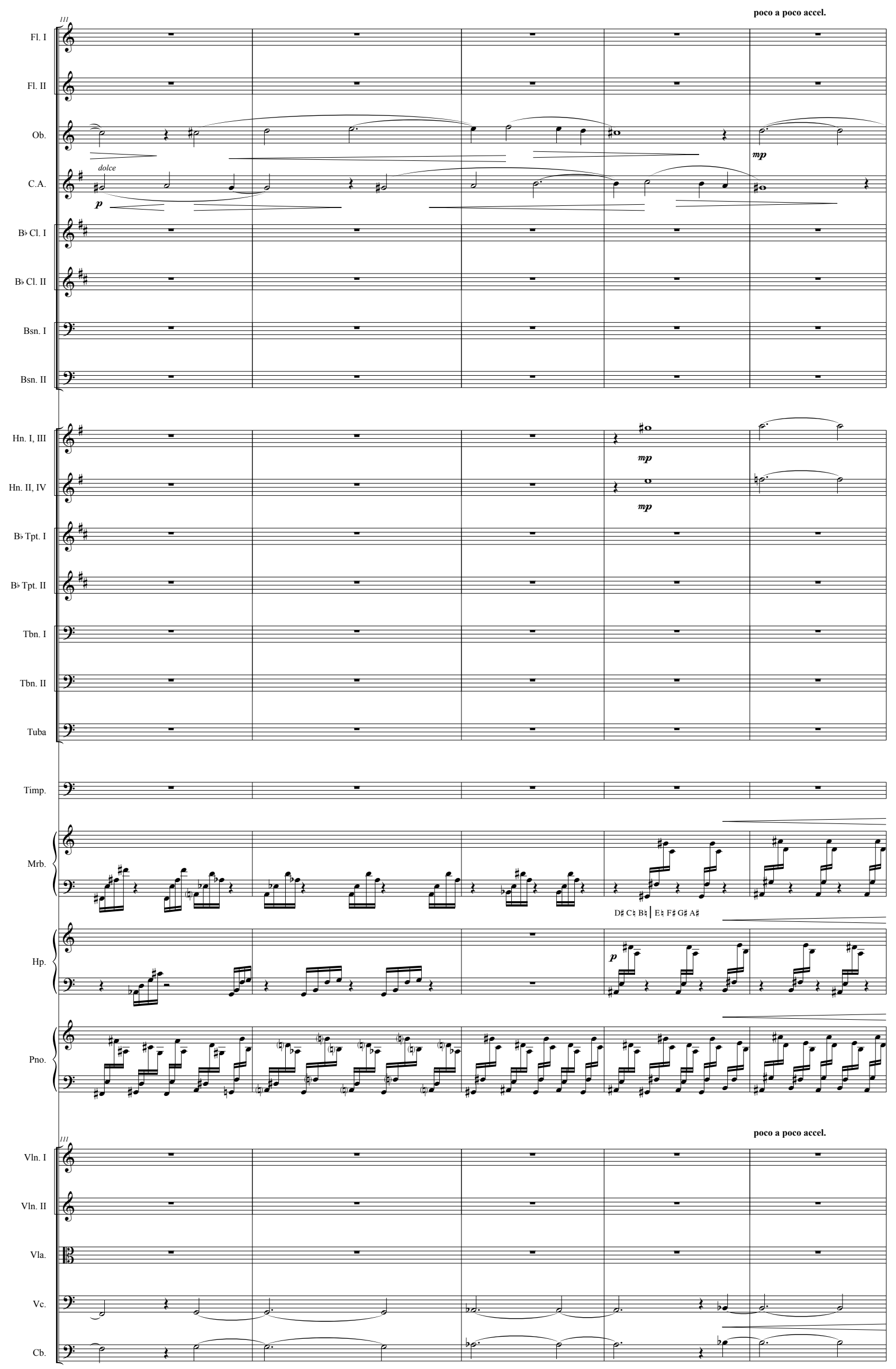




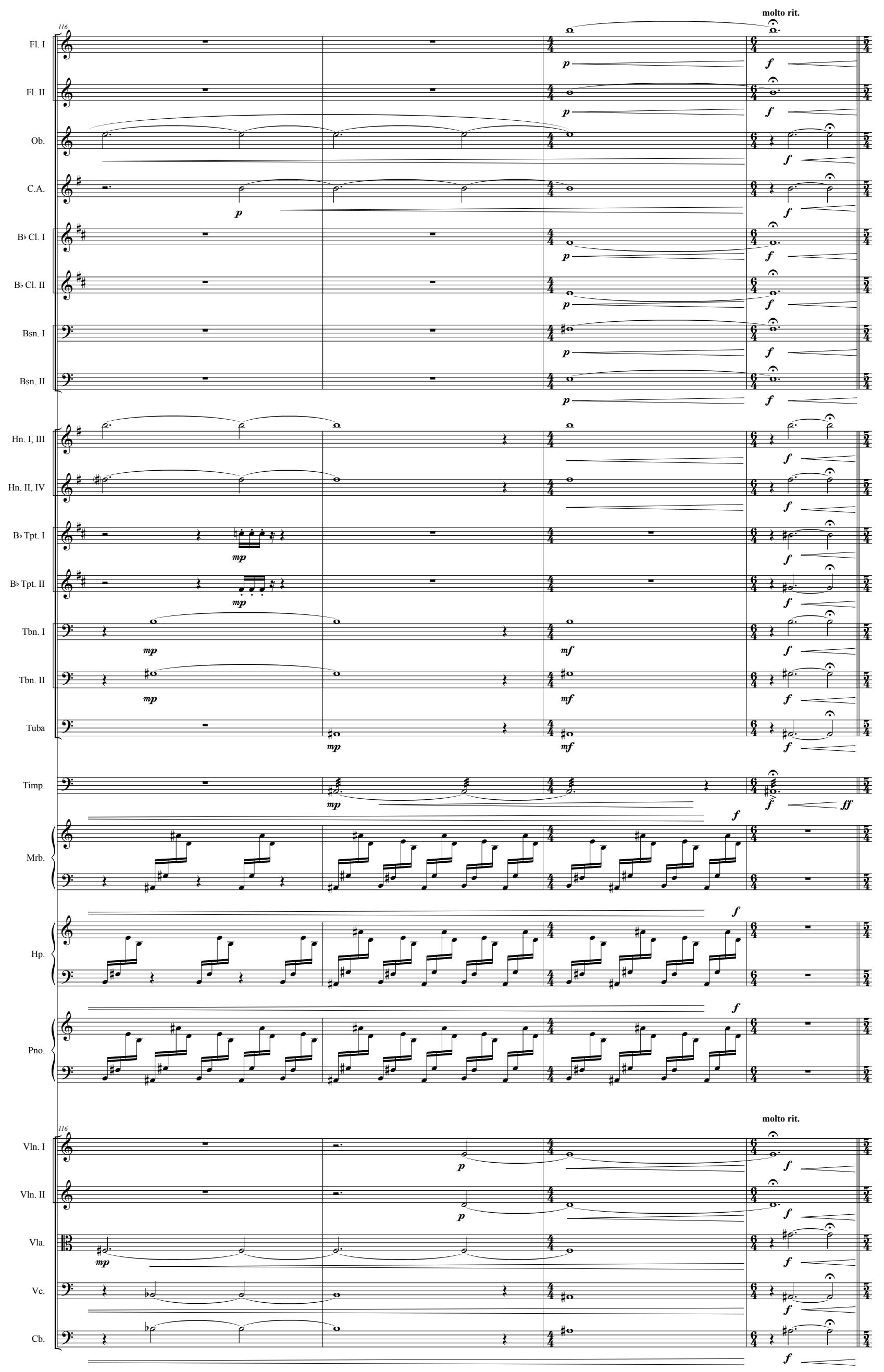




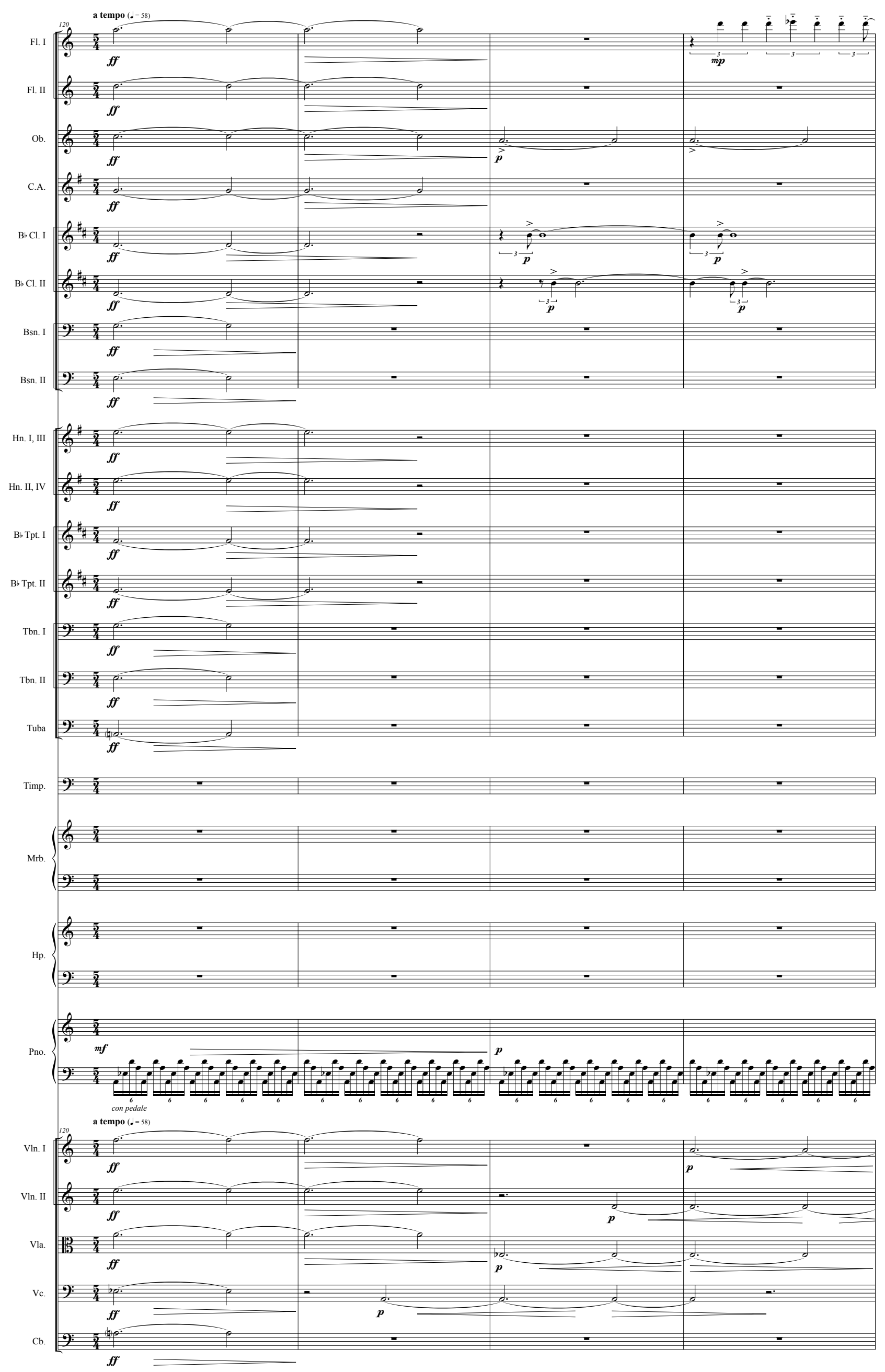



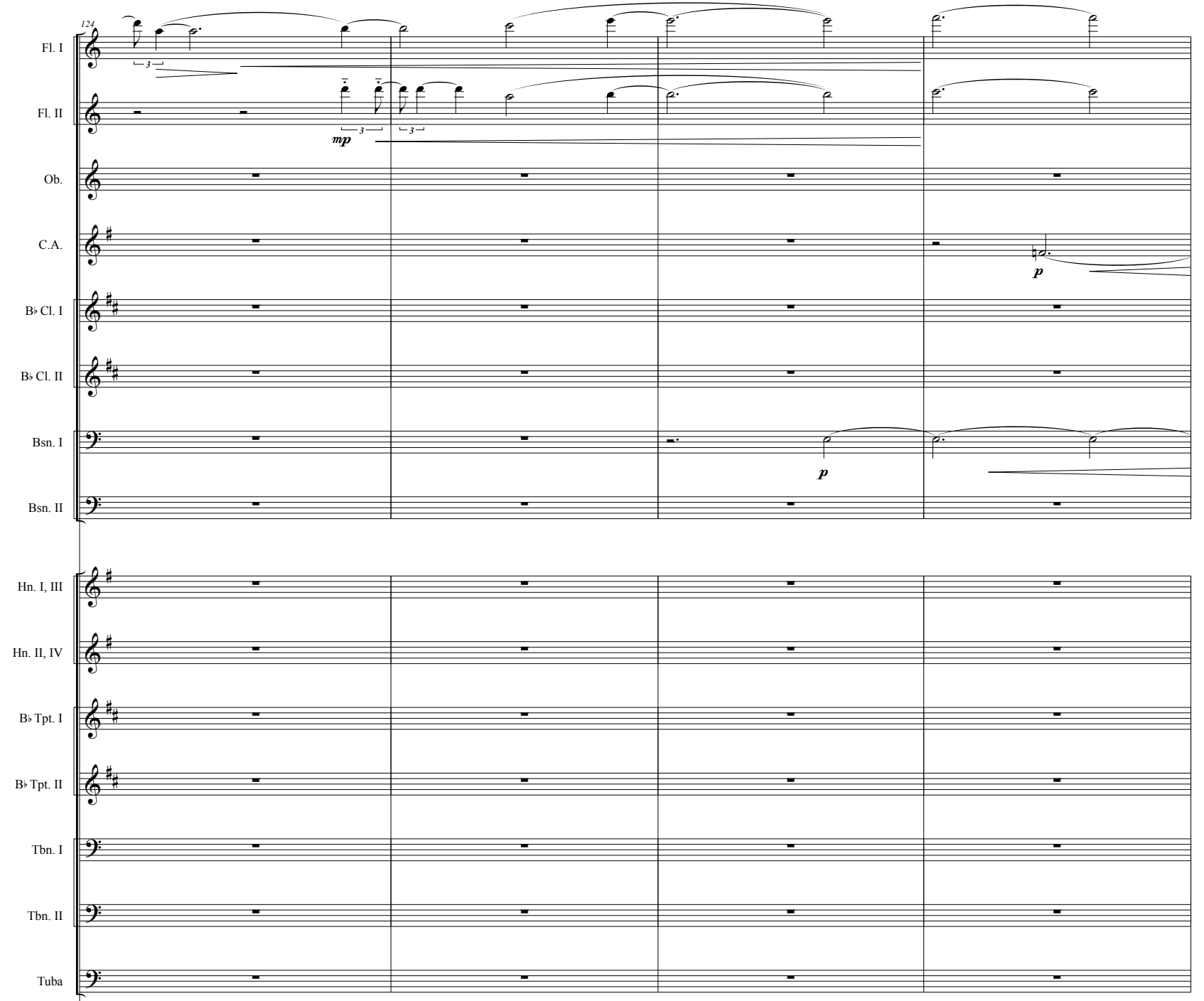

Timp.

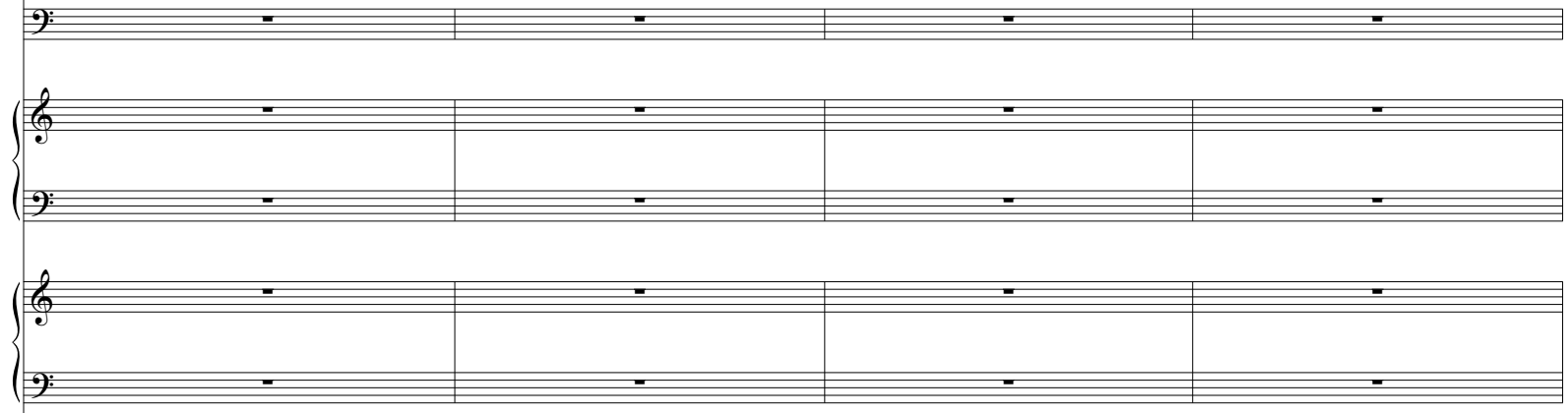

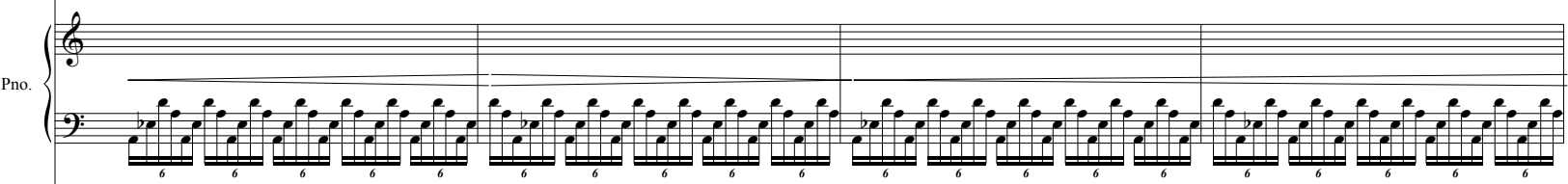

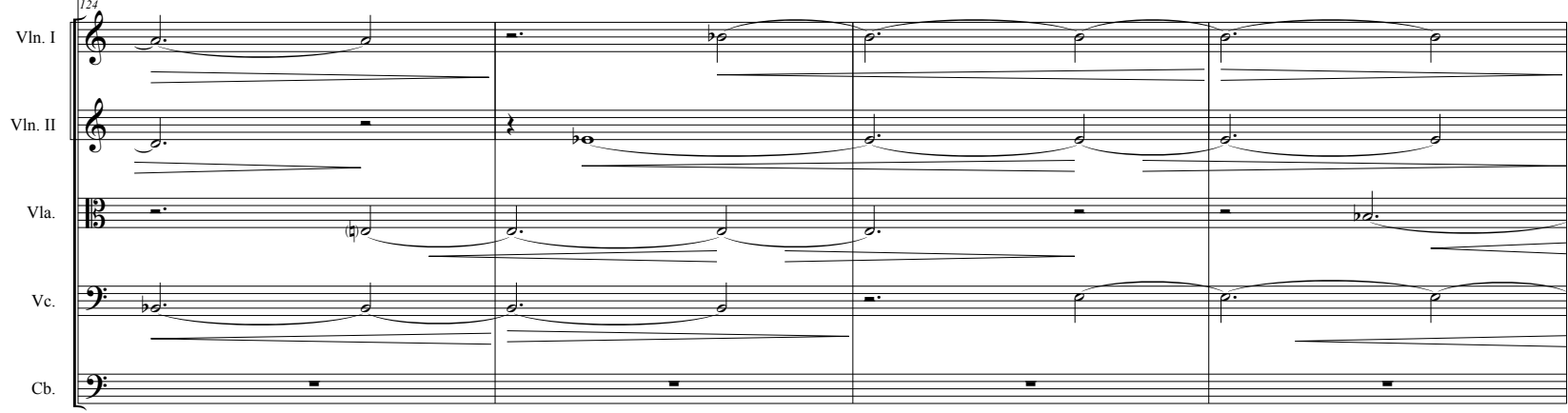



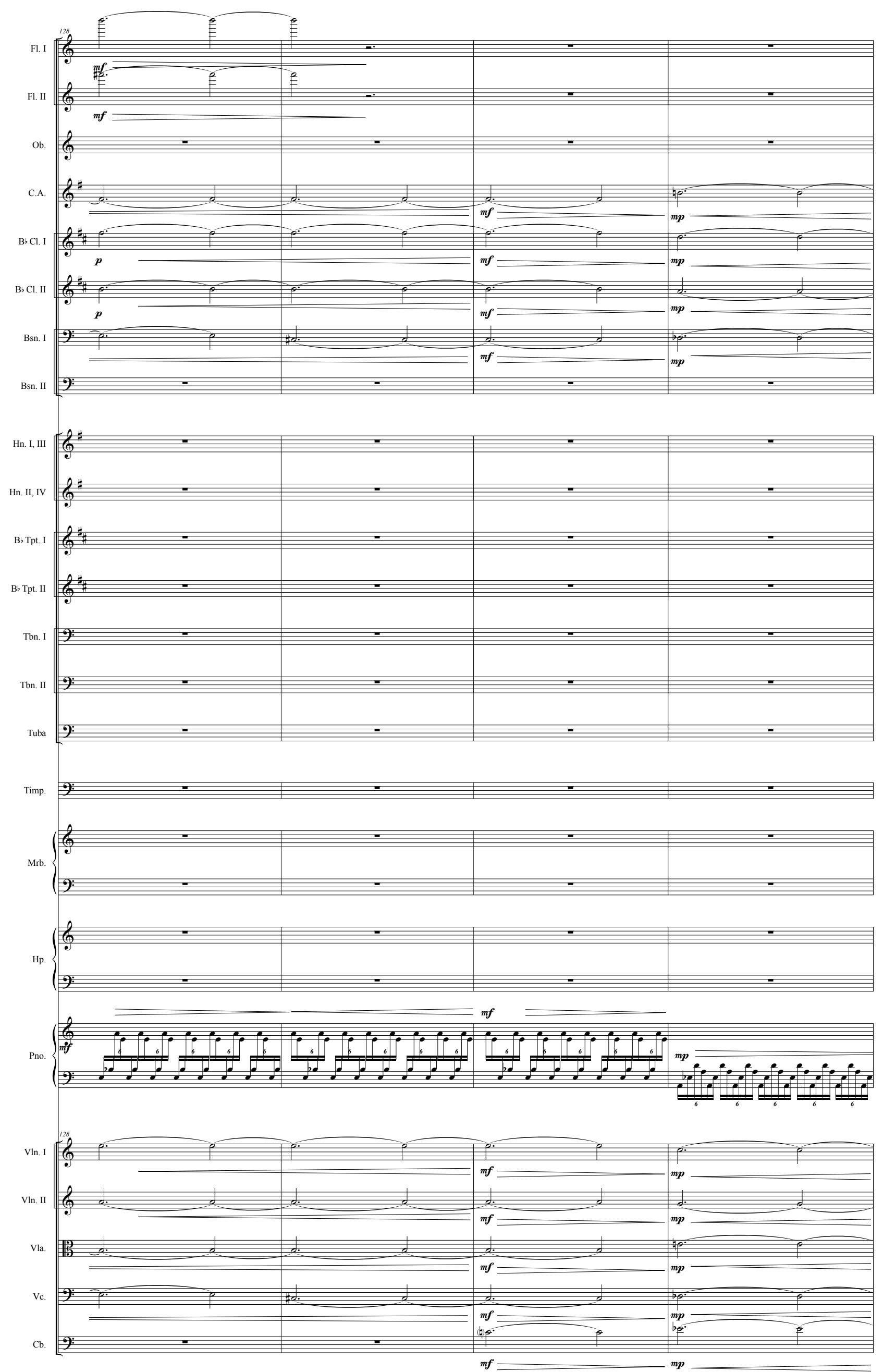


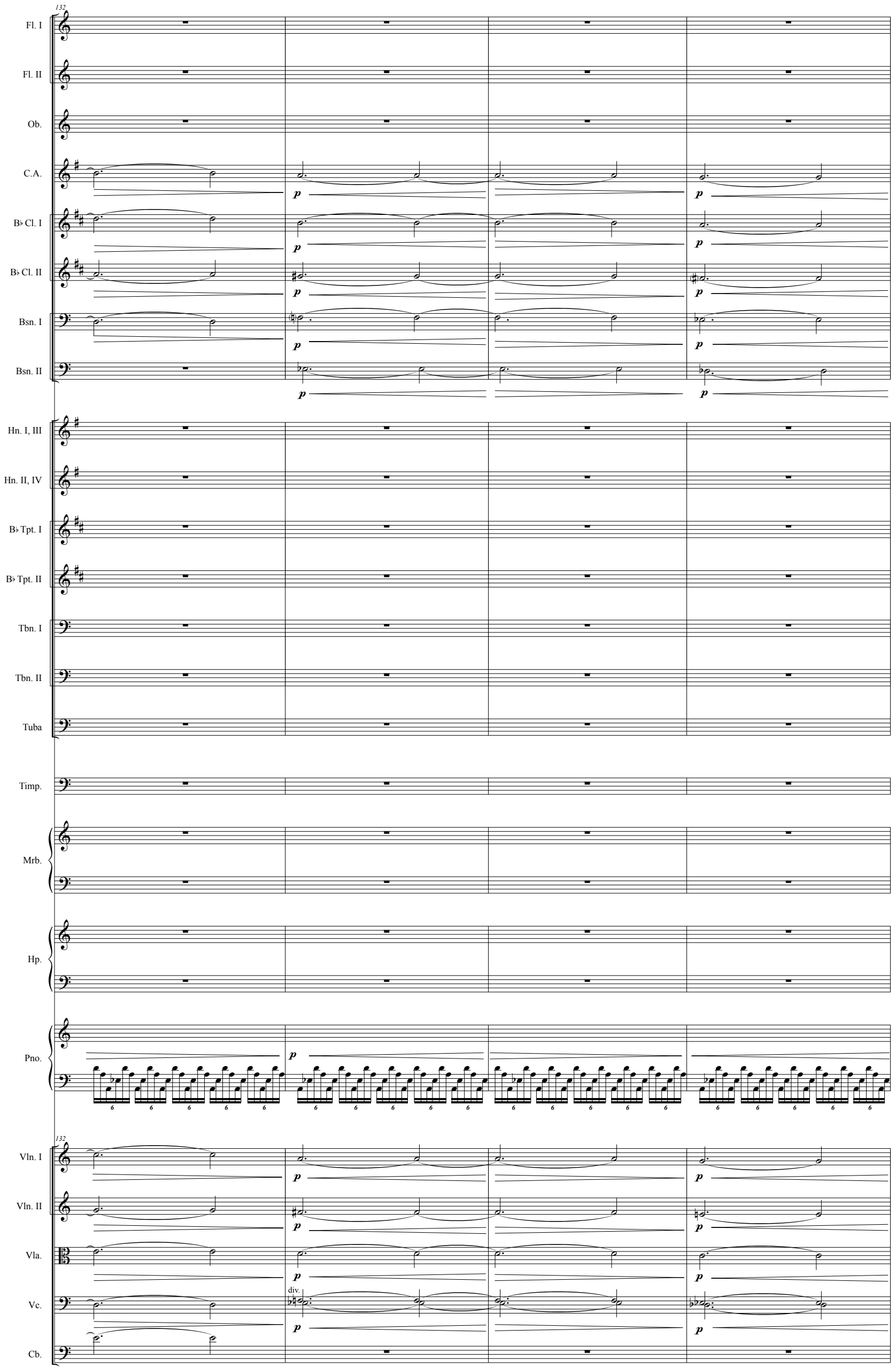



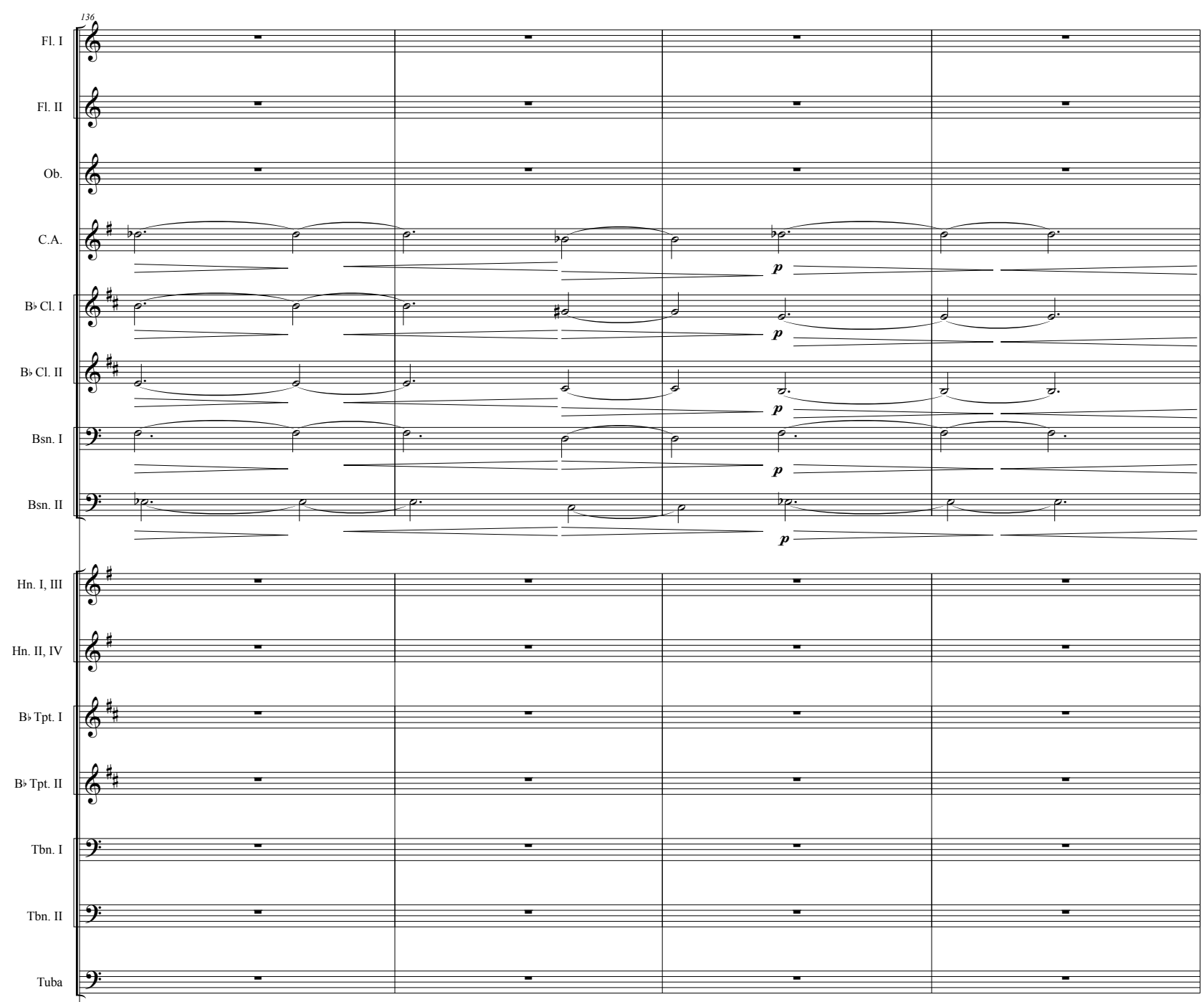

Timp.

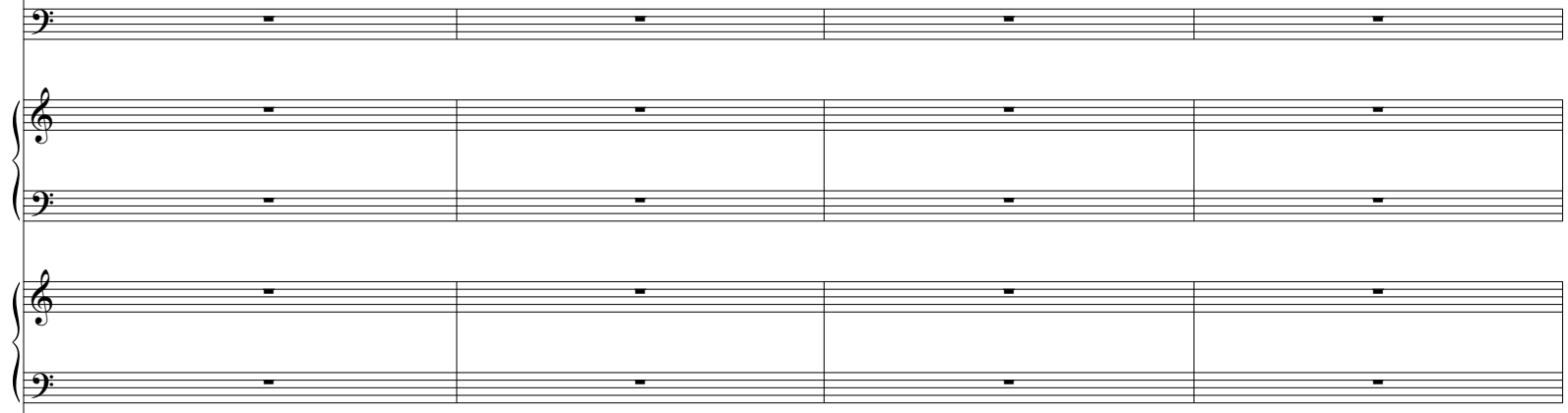

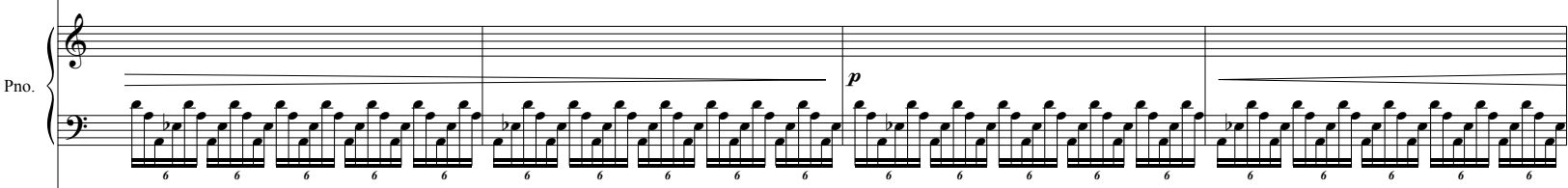

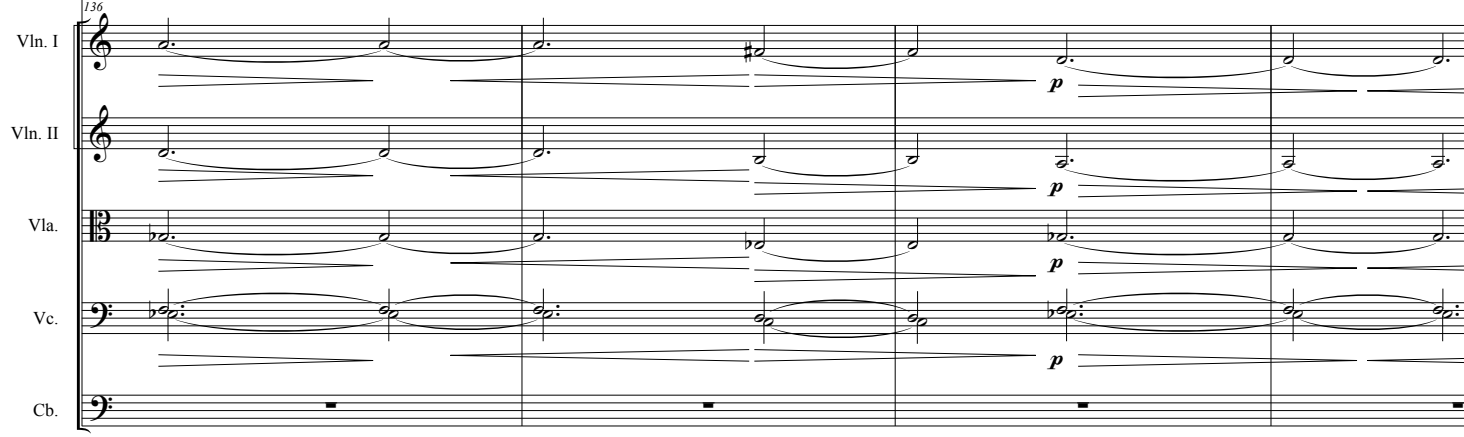



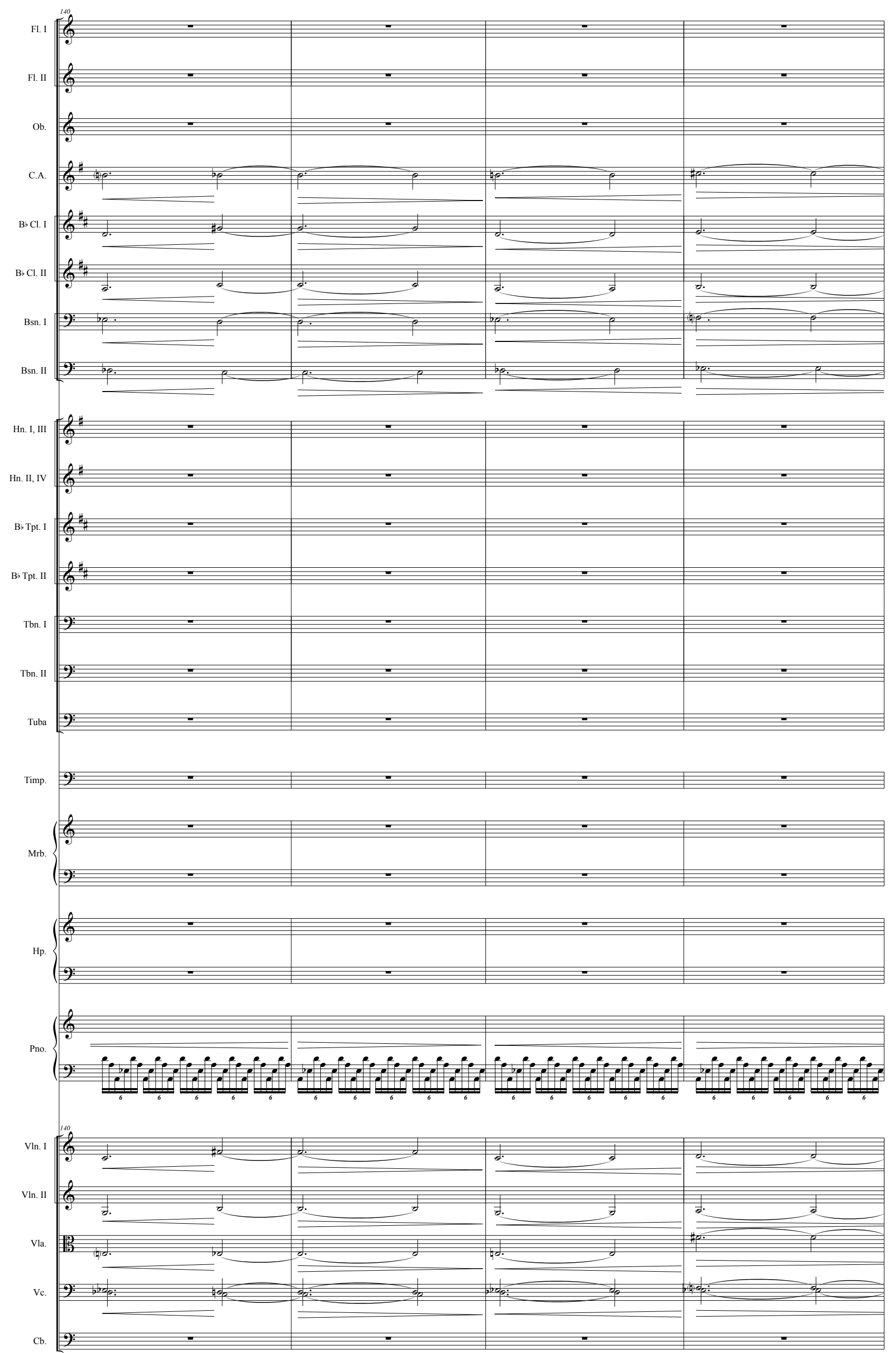

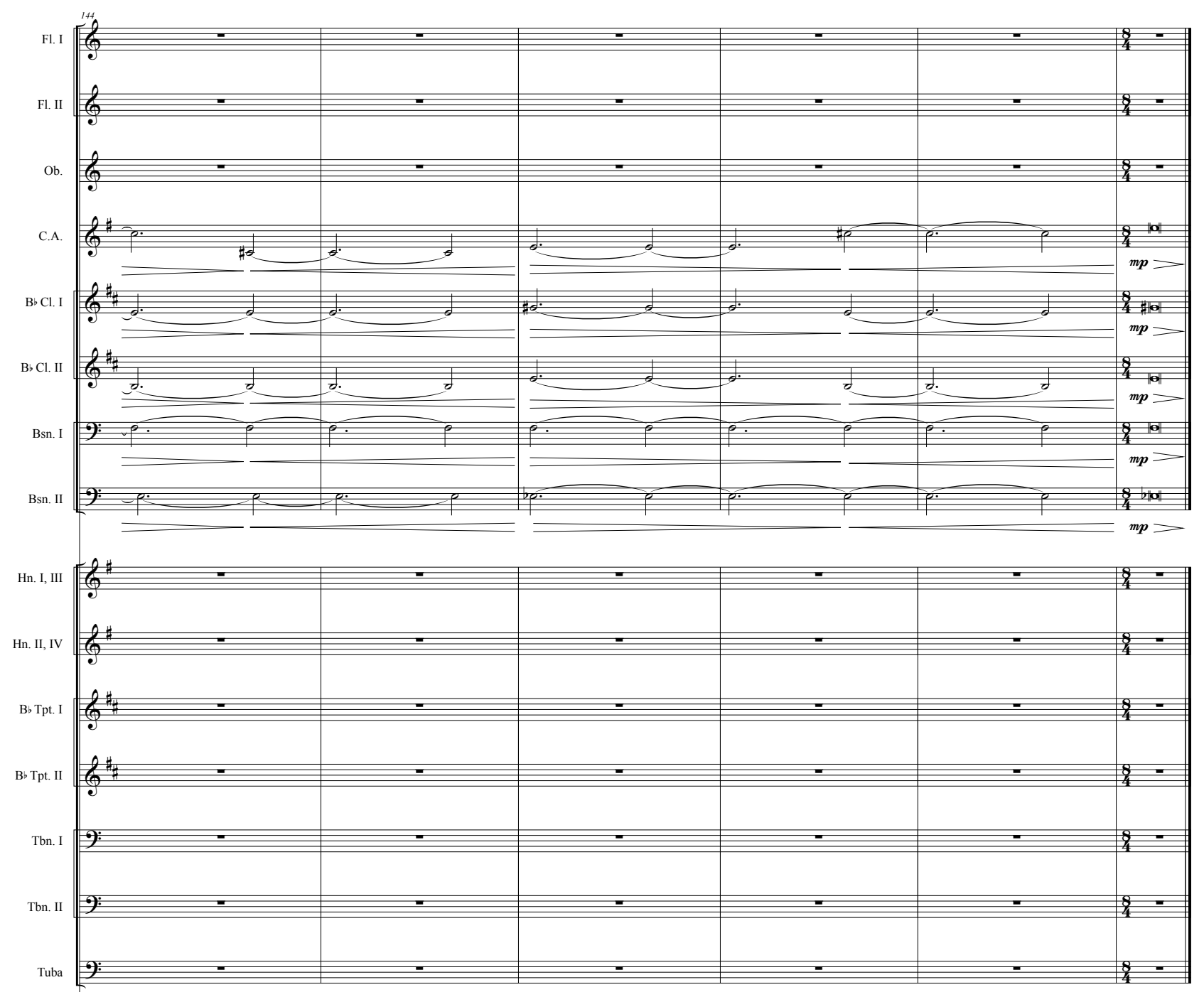

Timp
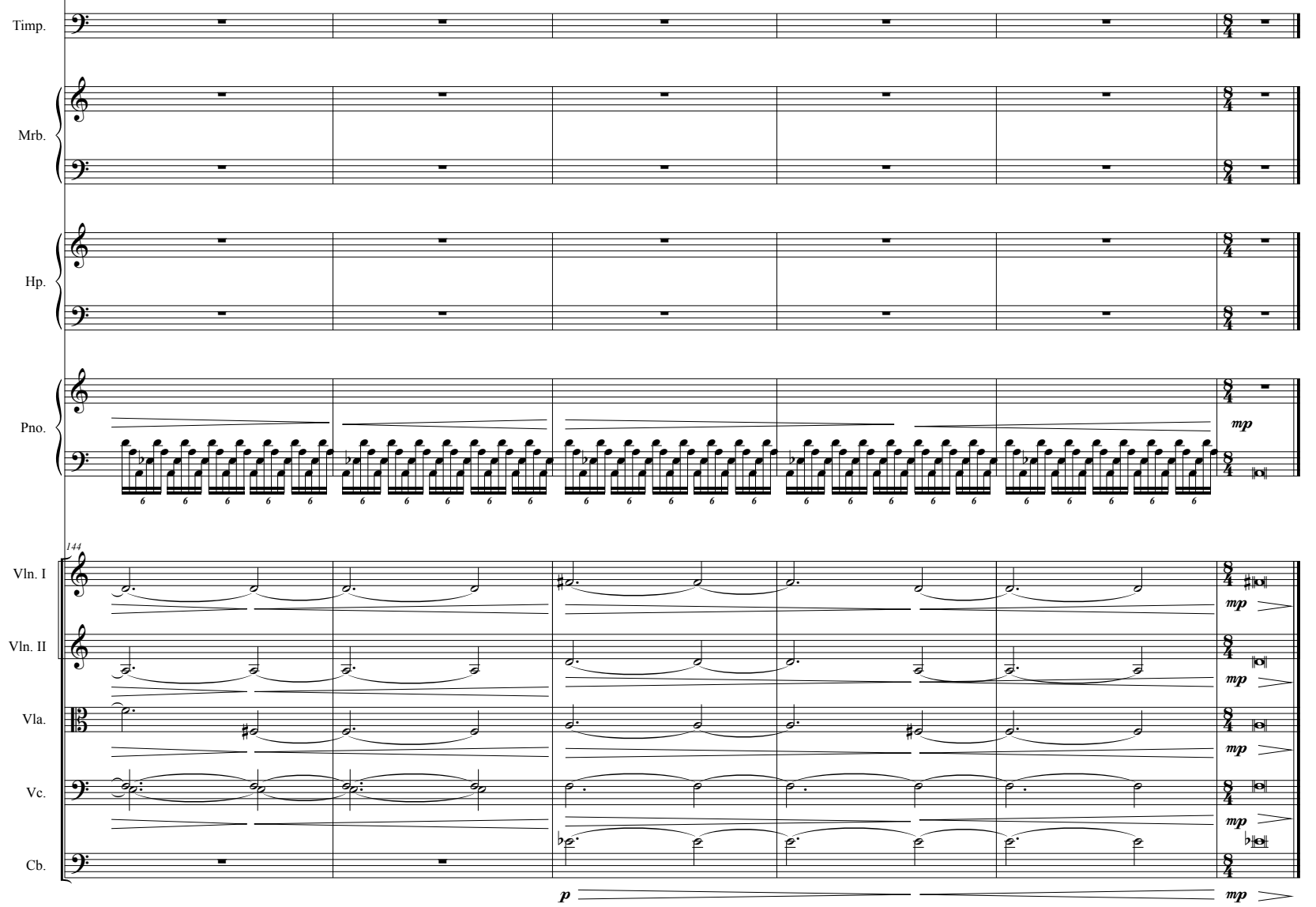